\title{
Safety of Anti-Tumor Necrosis Factor Therapies in Arthritis Patients
}

\author{
Radu M. Nanau ${ }^{1}$ and Manuela G. Neuman ${ }^{1,2}$ \\ ${ }^{1}$ In Vitro Drug Safety and Biotechnology and ${ }^{2}$ Department of Pharmacology and Toxicology, Faculty of Medicine, \\ University of Toronto, Toronto, Ontario, Canada
}

Received, May 1, 2014, Revised, July 15, 2014; Accepted, July 17, 2014; Published, July 30, 2014

\begin{abstract}
Purpose. Inflammatory and rheumatic arthritis remain leading causes of disability worldwide. The arthritis therapeutic area commands the largest market for the prescription of biological and non-steroidal anti-inflammatory drugs (NSAID). Yet biotechnology and pharmaceutical companies conducting research and providing therapeutics in this area frequently face challenges in patient safety. The purpose of our study was to assess safety of anti-tumor necrosis factor therapies in arthritis patients. Methods: The present study systematically reviews adverse events of biologicals alone or in the presence of NSAIDs and other immunosuppressant therapeutics such as disease-modifying antirheumatic drugs (DMARD). We assessed the rheumatology literature that included clinical trials with anti-tumor necrosis factor (TNF) biologicals and case reports published between 2010 and 2014. Results: Currently approved anti-TNF biologicals in arthritis include the monoclonal antibodies infliximab, adalimumab, certolizumab pegol and golimumab, and the fusion protein etanercept. The most frequently-reported adverse event was infection. We grouped the adverse reactions as immune-mediated, hypersensitivity syndrome reactions including cutaneous and hepatic manifestation, neurological, hematological, and malignancy. Discussion: Most adverse events are due to the failure of host immunological control, which involves susceptibility to the drug itself, or de novo infection or reactivation of a latent bacterial or viral infection, often with a different expression of disease. Drug-induced liver injury associated with anti-TNF biologicals must be kept in mind when evaluating patients with increased liver enzymes. Conclusion: Risk assessment in individuals undergoing treatment with biologicals represents a step towards achieving a personalized medicine approach to identify those patients that will safely benefit from this therapeutic approach. Patients and physicians must be alert of anti-TNF agents as potential causes of druginduced liver injury and monitor the therapies. Personalizing therapeutic pharmacovigilance promises to optimize benefits while minimizing side effects.
\end{abstract}

This article is open to POST-PUBLICATION REVIEW. Registered readers (see "For Readers") may comment by clicking on ABSTRACT on the issue's contents page.

\author{
ABBREVIATIONS \\ ADA - anti-drug antibody \\ AE - adverse event \\ ADM - adalimumab \\ ALP - alkaline phosphatase \\ ALT - alanine aminotransferase \\ ANA - antinuclear antibody \\ anti-dsDNA - anti-double-stranded DNA antibody \\ AST - aspartate aminotransferase \\ AS - ankylosing spondylitis \\ CNS - central nervous system \\ CSF - cerebrospinal fluid \\ CZP - certolizumab pegol \\ DILI - drug-induced liver injury \\ DMARD - disease-modifying anti-rheumatic drug \\ ETN - etanercept \\ $\gamma$-GTP - $\gamma$-glutamyl transpeptidase \\ GLM - golimumab \\ HBV - hepatitis B virus
}

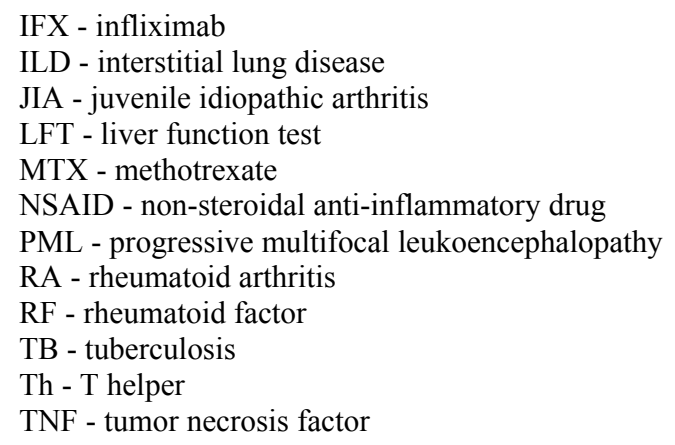
Correspondence Author: Manuela Neuman PhD, Asst. Professor of Pharmacology, Biophysics and Associated International Health, Department of Pharmacology and Toxicology, In Vitro Drug Safety and Biotechnology, Banting Institute, 100 College Street, Lab 217, Toronto, ON, CANADA, M5G 1L7 Tel: 416-398-4880
Email: manuela.neuman@utoronto.ca




\section{INTRODUCTION}

The intracellular destruction of pathogens by phagocytes provides the first line of defense against bacterial and viral infections. The apoptosis of phagocytic macrophages induces pro-inflammatory cytokines, leukotriene and prostaglandins that localize the infection at the site of entry. The attraction of leukocytes to tissues is essential for inflammation. The process is controlled by chemokines, which have an important role in the pathophysiology of inflammatory diseases. Tumor necrosis factor (TNF)- $\alpha$ is a pivotal cytokine that acts upon both the innate and the adaptive immune systems (1-3). At the same time, cytokines and chemokines represent potential targets for therapy. Cytokine technology uses human receptor elements linked to functional proteins to create potent soluble inhibitors of cytokine function.

There is a multitude of potential drug targets in the human autoimmune diseases field, which creates a great opportunity to reverse or prevent inflammation-induced tissue damage. Exposure to anti-TNF therapeutics impairs the production of $\mathrm{T}$ helper (Th) 1 cytokines. In patients with rheumatoid arthritis (RA), therapeutic intervention with antiTNF biologicals restores the low proliferative responses of peripheral blood mononuclear to mitogens, thus suggesting reversibility of this process. Treatment with anti-TNF biologicals in RA led to accumulation of Th1 $\mathrm{CD}^{+} \mathrm{T}$ cells in peripheral blood (4). Occasionally, treatment with anti-TNF biologicals in RA increased peripheral $\mathrm{T}$ cell reactivity to several microbial antigens with a significant increase in the production of interferon (5). In inflammatory rheumatic diseases, the proinflammatory effects of cytokines lead to inflammation, while the anti-inflammatory effects of biologicals at the level of the cartilage and osteocytes re-establish the balance between the proand anti-inflammatory messages. At the same time, there is a significant need for rapid target validation and post-market pharmacovigilance studies.

Clinically, TNF- $\alpha$ inhibitors have shown efficacy in inflammatory and autoimmune disorders. However, by increasing the reactivity of peripheral $\mathrm{T}$ cells to specific antigens, TNF- $\alpha$ also stimulates the antimicrobial defense mechanism (6). TNF- $\alpha$ is a key cytokine in the defense system against infectious diseases, and the efficacy of TNF- $\alpha$ inhibitors is paralleled by susceptibility to a variety of infections (7-9). Most reports to date have described increased susceptibility to intracellular pathogens in patients with underlying chronic infections. TNF- $\alpha$-mediated pathways regulate the molecular interactions between cellular and viral factors within cells. Failure of host immunological control involves reactivation of latent infections. Nonetheless, TNF- $\alpha$ inhibitors have displayed a reasonable safety profile in the setting of some chronic viral infections, and in certain circumstances have demonstrated adjunctive activity in the treatment of these infections. Given the high prevalence of chronic viral infections in patients who are candidates for anti-TNF therapy and the potential for these agents in the treatment of chronic illness, additional studies are needed to assess the risks and benefits of such therapy in the individuals exposed to biologicals. While clinical trials of biologicals in RA note only slight infections, post-marketing analysis has clearly demonstrated an increased susceptibility to infections, especially those caused by Mycobacterium tuberculosis (8).

The aims of this review are to discuss adverse events (AE) in patients with RA, ankylosing spondylitis (AS) and juvenile idiopathic arthritis (JIA) treated with one of the four anti-TNF monoclonal antibodies infliximab (IFX, Remicade ${ }^{\circledR}$, Janssen Biotech, Inc.), adalimumab (ADM, Humira ${ }^{\circledR}$, AbbVie, Inc.), certolizumab pegol (CZP, Cimzia ${ }^{\circ}$, UCB, Inc.) golimumab (GLM, Simponi ${ }^{\circledR}$, Janssen Biotech, Inc.), or the fusion protein etanercept (ETN, Enbrel ${ }^{\circledR}$, Amgen, Inc.). AEs discussed include infections, infusionrelated reactions, immune-mediated reactions, autoimmune AEs, hematological AEs, neurological AEs, as well as adverse drug reactions affecting the liver and the lungs. The association between cancer and anti-TNF biologicals in patients with immunemediated inflammatory arthritis is also presented.

\section{MATERIALS AND METHODS}

The present study systematically reviews adverse events of biologicals alone or in the presence of NSAIDs and other immunosuppressant therapeutics such as DMARDs. We carried out a comprehensive search on Medline. We used Ovid and PubMed mesh database. Additionally, we assessed the rheumatology literature that included clinical trials with anti-TNF biologicals and case reports 
published between 2010 and 2014.

Incidence rates of AEs are compiled from data reported in clinical trials of individuals with RA, AS or JIA using the terms "infliximab", "adalimumab", "etanercept", "certolizumab" or "golimumab," and "clinical trial". Further searches were performed for each section separately in order to get a more detailed picture of the AEs under investigation, using terms such as "infection," "hypersensitivity", "anaphylaxis", "cutaneous", "allergy", "lupus", "autoimmune," "rash," "neurological", "neuropathy", "demyelinating," "progressive multifocal leukoencephalopathy," "cytopenia", "anemia", "leukopenia", "neutronpenia", "thrombocytopenia", "granulocytopenia," "pancytopenia," "lung", "respiratory", "interstitial," "pulmonary," "liver failure," "hepatotoxicity," "hepatitis," "cardiac failure," "malignancy," "cancer" or "neoplasm," along with the name of each drug. Inclusion criteria were studies performed in human patients with rheumatic conditions treated with anti-TNF agents published between 2010present. Nevertheless, there are limitations in the interpretation, since data collection by various centers may introduce great variability in the outcomes. Moreover, there is patient heterogeneity depending on the inclusion/exclusion criteria of the study, as well as, the variants taken into analysis or the aim of the study. An additional source of variability is the statistical methods used especially in clinical trials. Thus, the data interpretation differs from one publication to the other.

\section{Adverse Events}

The rate of AEs in patients with inflammatory arthritis treated with anti-TNF biologicals in placebo-controlled clinical trials are shown in Table 1. Different treatment regimens included anti-TNF biologicals or the DMARD like methotrexate (MTX), in combination with placebo or with one another. The main AEs of IFX were infections, infusion reactions and abnormalities in hepatic enzymes levels, while the presence of anti-drug antibodies (ADA) and autoantibodies like antinuclear antibodies (ANA) and anti-doublestranded DNA (anti-dsDNA) antibodies was associated with a loss of efficacy and a higher risk of AEs. Incidence of AEs were similar between IFX and placebo in patients co-treated with MTX, with a trend towards higher incidences of infections and infusion reactions between IFX monotherapy and placebo (10-15). For ETN, the main AEs were infections, abnormalities in hepatic enzymes levels, neutropenia and infusion reactions. The rates of AEs were similar between patients treated with ETN or with MTX. Infusion reactions occurred more frequently during ETN injections compared to placebo injections (16-19). The main AEs of ADM were infections and infusion reactions. The incidence of infusion reactions was higher for ADM than placebo (20). Rates of serious AEs were low in CZP patients. A trend towards higher odds of developing serious AEs was noted for CZP compared to placebo, primarily due to higher odds of serious infections, regardless of MTX cotreatment (21-23). A dose-dependent trend towards higher rates of AEs was observed in patients treated with GLM, owing particularly to higher rates of infusion reactions and serious infections (24-26). These were consistent with the warnings included in the product information of the drugs (27-31).

\section{Infections}

Anti-TNF biologicals are recognized as risk factors for serious infections (27-31). Anti-TNF biologicals (especially IFX and ADM) are disproportionately associated with infections in the French research axed on tolerance of biotherapies registry and the Portuguese spontaneous reporting database $(32,33)$. In RA cohorts specifically, IFX use was a risk factor for opportunistic infections compared to ETN and MTX (32, 34). Concomitant immunosuppressant treatment, especially steroids, represents an additional risk factor for opportunistic infections among patient receiving anti-TNF treatment $(32,34)$.

While similar patterns were reported in these studies, the individual odds ratios of developing infections varied, as they included patients of different ethnic backgrounds from different areas of the world, patients with RA exclusively or patients with any condition treated by anti-TNF biologicals, as well as different treatment regimens depending on dose, frequency or physician preference. Adherence to several guidelines can help lead to a safer anti-TNF treatment course (35). These include screening for active or latent tuberculosis (TB), as well as vaccination against hepatitis B virus (HBV), varicella zoster virus, annual influenza, and human papilloma virus in young females. Opportunistic 
bacterial and fungal infections have been documented, some with serious AEs (35).

\section{Tuberculosis}

Reactivation of latent TB or de novo TB infection is one of the most important infectious AEs in patients treated with anti-TNF biologicals. In patients, treatment with anti-TNF biologicals (IFX, ADM or ETN) increased the risk of developing TB compared to the general population (36-38). Rates of TB were also higher in RA patients not exposed to anti-TNF treatment compared to the general population (38). Among patients treated with antiTNF biologicals, IFX and ADM carry risks similar to one another, while monoclonal antibodies are associated with higher odds of developing TB than $\operatorname{ETN}(39,40)$.

As over one third of the world population may carry latent TB infection which can lead to active disease, especially under conditions of immunosuppression, it is important to detect and treat this infection prior to commencing anti-TNF treatment $(41,42)$. Guidelines for TB screening in future anti-TNF patients include detailed clinical history, physical examination, chest radiograph, and a tuberculin skin test (43). Exposure to anti-TNF biologicals increased the risk of developing active TB in a Taiwanese RA sample with a low incidence of TB screening (44). In contrast, screening excluded TB with a high degree of certainty (sensitivity 0.83 , specificity 0.74 , positive predictive value 0.29 and negative predictive value 0.97) in a small sample of patients with inflammatory rheumatic diseases treated with antiTNF biologicals in an area with a high endemic rate (45). Among patients born in regions with low endemic TB rates, being a healthcare worker might be a risk factor of contacting the disease (46). De novo contamination was also observed in patients receiving anti-TNF treatment when coming into contact with infected individuals or traveling to regions with high endemic rates (47).

\section{Non-tuberculosis Bacteria and Fungi}

Non-TB bacterial infections include non-TB mycobacteriosis, listeriosis, legionellosis, staphylococcemia, salmonellosis, nocardiosis and pneumocystosis, with presentations including cutaneous manifestations, pulmonary presentation (predominantly pneumonia) and neurological manifestations (predominantly meningitis). Anti-
TNF biologicals were risk factors for non-TB mycobacterial diseases compared to both RA patients not treated with these agents and to the general population. IFX and ADM were risk factors compared to ETN. RA was a risk factor among nonusers of anti-TNF biologicals compared to the general population, while older age and RA were risk factors for non-TB mycobacterial disease among anti-TNF users (38). Treatment with antiTNF biologicals is a risk factor for cutaneous infections. Skin infections generally only have cutaneous manifestations, but may also present systemic features such as fever (48).

The risks of developing Legionella pneumophila or Listeria monocytogenes infections were also higher among anti-TNF treated patients compared to the general population in European samples $(36,49,50)$, while IFX or ADM use was a risk factor for legionellosis compared to ETN (50).

Fungal infections include pneumocystosis, histoplasmosis, aspergillosis, cryptococcosis, candidiasis, actinomycosis, blastomycosis and coccidioidosis, with predominantly pulmonary presentation. In a comprehensive review of the MEDLINE and PubMed databases, invasive fungal infections associated with IFX occurred after a median 55 days and a median 3 infusions after initiating treatment, while occurring after a median 144 days in ETN patients. Invasive fungal infections in anti-TNF patients were lethal in $32.2 \%$ of the cases in which outcome was available (51).

Pneumocystis jirovecii colonization was detected in $25.6 \%$ of RA, AS and psoriatic arthritis patients treated with anti-TNF biologicals, of which half occurred with IFX. Risk factors include corticosteroids use, MTX use and IFX duration of $>3$ years (52). The onset of Pneumocystis pneumonia in the Food and Drug Administration Adverse Event Reporting System database occurred after a mean $21 \pm 18$ days since starting IFX, and after a mean $2.1 \pm 1.3$ IFX infusions. Pneumocystis pneumonia resulted in death in $27.4 \%$ of these cases (53). IFX was also a risk factor for coccidioidomycosis in a sample of inflammatory arthritis patients. The cumulative incidence of coccidioidomycosis in this sample was $1.1 \%(2.8 \%$ among IFX patients and $0.5 \%$ among patients receiving other medications) (54).

\section{Viruses}

Viral infections include HBV, cytomegalivirus, 
varicella zoster virus, herpes simplex virus, EpsteinBarr virus, and John Cunningham virus. In these cases, the affected organs are those in which the virus proliferates predominantly. Viruses are the predominant infections in pediatric and adolescent JIA patients, suggesting likely childhood diseases such as infections by members of the herpes virus family (55).

The main concern regarding viral infections in anti-TNF patients is infections and reactivation of HBV. As such, anti-TNF biologicals should be avoided in chronic HBV infection, classified as positive by the presence of HBV surface antigen, and in resolved $\mathrm{HBV}$ infection, classified as positive by the presence of anti-HBV core and/or anti-HBV surface antibodies (56). Treatment with anti-TNF was a risk factor for HBV seroconversion in a sample of RA patients (57). ADM was associated with a low HBV risk in an RA population, which could mean either that ADM suppresses HBV reactivation, or that ADM is not used out of concern in individuals with a high risk of HBV infection (58). While a diagnosis of RA was a risk factor for slightly elevated aspartate aminotransferase (AST) and alanine aminotransferase (ALT) in an RA sample with preexisting HBV infection, these did not exceed the upper limit of normal (59). Viral reactivation was not observed in small samples of RA patients with resolved HBV infection treated with anti-TNF agents $(60,61)$.

Monoclonal antibodies were risk factors for varicella zoster virus infections compared to ETN (62). IFX or ETN were not risk factors for EpsteinBarr viremia in peripheral blood mononuclear cells in RA patients. Instead, a positive correlation was observed between Epstein-Barr viral load and disease activity in RA patients (63).

\section{Parasites}

The main parasitic infection is leishmaniasis (Leishmania sp.), which generally includes visceral or cutaneous presentation. Also infection with Strongyloides stercoralis with pulmonary and gastrointestinal symptoms are described (32).

\section{Infusion Reactions}

Anti-TNF biologicals are disproportionately
associated with general disorders and
administration site conditions in the Portuguese

spontaneous reporting database (33). Infusion reactions accounted for 257 of 920 (27.9\%) cutaneous AEs reported in a large sample of patients with chronic inflammatory rheumatic conditions treated with IFX, ADM or ETN, including erythema, urticaria, eczema or rash, which can be accompanied by pain and swelling. Such reactions occur with all anti-TNF biologicals, primarily in the first month of treatment $(48,64)$.

Monoclonal antibodies are structurally immunonegenic as they contain sections that can be recognized by the immune system as non-self epitopes, leading to the production of specific ADAs (65). The presence of IgE ADAs was associated with acute infusion reactions in IFX patients (66). Anaphylaxis is an example of acute infusion reaction. The most commonly accepted mechanism of anaphylaxis reaction involves IgEmediated type I acute hypersensitivity. This hypersensitivity reaction is characterized by the release of mediators from mast cells, basophils and recruited inflammatory cells. Symptoms of anaphylaxis can occur between a few minutes to a few hours after exposure to the drug, and can include any combination of cutaneous, cardiovascular, respiratory distress, laryngeal edema and severe bronchospasm, gastrointestinal and neurologic/muscular symptoms, and severe hypotension $(65,67,68)$.

IgE ADAs were also significantly associated with positive skin tests results in patients with previous immediate hypersensitivity reaction to IFX. In turn, skin tests positivity was also associated with early and severe reactions. These results support the hypothesis that infusion reactions to IFX are IgE-mediated, while skin tests with IFX preparations provide a predictive tool for these AEs $(69,70)$. This was demonstrated in a study in which positive skin tests were reported in all cases of urticaria and in 5 of 8 cases of anaphylaxis. The remaining 3 of 8 cases of anaphylaxis occurred at the first dose, suggesting non-IgE anaphylaxis (69). These are also known as anaphylactoid reactions. Anaphylactoid reactions have symptoms similar to anaphylaxis reactions, but occur in an IgE-independent manner $(65,67)$.

An overall rate of acute infusion reactions of $5.8 \%$ was observed in a retrospective analysis of 135 RA patients treated with IFX over a 9 years period (71). In this study, most infusion reactions were mild or moderate in intensity, and most 
occurred early during IFX treatment. The areas most commonly affected by acute infusion reactions were the neck and the head, followed by the skin. The most common of these were pruritis, headache, facial flushing and chest tightness (71). The most common delayed infusion reactions, occurring 1-14 days post-infusion, were moderate in severity, and included chest/respiratory symptoms, general manifestations and skin manifestations. These occurred after a mean 7.2 days. Most delayed infusion reactions also occurred during the early phases of treatment (71).

Risk factors for acute hypersensitivity reactions in patients treated with anti-TNF monoclonal antibodies include patient-specific factors such as disease, atopic phenotype and concomitant use of immunosuppressants, as well as drug-specific factors such as dose, duration, number of infusions and route of administration. The highest rate of IFX infusion reactions was found in RA patients, suggesting that infusion reactions may be, at least in part, mediated by the same mechanisms as the disease itself. While immunosuppressants may help limit the development of ADAs and thus of infusion reactions, the role of prophylaxis with acetaminophen and antihistamines is less clear. The dose and frequency of IFX administration are closely related to ADAs formation, and thus with infusion reactions, as ADAs develop primarily in patients receiving lower doses or intermittent treatment $(65,67)$.

Infusion reactions are detailed in Table 2. Drug intolerance with cutaneous manifestations and swelling, and occasionally dyspnea and tachycardia, are reported in several patients with infusion reactions (72-81). Cardiopulmonary arrest accompanied a case of severe IFX anaphylaxis (82). Allergic hypereosinophilia is described elsewhere (83).

Desensitization was performed in a series of patients with clinically-observed hypersensitivity reactions to anti-TNF biologicals and positive skin tests. A standard 12-step protocol was used for desensitization, involving the administration of increasing doses at 15 min intervals. Manifestations occurring during desensitization were less frequent and less severe in nature. In cases in which hypersensitivity occurred during desensitization, patient-specific modifications were made to the protocol, usually involving the administration of antihistamines, and the protocol was repeated (68). ADM desensitization was performed using gradually increasing doses ranging from 5 to $15 \mathrm{mg}$ at a time. Dose escalations occurred every $30 \mathrm{~min}$, for a cumulative dose of $40 \mathrm{mg}$. The $40 \mathrm{mg}$ were administered quicker using larger doses during subsequent infusions, and ADM was accompanied by antihistamines and antileukotrienes during the first 4 treatment sessions (79).

\section{Immune System Disorders}

Immune system disorders encompass AEs in which the immune system overreacts to non-threatening foreign substances or against the body's own tissues. Anti-TNF biologicals are disproportionately associated with immune system disorders (33). Anti-TNF biologicals are associated with autoimmune disorders, particularly cutaneous disorders, drug-induced psoriasis, inflammatory bowel disease and autoimmune hepatitis $(64,84$, $85)$. Immune system disorders described in recent case reports are detailed in Table 3.

\section{Immune-mediated Reactions}

Immune-mediated reactions include lichenoid eruptions, in which infiltration between the epidermis and dermis was shown by biopsy (86-88), vasculitis $(87,89-93)$, a case of recurrent subacute prurigo with eosinophilia is also described (94), a case of Stevens-Johnson syndrome characterized by abdominal desquamation (95), a case of pustular dermatitis (96), dermatomyositis (97, 98), and a case of morphea (99).

\section{Autoimmune Adverse Events}

Lupus-like syndrome is a common autoimmune AE. The incidence of lupus-like syndrome was $1.75 \%$ in a small sample of spondyloarthritis patients treated with IFX, ADM or ETN (100). Specifically, the incidence of IFX-induced systemic lupus erythematosus was $1.3 \%$ in a recent systematic review (101). A high incidence of autoantibodies including ANAs, anti-dsDNA antibodies, anticardiolipin antibodies, anti-histone antibodies, anti-nucleosome antibodies and antineutrophil cytoplasmic antibodies positivity was noted in these patients $(100,101)$. Several recent case reports describe drug-induced lupus in patients treated with anti-TNF biologicals (102-112). While manifestations were varied, a common feature was 
the presence of autoantibodies. Levels of autoantibodies decreased after discontinuation of anti-TNF biologicals in most patients, and even returned to normal in some (102). Autoantibodies were negative in a patient diagnosed with discoid lupus erythematosus (112).

The first step in the treatment of drug-induced systemic lupus erythematosus is the discontinuation of the offending drug, while treatment with corticosteroids and immunosuppressive agents may be required to achieve full symptoms resolution (113). The pathogenesis of systemic lupus erythematosus is believed to involve a shift from Th1 cytokines towards Th2 cytokines, brought about by TNF- $\alpha$ inhibition with anti-TNF biologicals. This cytokines shift is then thought to bring about the production of autoantibodies and the development of systemic lupus erythematosus. Alternatively, TNF- $\alpha$ inhibition prevents apoptosis through decreased CD44 production, preventing the clearance of nuclear debris and apoptotic neutrophils, and thus promoting the production of antibodies against DNA and nuclear components (113).

Another common autoimmune AE of antiTNF biologicals is drug-induced psoriasis. This was recently described in a review of the literature and of the French pharmacovigilance database. The majority of cases involved pustular lesions. The most commonly affected sites were the palms and/or soles. All of IFX, ADM and ETN were involved, with IFX accounting for more cases than the other two drugs. Recurrence of psoriasis can occur at the same location as the initial reaction or at a different site. It can further occur with a different anti-TNF biological (114).

Ten cases of psoriasiform eruptions are described in patients with inflammatory arthritis (RA and spondylo-arthropathy) treated with ETN or ADM. The condition presented pustular, plaque or guttate morphology. Plantar plaques or pustules are described in 4 of $10 \quad(40.0 \%)$ cases. Nail involvement was not observed. Topical treatment was provided in 4 of $10(40.0 \%)$ cases. The initial anti-TNF biological was interrupted in 8 of 10 $(80.0 \%)$ cases. Among these, switching to a different anti-TNF biological led to either no improvement or only partial improvement. Further stopping anti-TNF biologicals led to complete symptoms resolution, or at least partial improvement of psoriasiform eruptions. Partial improvement was obtained with topical ointments without modifying treatment in the remaining 2 of $10(20.0 \%)$ cases (115). Psoriasis lesions are also described in several recent case reports $(87,107$, 116-121).

Autoimmune AEs with cutaneous manifestations also included intermediate bullous and cicatricial pemphigoid (122) and granuloma annulare (123). Other autoimmune AEs in patients treated with anti-TNF biologicals included de novo or exacerbation of autoimmune hepatitis (124-128) and antiphospholipid syndrome $(129,130)$. IFX is believed to lead to the unmasking of autoimmune hepatitis by binding to transmembrane TNF on the cell surface, thus inducing apoptosis and leading to the release of nucleosomes (131).

\section{Neurological Adverse Events}

The majority of neurological AEs reported in relation to IFX, ADM, CZP or ETN in the Food and Drug Administration Adverse Event Reporting System occurred in RA patients, with 393 of 772 $(50.9 \%)$ events over a 10 years period. ETN and IFX were associated with the majority of these events (132). In RA patients specifically, the most common neurological AEs were central nervous system (CNS)/spinal demyelination, optic neuritis, peripheral neuropathy and facial palsy, with low incidences of transverse myelitis, leukoencephalopathy, other demyelinating disease, cerebrovascular disease, encephalopathy and CNS infections (132). Neurological adverse events are described in Table 4.

Among 33 reports of demyelinating disorders in French patients with rheumatic diseases treated with anti-TNF biologicals over a 3 years period, IFX was used in $15(45.4 \%)$ patients, ETN in 12 (36.4\%) and ADM in 6 (18.2\%). Two thirds of these cases involved the CNS (encephalic involvement, transverse myelitis, optic neuritis) and one third the peripheral nervous system (chronic inflammatory demyelinating poly-radiculoneuropathy, Guillain-Barré syndrome). Cerebrospinal fluid analysis revealed raised protein levels in 4 patients, immunoglobulin oligoclonal bands in 11 and/or pleiocytosis in 4, while it was normal in 6 patients with CNS involvement. Cerebrospinal fluid analysis showed raised protein levels in 9 of $10(90.0 \%)$ of patients with peripheral nervous system involvement in which analysis was 
performed (133). White matter lesions were common findings on magnetic resonance imaging in patients with CNS involvement. Anti-TNF biologicals were discontinued in all patients with CNS involvement and in $10(90.9 \%)$ patients with peripheral nervous system involvement. Treatment with glucocorticoids was initiated in $15(68.2 \%)$ and complete resolution was noted in $12(54.5 \%)$, with partial resolution in $8(36.4 \%)$ and no changes in the remaining 2 patients $(9.1 \%)$ with CNS involvement. Intravenous immunoglobulins were administered in 8 patients, with $2(25.0 \%)$ complete and $6(75.0 \%)$ partial recoveries in patients with peripheral nervous system involvement. The remaining 2 patients did not receive any treatment, with neurological symptoms remaining either stable or improving. The anti-TNF treatment was continued in one patient, with neurological symptoms remaining stable. Two $(25.0 \%)$ of the patients treated with intravenous immunoglobulins relapsed, one upon introduction of ADM and one without any subsequent anti-TNF treatment (133). Demyelination events occurred in 3 patients treated with GLM $100 \mathrm{mg}$ for rheumatological indications in a large clinical trial. The incidence of demyelination events in GLM was 0.12 per 100 patient-years (134).

Demyelinating diseases are detailed in a few patients (135-137). CNS demyelination evolved to multiple sclerosis in two patients (138), with newonset multiple sclerosis in another patient (139). Neuropathy with various presentations (140-143), myelitis $(142,144)$ and neuritis $(142,145,146)$ are described elsewhere. A case of tumefactive demyelinating lesions is also presented (147). Encephalopathy is described in several patients (142, 148-150).

Progressive multifocal leuko-encephalopathy (PML) is a subacute CNS infection associated with the destruction of oligo-dendrocytes by John Cunningham virus. John Cunningham virus reactivation occurs under conditions of immunosuppression. Symptoms include confusion, motor impairment, impaired coordination, speech disorders and visual disturbances, while seizures are uncommon. Demyelinated areas are visible in the parietal and occipital regions. Diagnostic confirmation is usually obtained by identification of John Cunningham virus in cerebrospinal fluid or by brain biopsy $(151,152)$. The incidence of PML is low, and it is comparable between the general population and RA patients (152). A total of 34 PML cases were confirmed among autoimmune rheumatic diseases patients in the Food and Drug Administration Adverse Event Reporting System database. Among these, 15 patients were exposed to biological agents and 19 patients were exposed to other anti-inflammatory agents such as azathioprine, cyclosporin $\mathrm{A}$ and prednisone equivalents. One case is reported in an RA patient treated with IFX (153). IFX and ADM have been associated with PML in a recent review of the Canada Vigilance and World Health Organization adverse event databases (154). Two recent cases of PML are described $(155,156)$. A case of encephalitis associated with Epstein-Barr virus infection is also reported (129).

\section{Hematological Adverse Events}

Hematological AEs are important safety considerations of anti-TNF biologicals. Cytopenia describes a condition marked by a reduction in the number of blood cells, and it can include anemia, leukopenia, neutropenia, thrombocytopenia, granulocytopenia or pancytopenia. Transient neutropenia (neutrophil count $<1.50 \times 10^{9} / \mathrm{L}$ ) is the predominant non-malignant hematological complication in patients treated with anti-TNF biologicals. Risk factors include a history of neutropenia on other medications or a low baseline neutrophil count. However, neutropenia can develop without co-medication as well. ETN was the biological most often associated with this hematological complication, and consequently most cases were reported in RA patients (157). Hematological adverse events in recent case reports are detailed in Table 5.

Neutropenia is described in 5 RA patients treated with ETN (158). In two patients, neutrophil counts dropped from baseline until they reached a low but stable level during treatment. ETN was continued and the patients are being monitored. A third patient experienced a significant drop in the neutrophil count while on ETN. A rebound in the neutrophil count to a low but stable level was observed upon ETN discontinuation and a switch to ADM. Mild neutropenia is described in a patient treated with ETN plus MTX. ETN was well tolerated after gradual MTX discontinuation. Neutropenia occurred in a fifth ETN patient, and any attempt to re-introduce ETN failed due to 
recurrent neutropenia (158). Neutropenia is also detailed in several case reports in which neutrophil counts improved following discontinuation of antiTNF biologicals (159-161). Two patients had a history of neutropenia while receiving DMARDs, therefore the influence of co-medication such as MTX cannot be discounted (159). Another patient had no history of abnormal hematological parameters during MTX treatment (161).

Leukopenia is described in two patients treated with ETN and DMARDs. No improvement in the leukocytes count was achieved when the DMARDs were discontinued, but leukocyte levels normalized when ETN was discontinued $(162,163)$.

In a recent review, thrombocytopenia (platelet count $<150 \times 10^{9} / \mathrm{L}$ ) was observed predominantly in anti-TNF patients without comedication, thus suggesting that this hematological complication is likely a consequence of these biologicals. IFX and ETN were associated with thrombocytopenia (157). Thrombocytopenia is described in two patients. Platelet counts rebounded soon after discontinuation of anti-TNF biologicals (164).

Lymphocytosis followed by neutropenia is described in a patient treated with ADM plus MTX. Discontinuation of MTX led to resolution of lymphocytosis, while neutropenia also resolved soon after ADM discontinuation. Therefore, ADM was only responsible for neutropenia in this patient (165).

Anti-TNF biologicals such as IFX, ADM and GLM improve anemia in RA and AS patients. On the other hand, ETN has no significant effects on hemoglobin levels $(166,167)$.

Pancytopenia is described in two patients treated with ETN plus MTX $(168,169)$. One of the patients developed severe multilobar pneumonia, although a pathogenic organism could not be definitively identified, likely due to prophylactic antibiotic treatment. The patient died of multi-organ failure resulting from septic shock of respiratory (169). Pancytopenia associated with hemophagocytic syndrome complicated a case of drug-induced lupus (170).

\section{Adverse Events Affecting Other Organs}

Adverse events affecting other organs in recent case reports are detailed in Table 6.

\section{Lung Disease}

Anti-TNF biologicals are further associated with respiratory, thoracic and mediastinal disorders (33). Interstitial lung disease (ILD) describes a large group of pulmonary conditions associated with inflammation and fibrosis. Non-infective respiratory, thoracic and mediastinal disorders are reported in 8 of $201(4.0 \%)$ patients with longstanding RA treated with ADM (171). The incidence of ILD was $0.6 \%$ in a large postmarketing surveillance sample of RA patients treated with ETN (172). Treatment with anti-TNF biologicals (IFX, ADM and ETN) is thus a risk for the development of ILD in RA patients. RA itself and MTX co-treatment represent additional risk factors for ILD, while age $\geq 65$ years, a history of ILD, and concomitant immunosuppressants are risk factors for fatal ILD in RA patients (173-175). Cases of ILD in CZP-treated patients have also been recently described, while serious noninfectious pulmonary AEs are reported in clinical trials in RA patients receiving GLM in the presence of MTX only (176). Lung biopsies are often needed to confirm ILD (175). The most common classifications of ILD were interstitial pneumonia, nonspecific interstitial pneumonia, organizing pneumonia, diffuse alveolar damage and lymphoid interstitial pneumonia (175).

ILD is described in 3 patients (177-179). Progressive resolution of symptoms occurred in a patient treated with prednisone (179), while little recovery was observed in two patients upon treatment with methylprednisolone $(177,178)$. Differences could be explained by more extensive affected areas in the latter two patients, who were also older $(177,178)$. In another study, exposure to ETN led to exacerbation of the condition in a patient with a history of ILD (180).

Upon CZP exposure, a patient with a previous episode of pneumonitis while on MTX treatment developed fatal fibrosing alveolitis with respiratory failure (181). Diffuse alveolar hemorrhage is described in two patients $(182,183)$. Interstitial pneumonia (184-187) and acute pneumonitis $(188,189)$ were diagnosed elsewhere. Interstitial pneumonia was fatal in an elderly patient with a history of ILD treated with ETN (187). Lupus occurred in the presence of organizing pneumonia in another patient (190). 


\section{Hepatitis}

Hepatic AEs in patients treated with anti-TNF biologicals are usually classified as infectious AEs, as they result from reactivation of viral hepatitis B. Alternatively, anti-TNF biologicals may also uncover autoimmune hepatitis, while instance of symptomatic, severe acute hepatitis are rare (191). Ghabril et al. (192) identified a total of 34 cases of drug-induced liver injury (DILI) associated with the use of TNF- $\alpha$ antagonists between 2003 and 2011 (26 IFX, 4 ETN and 4 ADM).

The incidence of elevations in ALT and AST over the upper limit of normal occurred in $5.9 \%$ of RA patients in a large sample treated with IFX, ADM or ETN (193). IFX, ADM and to a certain degree ETN were risk factors for ALT and AST elevations $>2$ times over the upper limit of normal compared with DMARDs (193, 194). Asymptomatic AST and ALT elevations $>10$ times over the upper limit of normal were observed in a patient treated with ETN plus MTX. Liver function test results normalized after ETN interruption, but recurred with ADM. IFX was well tolerated despite persistently positive ANA (195).

Acute hepatitis with positive ANA and antidsDNA antibodies is reported in two patients. DILI was diagnosed in both patients as features of autoimmune hepatitis or sclerosing cholangitis were absent in biopsy, despite persistently high autoantibodies $(196,197)$.

\section{Sarcoidosis}

Sarcoidosis is a granulomatous disorder that can affect multiple organs. Neurosarcoidosis is described in an RA patient treated with ETN (198). The mechanism of neurosarcoidosis is believed to involve the expansion of inflammatory meningitis into the brain parenchyma or into the spinal cord (199). Manifestations of neurosarcoidosis depend on the affected neuroaxis. For example, infiltration of granulomas into leptomeningeal and intraparenchymal structures can lead to cranial nerve palsies, basal meningitis or endocrine dysfunction, the consequences of which may be peripheral neuropathies and sensorimotor polyneuropathy (200). Cases of thoracic and pulmonary sarcoidosis are described elsewhere (201, 202). Additional cases of granulomatous hepatitis and granulomatous interstitial nephritis are also presented $(203,204)$.

\section{Cardiovascular Effects of anti-TNF Biologicals}

Based on data from Medicare and drug benefit programs (1994-2004), the use of anti-TNF biologicals (ETN and IFX) was associated with an increased risk of heart failure compared to MTX in elderly ( $\geq 65$ years) RA patients (205). Both ETN and IFX were risk factors for heart failure in a sample of 2121 younger ( $<50$ years of age) RA patients. The risk with anti-TNF biologicals was comparable to that of DMARDs, which can be attributed in part to a relatively low overall incidence in this younger population (206). Based on this evidence, older age is a risk factor for heart failure in RA patients treated with anti-TNF biologicals. Furthermore, elderly anti-TNF patients were found to have a 4.2-fold higher risk of death from heart failure compared to MTX patients (205). Elsewhere, RA disease activity was the main risk factor for the 3 years incidence of heart failure, and overall anti-TNF biologicals generally shows more beneficial than detrimental effects with respect to the risk of heart failure, owing primarily to the reduction in the inflammatory activity of RA (207, 208). The incidences of tachyarrhythmias and bradyarrhythmias were not different between IFX and placebo in a sample of 75 spondyloarthritis or RA patients (209). Furthermore, anti-TNF biologicals have positive effects on cardiovascular health by improving metabolic parameters, at least in the short term (210).

Cardiovascular AEs are described in a few RA patients treated with IFX and ETN (211-214). Supraventricular tachycardia occurred within 3 hours of the $8^{\text {th }}$ IFX infusion in the first of these patients (211). A significant decrease in cardiac output $(7.04 \pm 2.3$ to $6.12 \pm 2.1 \mathrm{~L} / \mathrm{min})$ and in stroke volume $(91 \pm 29.0$ to $83 \pm 28.8 \mathrm{~mL} /$ beat $)$, with non-significant increases in systolic blood pressure, diastolic blood pressure and total peripheral vascular resistance, also occurred as an infusion reaction in an IFX patient (212). Dilated cardiomyopathy was induced by IFX after 6 months of treatment in the third patient (213). Severe heart failure, reversible upon ETN discontinuation, developed in an AS patient (214).

\section{Relationship between Anti-TNF Biologicals and Cancer}

The relationship between anti-TNF biologicals and cancer is controversial. The following section 
provides a brief analysis of the current knowledge. Anti-TNF biologicals were disproportionately associated with benign, malignant or unspecified neoplasms (33). However, inflammation is a known risk factor for cancer, such that the increased risk of cancer observed in RA cohorts treated with antiTNF agents could be a result of the underlying disease (215).

Overall, the risk of cancer is similar in RA patients treated with anti-TNF biologicals and the general population. Using data from randomized controlled clinical trials, IFX and ADM were associated with an increased risk of malignancies compared to placebo, particularly a non-significant trend towards a higher incidence of lymphomas $(216,217)$. While the risk of lymphoma, particularly Hodgkin's lymphoma, appears increased in RA patients treated with anti-TNF biologicals, patients with RA carry a 2-3-fold higher risk of lymphomas compared to the general population. Risk factors for lymphoma include RA, predominantly in individuals with positive rheumatoid factor $(218,219)$. When adding biologicals to the equation, no increased risk of cancers is usually found between patients exposed to anti-TNF agents or placebo. It is interesting to note that while anti-TNF monoclonal antibodies may be risk factors, no significant differences exist between anti-TNF agents and placebo when IFX, ADM and ETN are considered together. Looking at individual cancers separately and individuals biologicals separately would thus likely offer a more appropriate means to compare anti-TNF and placebo, yet no significant differences are apparent due to the relatively low incidence of these AEs (215).

Using data from 33 placebo-controlled trials, treatment with anti-TNF agents was not associated with an increased risk of cancer compared to placebo in RA patients treated for up to 2 years. A trend towards an increased risk of non-melanoma skin cancers was however observed (220). As such, treatment with anti-TNF biologicals is a risk factor for cutaneous malignancies (64). Skin neoplasms include melanoma, and non-melanoma cancers such as basal cell carcinoma (48). IFX and ETN are associated with non-melanoma skin cancer and with melanoma based on data from the US National Data Bank for Rheumatic Diseases (221). Anti-TNF biologicals were associated with non-melanoma skin cancer in a recent meta-analysis, but not with other types of cancer (222). Overall, these reports suggest that RA patients may be predisposed to higher rates of malignancies than the general population, especially lymphomas, while long-term exposure to biologicals appears safe. An alternative explanation could be that anti-TNF biologicals may cause cancer on their own but may also decrease the risk of cancer associated with the chronic inflammatory environment. Based on current knowledge, no definitive conclusions could be drawn with regards to the risk of cancer in anti-TNF patients, and studies with longer follow-up times may help elucidate the relationship, if any.

\section{DISCUSSION}

The present review discussed AEs in which antiTNF biologicals were incriminated. However, additional factors such as co-medication should be considered when analyzing the causes of AEs. The majority of RA patients that are treated with antiTNF biologicals are also taking NSAIDs as painkillers or as additional therapies.

Several NSAIDs play a prominent role in the history of idiosyncratic hepatotoxicity. For example, diclofenac was shown to produce hepatic injury since the 1980 s. In $15-20 \%$ of patients taking the drug, aminotransferase levels are markedly increased (223- 230). Clinically, acute disease resembles acute viral hepatitis and chronic injury is similar to chronic hepatitis $(227,231)$. At the histological level, the main lesion has been hepatic necrosis. The necrosis is non-zonal although it tends to be more marked in zone 3 . Female gender is a risk factor for hepatotoxicity susceptibility. In addition, patients with osteoarthritis have a significantly higher incidence of hepatic injury than RA patients (230). Most cases have presented with the syndrome of acute hepatitis characterized by jaundice and to a varying degree by fatigue, anorexia, nausea and vomiting. Fever, rash and eosinophilia are uncommon, but were recorded in one report (232). As with other drug-induced hepatocellular injury, massive necrosis with fulminant hepatic failure and death were noted $(230,233)$. Chronic active hepatitis was also described with diclofenac. The mechanism of this reaction was delayed-onset hypersensitivity (234). Rostom et al. (235) reviewed NSAIDs hepatoxicity in randomized controlled trials in arthritis patients. Laine et al. (236) further studied liver injury 
associated with diclofenac in a large sample of arthritis patients in a long-term prospective clinical trial, and concluded that this is not an uncommon AE. Moreover, Pilotto et al. (237) reported NSAIDs-related gastrointestinal bleeding. Diclofenac was associated with hospitalization in a case-crossover study, including peptic ulcer, bleeding and perforation (238).

The major side effects of NSAIDs which are the gastrointestinal complications, renal disturbances and cardiovascular events are presented in the seminal review by Harirfoorosh et al., (239). Arthritis patients using pain killers and NSAIDs are prone to cardiovascular disease (240) and renal damage (241). However, the population treated for RA presents a heterogeneity in patient population in terms of specific disease involvement, and ethnic diversity of the patients. Moreover, age group is an important parameter. The majority of patients are elderly individuals that, in addition to RA, may present another underlying disease (diabetes, hypertension, obesity) that may direct them to ADRs. Also, the type and small number of ADRs, when compared to the general population taking the same medication, make any conclusion regarding the risk of NSAIDs incrimination in interaction with biologicals almost impossible to judge. In many of these studies, the inflammation and inflammatory activators that exist continuously in RA is ignored. The target of both biologicals and NSAIDs is inflammation. This phenomenon is important since inflammation is by itself a risk factor of cardiovascular events. Biologicals and NSAIDs thereby, both should reduce the cause for increase cardiovascular ADRs. However, no study can identify the impact of separate component in an adverse event.

Gastrointestinal complications are frequent during the NSAIDs therapy for RA (239). Several factors including a history of gastric mucosa damage, age over 60 years, previous exposure and ADR to NSAIDs, and/or drug interactions with corticosteroids or anticoagulants increase the risk of developing gastrointestinal side effects. These factors may also influence the interaction between biologicals and NSAID.

Ibuprofen is a widely-used NSAID with antipyretic and analgesic properties that can produce an unpredictable hypersensitivity syndrome reaction likely caused by a combination of metabolic and immunologic factors. Immune- mediated components, such as T cell cytokines and chemokines, can exacerbate cellular responses and create complex pathways that lead to a variety of clinical manifestations including severe cutaneous reaction and of drug-induced liver injury (242-244).

Treatment of RA and related conditions with low doses of MTX may lead to steatosis. MTXinduced fibrosis can appear during treatment. Rarely, cirrhosis was reported $(245,246)$. A case of MTX anaphylaxis allowed ETN to be continued in a patient co-treated with these two agents (247).

One of the most worrisome conditions is DILI. The clinical syndrome of acute liver damage relates, at least in part, to the apparent mechanism of injury. Hepatic injury induced by large single overdose of intrinsically toxic drugs, (e.g., acetaminophen) develops within 24 to 72 hours of intake and usually, is accompanied by renal failure. Regular intake of some toxic drugs (e.g., methotrexate) leads to slowly evolving chronic disease. Liver damage due to hypersensitivity-type of idiosyncrasy to NSAIDs, it is not dosedependent. Usually appears after one to five weeks of taking the drug unless there has been previous exposure and is preceded or accompanied by systemic features that are hallmarks of hypersensitivity (243). Hepatic injury attributable to metabolic idiosyncrasy may appear after weeks to months of taking the drug in the normally prescribed dose and usually presents without the systemic features. Organs other than the liver may be involved in the syndrome of DILI as the result of selective injury or as part of hypersensitivity reaction (244). Regardless of underlying disease, hepatotoxicity of NSAIDs was described in many cases (248).

However, RA per se may be responsible for susceptibility to certain NSAIDs. Patients with JIA and RA appear to be more vulnerable than others, and there is a positive correlation between activity of the underlying disease and susceptibility to the hepatic injury. Hepatic damage induced by aspirin occurs in $50 \%$ or more of patients with high but normal blood levels of the drug ( $>15 \mathrm{mg} / \mathrm{dl})$. This level can be achieved by the dose given in active RA. The injury is intrinsic. Bilirubin levels are normal or slightly elevated and jaundice is noted in less than $5 \%$ of cases. Values of aminotransferases are elevated, 5-40-fold. Biopsy has shown focal necrosis with mild inflammatory response in the portal areas and sinusoids and ultrastructural 
changes (249-253). The abnormality disappears promptly on stopping the drug. Overdoses of aspirin lead to microvesicular steatosis $(249,254)$.

In a study reported by the Acute Liver Failure Study Group, prolonged administration of high doses of NSAIDs for RA resulted in irreversible acute liver failure that led to liver transplant or death (255).

Other cytotoxic drugs have been employed in the treatment of RA, although not as widely used (251). The effects of DMARDs on the liver, especially those of MTX, are important to consider as possible triggers for hepatotoxicity. Glycogen inclusions in the nuclei are described as prominent in DILI. These features are common findings in the liver of diabetics but can be also seen in nondiabetic individuals. Particular attention has been paid to the association with prolonged MTXexposure. Thus, the steatosis produced by MTX leads primarily to hepatomegaly as a clinical manifestation (256).

The diagnosis of drug-induced injury can often be difficult. The relationship between drugingestion and toxicity is not always clear. Patients may be taking multiple medications making identification of the offending agent difficult, and they may have concomitant diseases, which can produce similar clinical and laboratory features. Characteristics suggesting drug toxicity include good health prior to ingesting the drug, clinical illness or biochemical abnormalities developing after beginning the drug, and after the drug is withdrawn. If an immunologic reaction is suspected, the illness will generally recur upon reintroduction of the offending substance. However, rechallenge is not advised.

Dose and frequency related adverse events have not been reported in the clinical trials with anti-TNF medication. Infections generally tend to occur during the first 1-2 years of treatment with anti-TNF (32). Therefore after a prolonged immune suppression the initial infection is reactivated. However, the majority of non-viral opportunistic infections occurred in the first 6 months of treatment with anti-TNF (33). Regarding cutaneous AEs primarily appear in first few months of treatment (64). Specific infusion-related severe anaphylactic reactions related to the presence of anti-IFX ADAs; scheduled dosing is thus preferred over episodic dosing in order to avoid ADAs (66). Autoimmune AEs are also associated with the presence of autoantibodies (101).

Neurological AEs occurred between a few months to a few years of anti-TNF treatment (same wide range of treatment duration for all of IFX, ADM and ETN) (133). Haematologic effects such as thrombocytopenia, neutropenia, thrombosis occurred between a few weeks to several months of anti-TNF treatment (157).

We conclude that the number and severity of the ADRs have no relationship with dose or length of anti-TTNF treatment. The only exception is immune-mediated AEs, which tend to occur more frequently in the presence of ADAs or autoantibodies. The presence of ADA occur more frequently when treatment is not administered continuously.

As a result of the frequent co-treatment with anti-TNF biologicals and DMARDs or NSAIDs, the effects of all therapeutics need to be considered, and thus the superimposed effects of drug-drug interactions cannot be discounted for both immunemediated mechanisms and those resulting from abnormal drug metabolism and clearance. Pharmacovigilance practice is vital for the successful development, marketing and defence of pharmaceutical products.

The scope of the search for safe anti-TNF therapeutics should be broadened to the molecular level and cover various receptors involved in the side effects and also to explore interaction with other therapeutics that might be given concomitantly. In addition, to predict various side effects of anti-TNFs, identification of readily measured biomarkers is of therapeutic interest. We recommend laboratory monitoring of TNF levels in blood and the ADA to different anti-TNF therapeutics. To avoid possible NSAID hypersensitivity we recommend the use of lymphocyte toxicity assay to the specific NSAID.

\section{CONCLUSION}

Adverse drug reactions remain a persistent concern in the prescription of many commonly-used therapeutic agents in clinical practice. Anti-TNF biologicals are efficient and generally safe in the treatment of patients with RA. Increased experience resulting from their extensive use has verified their overall safety profile with favorable risk-benefit ratio. However, caution is strongly advised in the administration of biological therapies. The use of 
anti-TNF therapies in combination with NSAIDs by individuals with chronic liver disease can provoke development of hepatotoxicity. Physicians should monitor patients for infections. Moreover, anti-TNF agents per se and in combination with other medication administered are potential causes of drug-induced, cardiovascular, gastrointestinal and liver injury. Monitoring remains the cornerstone of early diagnosis and effective management. From the point of view of pharmaceutical companies and health authorities, post-marketing surveillance continues to be paramount with every newly introduced agent. From the perspective of physicians and their patients, pharmacovigilance and personalized medicine provide the necessary tools for optimizing therapy while minimizing side effects.

\section{ACKNOWLEDGMENTS}

The present work was funded by In Vitro Drug Safety and Biotechnology, Toronto, ON, Canada.

\section{REFERENCES}

1. Neuman MG. Apoptosis in diseases of the liver. Crit Rev Clin Lab Sci. 2001;38:109-66.

2. Chung EY, Kim SJ, Ma XJ. Regulation of cytokine production during phagocytosis of apoptotic cells. Cell Res. 2006;16:154-61.

3. Frankenberg T, Kirschnek S, Häcker H, Häcker G. Phagocytosis-induced apoptosis of macrophages is linked to uptake, killing and degradation of bacteria. Eur J Immunol. 2008;38:204-15.

4. Cope AP, Londei M, Chu NR, Cohen SB, Elliott MJ, Brennan FM, Maini RN, Feldmann M. Chronic exposure to tumor necrosis factor (TNF) in vitro impairs the activation of $\mathrm{T}$ cells through the $\mathrm{T}$ cell receptor/CD3 complex; reversal in vivo by anti-TNF antibodies in patients with rheumatoid arthritis. J Clin Invest. 1994;94:749-60.

5. Maurice MM, van der Graaff WL, Leow A, Breedveld FC, van Lier RA, Verweij CL. Treatment with monoclonal anti-tumor necrosis factor alpha antibody results in an accumulation of Th1 CD4+ T cells in the peripheral blood of patients with rheumatoid arthritis. Arthritis Rheum. 1999;42:2166-73.

6. Berg L, Lampa J, Rogberg S, van Vollenhoven R, Klareskog L. Increased peripheral $\mathrm{T}$ cell reactivity to microbial antigens and collagen type II in rheumatoid arthritis after treatment with soluble TNFalpha receptors. Ann Rheum Dis. 2001;60:1339.
7. Schlüter D, Deckert M. The divergent role of tumor necrosis factor receptors in infectious diseases. Microbes Infect. 2000;2:1285-92.

8. Ellerin T, Rubin RH, Weinblatt ME. Infections and anti-tumor necrosis factor alpha therapy. Arthritis Rheum. 2003;48:3013-22.

9. Cohen LE, Nanau RM, Delzor F, Neuman MG. Biological Therapies in Inflammatory Bowel Disease. Transl Res. 2014. In press. doi: 10.1016/j.trs1.2014.01.002.

10. Maini R, St Clair EW, Breedveld F, Furst D, Kalden J, Weisman M, Smolen J, Emery P, Harriman G, Feldmann M, Lipsky P. Infliximab (chimeric antitumour necrosis factor alpha monoclonal antibody) versus placebo in rheumatoid arthritis patients receiving concomitant methotrexate: a randomised phase III trial. ATTRACT Study Group. Lancet. 1999;354:1932-9.

11. Lipsky PE, van der Heijde DM, St Clair EW, Furst DE, Breedveld FC, Kalden JR, Smolen JS, Weisman M, Emery P, Feldmann M, Harriman GR, Maini RN. Infliximab and methotrexate in the treatment of rheumatoid arthritis. Anti-Tumor Necrosis Factor Trial in Rheumatoid Arthritis with Concomitant Therapy Study Group. N Engl J Med. 2000;343:1594-602.

12. St. Clair EW, van der Heijde DM, Smolen JS, Maini RN, Bathon JM, Emery P, Keystone E, Schiff M, Kalden JR, Wang B, Dewoody K, Weiss R, Baker D. Combination of infliximab and methotrexate therapy for early rheumatoid arthritis: a randomized, controlled trial. Arthritis Rheum. 2004;50:3432-43.

13. Westhovens R, Yocum D, Han J, Berman A, Strusberg I, Geusens P, Rahman MU. The safety of infliximab, combined with background treatments, among patients with rheumatoid arthritis and various comorbidities: a large, randomized, placebocontrolled trial. Arthritis Rheum. 2006;54:1075-86.

14. Ruperto N, Lovell DJ, Cuttica R, Wilkinson N, Woo P, Espada G, Wouters C, Silverman ED, Balogh Z, Henrickson M,Apaz MT, Baildam E, Fasth A, Gerloni V, Lahdenne P, Prieur AM, Ravelli A, Saurenmann RK, Gamir ML, Wulffraat N,Marodi L, Petty RE, Joos R, Zulian F, McCurdy D, Myones BL, Nagy K, Reuman P, Szer I, Travers S, Beutler A, Keenan G, Clark J, Visvanathan S, Fasanmade A, Raychaudhuri A, Mendelsohn A, Martini A, Giannini EH. A randomized, placebo-controlled trial of infliximab plus methotrexate for the treatment of polyarticular-course juvenile rheumatoid arthritis. Arthritis Rheum. 2007;56:3096-106.

15. van der Heijde D, Dijkmans B, Geusens P, Sieper J, DeWoody K, Williamson P, Braun J. Efficacy and safety of infliximab in patients with ankylosing spondylitis: results of a randomized, placebocontrolled trial (ASSERT). Arthritis Rheum. 
2005;52:582-91

16. Bathon JM, Martin RW, Fleischmann RM, Tesser JR, Schiff MH, Keystone EC, Genovese MC, Wasko MC, Moreland LW, Weaver AL, Markenson J, Finck BK. A comparison of etanercept and methotrexate in patients with early rheumatoid arthritis. N Engl J Med. 2000;343:1586-93.

17. Klareskog L, van der Heijde D, de Jager JP, Gough A, Kalden J, Malaise M, Martín Mola E, Pavelka K, Sany J, Settas L, Wajdula J, Pedersen R, Fatenejad $\mathrm{S}$, Sanda M. Therapeutic effect of the combination of etanercept and methotrexate compared with each treatment alone in patients with rheumatoid arthritis: double-blind randomised controlled trial. Lancet. 2004;363:675-81.

18. van Riel PL, Taggart AJ, Sany J, Gaubitz M, Nab HW, Pedersen R, Freundlich B, MacPeek. D. Efficacy and safety of combination etanercept and methotrexate versus etanercept alone in patients with rheumatoid arthritis with an inadequate response to methotrexate: the ADORE study. Ann Rheum Dis. 2006;65:1478-83.

19. Emery P, Breedveld FC, Hall S, Durez P, Chang DJ, Robertson D, Singh A, Pedersen RD, Koenig AS, Freundlich B. Comparison of methotrexate monotherapy with a combination of methotrexate and etanercept in active, early, moderate to severe rheumatoid arthritis (COMET): a randomised, double-blind, parallel treatment trial. Lancet. 2008;372:375-82.

20. Weinblatt ME, Keystone EC, Furst DE, Moreland LW, Weisman MH, Birbara CA, Teoh LA, Fischkoff SA, Chartash EK. Adalimumab, a fully human anti-tumor necrosis factor alpha monoclonal antibody, for the treatment of rheumatoid arthritis in patients taking concomitant methotrexate: the ARMADA trial. Arthritis Rheum. 2003;48:35-45.

21. Keystone E, Heijde Dv, Mason D Jr, Landewé R, Vollenhoven RV, Combe B, Emery P, Strand V, Mease P, Desai C,Pavelka K. Certolizumab pegol plus methotrexate is significantly more effective than placebo plus methotrexate in active rheumatoid arthritis: findings of a fifty-two-week, phase III, multicenter, randomized, double-blind, placebocontrolled, parallel-group study. Arthritis Rheum. 2008;58:3319-29.

22. Keystone EC, Genovese MC, Klareskog L, Hsia EC, Hall ST, Miranda PC, Pazdur J, Bae SC, Palmer W, Zrubek J, Wiekowski M, Visvanathan $\mathrm{S}, \mathrm{Wu} \mathrm{Z}$, Rahman MU. Golimumab, a human antibody to tumour necrosis factor \{alpha\} given by monthly subcutaneous injections, in active rheumatoid arthritis despite methotrexate therapy: the GOFORWARD Study. Ann Rheum Dis. 2009;68:78996.

23. Fleischmann R, Vencovsky J, van Vollenhoven RF,
Borenstein D, Box J, Coteur G, Goel N, Brezinschek HP, Innes A,Strand V. Efficacy and safety of certolizumab pegol monotherapy every 4 weeks in patients with rheumatoid arthritis failing previous disease-modifying antirheumatic therapy: the FAST4WARD study. Ann Rheum Dis. 2009;68:805-11.

24. Emery P, Fleischmann RM, Moreland LW, Hsia EC, Strusberg I, Durez P, Nash P, Amante EJ, Churchill M, Park W, Pons-Estel BA, Doyle MK, Visvanathan $\mathrm{S}, \mathrm{Xu} \mathrm{W}$, Rahman MU. Golimumab, a human antitumor necrosis factor alpha monoclonal antibody, injected subcutaneously every four weeks in methotrexate-naive patients with active rheumatoid arthritis: twenty-four-week results of a phase III, multicenter, randomized, double-blind, placebocontrolled study of golimumab before methotrexate as first-line therapy for early-onset rheumatoid arthritis. Arthritis Rheum. 2009;60:2272-83.

25. Keystone EC, Genovese MC, Klareskog L, Hsia EC, Hall ST, Miranda PC, Pazdur J, Bae SC, Palmer W, Zrubek J, Wiekowski M, Visvanathan $\mathrm{S}, \mathrm{Wu} \mathrm{Z}$, Rahman MU. Golimumab, a human antibody to tumour necrosis factor \{alpha\} given by monthly subcutaneous injections, in active rheumatoid arthritis despite methotrexate therapy: the GOFORWARD Study. Ann Rheum Dis. 2009;68:78996.

26. Smolen JS, Kay J, Doyle MK, Landewé R, Matteson EL, Wollenhaupt J, Gaylis N, Murphy FT, Neal JS, Zhou Y, Visvanathan S, Hsia EC, Rahman MU. Golimumab in patients with active rheumatoid arthritis after treatment with tumour necrosis factor alpha inhibitors (GO-AFTER study): a multicentre, randomised, double-blind, placebo-controlled, phase III trial. Lancet. 2009;374:210-21.

27. Janssen Biotech, Inc. REMICADE® (infliximab). Highlights of Prescribing Information. 2013. http://www.remicade.com/shared/product/remicade/ prescribing-information.pdf.

28. AbbVie, Inc. HUMIRA® (adalimumab). Highlights of Prescribing Information. 2013. http://www.rxabbvie.com/pdf/humira.pdf.

29. UCB, Inc. CIMZIA® (certolizumab pegol). Highlights of Prescribing Information. 2012. http://www.cimzia.com/pdf/Prescribing_Information .pdf.

30. Janssen Biotech, Inc. SIMPONI ${ }^{\circledR}$ (golimumab). Highlights of Prescribing Information. 2013. http://www.simponi.com/sites/default/files/pdf/presc ribing-information.pdf.

31. Amgen, Inc. ENBREL ${ }^{\circledR}$ (etanercept). Highlights of Prescribing Information. 2013. http://www.enbrel.com/prescribinginformation.jspx.

32. Salmon-Ceron D, Tubach F, Lortholary O, 
Chosidow O, Bretagne S, Nicolas N, Cuillerier E, Fautrel B, Michelet C, Morel J, Puéchal X, Wendling D, Lemann M, Ravaud P, Mariette X. Drug-specific risk of non-tuberculosis opportunistic infections in patients receiving anti-TNF therapy reported to the 3-year prospective French RATIO registry. Ann Rheum Dis. 2011;70:616-23

33. Mendes D, Alves C, Batel-Marques F. Safety profiles of adalimumab, etanercept and infliximab: a pharmacovigilance study using a measure of disproportionality in a database of spontaneously reported adverse events. J Clin Pharm Ther. 2014;39:307-13.

34. Baddley JW, Winthrop KL, Chen L, Liu L, Grijalva CG, Delzell E, Beukelman T, Patkar NM, Xie F, Saag KG, Herrinton LJ, Solomon DH, Lewis JD, Curtis JR. Non-viral opportunistic infections in new users of tumour necrosis factor inhibitor therapy: results of the SAfety Assessment of Biologic ThERapy (SABER) Study. Ann Rheum Dis. 2013. In press. doi: 10.1136/annrheumdis-2013-203407.

35. Nordgaard-Lassen I, Dahlerup JF, Belard E, Gerstoft J, Kjeldsen J, Kragballe K, Ravn P, Sørensen IJ, Theede K, Tjellesen L. Guidelines for screening, prophylaxis and critical information prior to initiating anti-TNF-alpha treatment. Dan Med J. 2012;59:C4480.

36. Mariette X, Gottenberg JE, Ravaud P, Combe B. Registries in rheumatoid arthritis and autoimmune diseases: data from the French registries. Rheumatology (Oxford). 2011;50:222-9.

37. Lee SK, Kim SY, Kim EY, Jung JY, Park MS, Kim YS, Kim SK, Chang J, Kang YA. Mycobacterial infections in patients treated with tumor necrosis factor antagonists in South Korea. Lung. 2013;191:565-71.

38. Winthrop KL, Baxter R, Liu L, Varley CD, Curtis JR, Baddley JW, McFarland B, Austin D, Radcliffe L, Suhler E, Choi D, Rosenbaum JT, Herrinton LJ. Mycobacterial diseases and antitumour necrosis factor therapy in USA. Ann Rheum Dis. 2013;72:37-42.

39. Dixon WG, Hyrich KL, Watson KD, Lunt M, Galloway J, Ustianowski A. Drug-specific risk of tuberculosis in patients with rheumatoid arthritis treated with anti-TNF therapy: results from the British Society for Rheumatology Biologics Register (BSRBR). Ann Rheum Dis. 2010;69:522-8.

40. Navarra SV, Tang B, Lu L, Lin HY, Mok CC, Asavatanabodee P, Suwannalai P, Hussein H, Rahman MU. Risk of tuberculosis with anti-tumor necrosis factor- $\alpha$ therapy: substantially higher number of patients at risk in Asia. Int J Rheum Dis. 2013 In press. doi: 10.1111/1756-185X.12188.

41. Horsburgh CR Jr. Priorities for the treatment of latent tuberculosis infection in the United States. N
Engl J Med. 2004;350:2060-2067.

42. Reenaers C, Belaiche J, Louis E. Should patients under long-term anti-TNF therapies be followed for tuberculosis contamination? Inflamm Bowel Dis. 2010;16:1271-2.

43. Hatemi G, Melikoglu M, Ozbakir F, Tascilar K, Yazici H. Quantiferon-TB Gold in tube assay for the screening of tuberculosis before and during treatment with tumor necrosis factor alpha antagonists. Arthritis Res Ther. 2012;14:R147.

44. Ke WM, Chen LS, Parng IM, Chen WW, On AW. Risk of tuberculosis in rheumatoid arthritis patients on tumour necrosis factor-alpha inhibitor treatment in Taiwan. Int J Tuberc Lung Dis. 2013;17:1590-5.

45. Malaviya AN, Kapoor S, Garg S, Rawat R, Shankar S, Nagpal S, Khanna D, Furst DE. Preventing tuberculosis flare in patients with inflammatory rheumatic diseases receiving tumor necrosis factoralpha inhibitors in India -- An audit report. J Rheumatol. 2009;36:1414-20.

46. Mankia S, Peters JE, Kang S, Moore S, Ehrenstein MR. Tuberculosis and anti-TNF treatment: experience of a central London hospital. Clin Rheumatol. 2011;30:399-401.

47. Arend SM, Leyten EM, Franken WP, Huisman EM, van Dissel JT. A patient with de novo tuberculosis during anti-tumor necrosis factor-alpha therapy illustrating diagnostic pitfalls and paradoxical response to treatment. Clin Infect Dis. 2007;45:1470-5.

48. Hernández MV, Meineri M, Sanmartí R. Skin lesions and treatment with tumor necrosis factor alpha antagonists. Reumatol Clin. 2013;9:53-61.

49. Peña-Sagredo JL, Hernández MV, Fernandez-Llanio N, Giménez-Ubeda E, Muñoz-Fernandez S, Ortiz A, Gonzalez-Gay MA, Fariñas MC. Listeria monocytogenes infection in patients with rheumatic diseases on TNF-alpha antagonist therapy: the Spanish Study Group experience. Clin Exp Rheumatol. 2008;26:854-9.

50. Lanternier F, Tubach F, Ravaud P, Salmon D, Dellamonica P, Bretagne S, Couret M, Bouvard B, Debandt M, Gueit I,Gendre JP, Leone J, Nicolas N, Che D, Mariette X, Lortholary O. Incidence and Risk Factors of Legionella pneumophila Pneumonia During Anti-Tumor Necrosis Factor Therapy: A Prospective French Study. Chest. 2013;144:990-8.

51. Tsiodras S, Samonis G, Boumpas DT, Kontoyiannis DP. Fungal infections complicating tumor necrosis factor alpha blockade therapy. Mayo Clin Proc. 2008;83:181-94.

52. Wissmann G, Morilla R, Martín-Garrido I, Friaza V, Respaldiza N, Povedano J, Praena-Fernández JM, Montes-Cano MA, Medrano FJ, Goldani LZ, de la Horra C, Varela JM, Calderón EJ. Pneumocystis jirovecii colonization in patients treated with 
infliximab. Eur J Clin Invest. 2011;41:343-8.

53. Kaur N, Mahl TC. Pneumocystis jiroveci (carinii) pneumonia after infliximab therapy: a review of 84 cases. Dig Dis Sci. 2007;52:1481-4.

54. Bergstrom L, Yocum DE, Ampel NM, Villanueva I, Lisse J, Gluck O, Tesser J, Posever J, Miller M, Araujo J, Kageyama DM, Berry M, Karl L, Yung $\mathrm{CM}$. Increased risk of coccidioidomycosis in patients treated with tumor necrosis factor alpha antagonists. Arthritis Rheum. 2004;50:1959-66.

55. Toussi SS, Pan N, Walters HM, Walsh TJ. Infections in children and adolescents with juvenile idiopathic arthritis and inflammatory bowel disease treated with tumor necrosis factor- $\alpha$ inhibitors: systematic review of the literature. Clin Infect Dis. 2013;57:1318-30.

56. Pérez-Alvarez R, Díaz-Lagares C, GarcíaHernández F, Lopez-Roses L, Brito-Zerón P, Pérezde-Lis M, Retamozo S, Bové A, Bosch X, SanchezTapias JM, Forns X, Ramos-Casals M. Hepatitis B virus (HBV) reactivation in patients receiving tumor necrosis factor (TNF)-targeted therapy: analysis of 257 cases. Medicine (Baltimore). 2011;90:359-71.

57. Urata Y, Uesato R, Tanaka D, Kowatari K, Nitobe $T$, Nakamura Y, Motomura S. Prevalence of reactivation of hepatitis $\mathrm{B}$ virus replication in rheumatoid arthritis patients. Mod Rheumatol. 2011;21:16-23.

58. Oshima $\mathrm{Y}$, Tsukamoto $\mathrm{H}$, Tojo A. Association of hepatitis B with antirheumatic drugs: a case-control study. Mod Rheumatol. 2013;23:694-704.

59. Zhang X, Zhang F, Wu D, Bao C, Zhu P, Zhang X, Huang C, He D, Tao Y, Fang Y, Gu J, Wu H, Sun L, Yang X, Huang F, Xu H, Zhao D, Zhang M, Zheng Y, Li Z. Safety of infliximab therapy in rheumatoid arthritis patients with previous exposure to hepatitis B virus. Int J Rheum Dis. 2013;16:408-12.

60. Caporali R, Bobbio-Pallavicini F, Atzeni F, Sakellariou G, Caprioli M, Montecucco C, SarziPuttini P. Safety of tumor necrosis factor alpha blockers in hepatitis B virus occult carriers (hepatitis B surface antigen negative/anti-hepatitis B core antigen positive) with rheumatic diseases. Arthritis Care Res (Hoboken). 2010;62:749-54.

61. Vassilopoulos D, Apostolopoulou A, Hadziyannis E, Papatheodoridis GV, Manolakopoulos S, Koskinas J, Manesis EK, Archimandritis AI. Long-term safety of anti-TNF treatment in patients with rheumatic diseases and chronic or resolved hepatitis B virus infection. Ann Rheum Dis. 2010;69:1352-5.

62. Serac G, Tubach F, Mariette X, Salmon-Céron D, Ravaud P, Lioté F, Laharie D, Ziza JM, Marguerie L, Bonnet C,Falgarone G, Nicolas N, Lortholary O, Chosidow O. Risk of herpes zoster in patients receiving anti-TNF- $\alpha$ in the prospective French RATIO registry. J Invest Dermatol. 2012;132:726-9.
63. Balandraud N, Guis S, Meynard JB, Auger I, Roudier J, Roudier C. Long-term treatment with methotrexate or tumor necrosis factor alpha inhibitors does not increase Epstein-Barr virus load in patients with rheumatoid arthritis. Arthritis Rheum. 2007;57:762-7.

64. Hernández MV, Sanmartí R, Cañete JD, Descalzo MA, Alsina M, Carmona L, Gomez-Reino JJ. Cutaneous adverse events during treatment of chronic inflammatory rheumatic conditions with tumor necrosis factor antagonists: study using the Spanish registry of adverse events of biological therapies in rheumatic diseases. Arthritis Care Res (Hoboken). 2013;65:2024-31.

65. Maggi E, Vultaggio A, Matucci A. Acute infusion reactions induced by monoclonal antibody therapy. Expert Rev Clin Immunol. 2011;7:55-63.

66. Vultaggio A, Matucci A, Nencini F, Pratesi S, Parronchi P, Rossi O, Romagnani S, Maggi E. Antiinfliximab $\operatorname{IgE}$ and non- $\operatorname{IgE}$ antibodies and induction of infusion-related severe anaphylactic reactions. Allergy. 2010;65:657-61.

67. Lecluse LL, Piskin G, Mekkes JR, Bos JD, de Rie MA. Review and expert opinion on prevention and treatment of infliximab-related infusion reactions. $\mathrm{Br}$ J Dermatol. 2008;159:527-36.

68. Brennan PJ, Rodriguez Bouza T, Hsu FI, Sloane DE, Castells MC. Hypersensitivity reactions to mAbs: 105 desensitizations in 23 patients, from evaluation to treatment. J Allergy Clin Immunol. 2009;124:1259-66.

69. Puxeddu I, Giori L, Rocchi V, Bazzichi L, Bombardieri S, Tavoni A, Migliorini P, Del Corso I. Hypersensitivity reactions during treatment with infliximab, etanercept, and adalimumab. Ann Allergy Asthma Immunol. 2012;108:123-4.

70. Matucci A, Pratesi S, Petroni G, Nencini F, Virgili G, Milla M, Maggi E, Vultaggio A. Allergological in vitro and in vivo evaluation of patients with hypersensitivity reactions to infliximab. Clin Exp Allergy. 2013;43:659-64.

71. Kelsall J, Rogers P, Galindo G, De Vera MA. Safety of infliximab treatment in patients with rheumatoid arthritis in a real-world clinical setting: description and evaluation of infusion reactions. J Rheumatol. 2012;39:1539-45.

72. Wright RC. Atopic dermatitis-like eruption precipitated by infliximab. J Am Acad Dermatol. 2003;49:160-1.

73. Chan JL, Davis-Reed L, Kimball AB. Counterregulatory balance: atopic dermatitis in patients undergoing infliximab infusion therapy. J Drugs Dermatol. 2004;3:315-8.

74. Desai D, Goldbach-Mansky R, Milner JD, Rabin RL, Hull K, Pucino F, Colburn N. Anaphylactic reaction to anakinra in a rheumatoid arthritis patient 
intolerant to multiple nonbiologic and biologic disease-modifying antirheumatic drugs. Ann Pharmacother. 2009;43:967-72.

75. Sendur OF, Turan Y, Berkit IK, Tastaban E. Angiooedema in a patient treated with etanercept for rheumatoid arthritis. Basic Clin Pharmacol Toxicol. 2009;104:488-90.

76. Bavbek S, Aydın O, Ataman S, Cahill K, Castells $\mathrm{M}$. Injection-site reaction to etanercept: role of skin test in the diagnosis of such reaction and successful desensitization. Allergy. 2011;66:1256-7.

77. Leloup P, Daviet V, Chiffoleau A, Dréno B. Urticaria pigmentosa after treatment with TNF antagonists: a case report. Arch Dermatol. 2011;147:1459-60.

78. Quismorio A, Brahmbhatt B, Houng M, Panush RS. Etanercept allergy and anaphylaxis. J Rheumatol. 2012;39:2225-6.

79. Tugnet N, Youssef A, Whallett AJ. Wells' syndrome (eosinophilic cellulitis) secondary to infliximab. Rheumatology (Oxford). 2012;51:195-6.

80. Crayne CB, Gerhold K, Cron RQ. Anaphylaxis to etanercept in two children with juvenile idiopathic arthritis. J Clin Rheumatol. 2013;19:129-31.

81. Miki H, Okamoto A, Ishigaki K, Sasaki O, Sumitomo S, Fujio K, Yamamoto K. Cardiopulmonary arrest after severe anaphylactic reaction to second infusion ofinfliximab in a patient with ankylosing spondylitis. J Rheumatol. 2011;38:1220.

82. Rosenstein RK, Panush RS, Kramer N, Rosenstein ED. Hypereosinophilia and Seroconversion of Rheumatoid Arthritis. Clin Rheumatol. 2014. In press. DOI 10.1007/s10067-014-2566-6.

83. Quercia O, Emiliani F, Foschi FG, Stefanini GF. Adalimumab desensitization after anaphylactic reaction. Ann Allergy Asthma Immunol. 2011;106:547-8.

84. van Dijken TD, Vastert SJ, Gerloni VM, Pontikaki I, Linnemann K, Girschick H, Armbrust W, Minden K, Prince FH,Kokke FT, Nieuwenhuis EE, Horneff G, Wulffraat NM. Development of inflammatory bowel disease in patients with juvenile idiopathic arthritis treated with etanercept. J Rheumatol. 2011;38:1441-6.

85. Minden K, Niewerth M, Zink A, Seipelt E, Foeldvari I, Girschick H, Ganser G, Horneff G. Long-term outcome of patients with JIA treated with etanercept, results of the biologic register JuMBO. Rheumatology (Oxford). 2012;51:1407-15.

86. Barrientos N, García-Sánchez S, Domínguez JD. Letter: Lichenoid eruption induced by etanercept. Dermatol Online J. 2012;18:15.

87. Pontikaki I, Shahi E, Frasin LA, Gianotti R, Gelmetti C, Gerloni V, Meroni PL. Skin manifestations induced by TNF-alpha inhibitors in juvenile idiopathic arthritis. Clin Rev Allergy Immunol. 2012;42:131-4.

88. Chiriac A, Foia L, Chiriac AE, Ancuţa C, Manea P, Profire L, Filip F. Lichen planus secondary complications associated with the use of biologic therapy for rheumatoid arthritis. Rom J Morphol Embryol. 2013;54:829-31.

89. Fujikawa K, Kawakami A, Hayashi T, Iwamoto N, Kawashiri SY, Aramaki T, Ichinose K, Tamai M, Arima K, Kamachi M, Yamasaki S, Nakamura H, Ida H, Origuchi T, Eguchi K. Cutaneous vasculitis induced by TNF inhibitors: a report of three cases. Mod Rheumatol. 2010;20:86-9.

90. Pàmies A, Castro S, Poveda MJ, Fontova R. Leucocytoclastic vasculitis associated with golimumab. Rheumatology (Oxford). 2013;52:19213.

91. Sokumbi O, Wetter DA, Makol A, Warrington KJ. Vasculitis associated with tumor necrosis factor- $\alpha$ inhibitors. Mayo Clin Proc. 2012;87:739-45.

92. Parekh K, Ching D, Rahman MU, Stamp LK. Onset of Wegener's granulomatosis during therapy with golimumab for rheumatoid arthritis: a rare adverse event? Rheumatology (Oxford). 2010;49:1785-7.

93. Rolle AS, Zimmermann B, Poon SH. Etanerceptinduced Henoch-Schönlein purpura in a patient with ankylosing spondylitis. J Clin Rheumatol. 2013;19:90-3.

94. Cancelliere N, Barranco P, Vidaurrázaga C, Benito DM, Quirce S. Subacute prurigo and eosinophilia in a patient with rheumatoid arthritis receiving infliximab and etanercept. J Investig Allergol Clin Immunol. 2011;21:248-9.

95. Mounach A, Rezqi A, Nouijai A, Ghozlani I, Achemlal L, Maghraoui AE, Bezza A. StevensJohnson syndrome complicating adalimumab therapy in rheumatoid arthritis disease. Rheumatol Int. 2013;33:1351-3.

96. Sawada Y, Nakamura M, Hama K, Hino R, Tokura Y. A high serum concentration of chemerin in pustular dermatitis paradoxically induced by etanercept. J Am Acad Dermatol. 2012;66:e182-4.

97. Klein R, Rosenbach M, Kim EJ, Kim B, Werth VP, Dunham J. Tumor necrosis factor inhibitorassociated dermatomyositis. Arch Dermatol. 2010;146:780-4.

98. Liu SW, Velez NF, Lam C, Femia A, Granter SR, Townsend HB, Vleugels RA. Dermatomyositis induced by anti-tumor necrosis factor in a patient with juvenile idiopathic arthritis. JAMA Dermatol. 2013;149:1204-8.

99. Ramírez J, Hernández MV, Galve J, Cañete JD, Sanmartí R. Morphea associated with the use of adalimumab: a case report and review of the literature. Mod Rheumatol. 2012;22:602-4.

100.Puertas-Abreu E, Polanco ER, Azocar M, 
Mundarain LA, Nuñez-Sotelo CM, Montaño R, Vivas FH, Noguera ZT, Marín F, Bellorin O, Rivas $\mathrm{JG}$, Toro E, Benzaquen E, Rauseo M, Gutiérrez González LA. Onset of lupus like syndrome in patients with spondyloarthritis treated with antiTNF- $\alpha$. Int Arch Med. 2012;5:7.

101. Vaz JL, Andrade CA, Pereira AC, Martins Mde F, Levy RA. Systematic review of infliximab-induced autoantibodies and systemic lupus erythematosus. Rev Bras Reumatol. 2013;53:358-64.

102. Wetter DA, Davis MD. Lupus-like syndrome attributable to anti-tumor necrosis factor alpha therapy in 14 patients during an 8-year period at Mayo Clinic. Mayo Clin Proc. 2009;84:979-84.

103. Vezzoli P, Violetti SA, Serini SM, Muratori S, Berti E, Crosti C. Cutaneous lupus erythematosus induced by adalimumab. J Dermatol. 2011;38:283-4.

104. Williams VL, Cohen PR. TNF alpha antagonistinduced lupus-like syndrome: report and review of the literature with implications for treatment with alternative TNF alpha antagonists. Int J Dermatol. 2011;50:619-25.

105.Diaz JC, Vallejo S, Cañas CA. Drug-induced lupus in anti-TNF-alpha therapy and its treatment with rituximab. Rheumatol Int. 2012;32:3315-7.

106. Guerin M, Haettich B, Bara C, Artru L, Prophette B, Célérier $\mathrm{P}$, Maillard $\mathrm{H}$. Lupus attributable to antiTNF therapy and revealed by interstitial granulomatous dermatitis. Rheumatol Int. 2012;32:2937-40.

107.Hawryluk EB, Linskey KR, Duncan LM, Nazarian RM. Broad range of adverse cutaneous eruptions in patients on TNF-alpha antagonists. J Cutan Pathol. 2012;39:481-92.

108. Sifuentes Giraldo WA, Ahijón Lana M, García Villanueva MJ, González García C, Vázquez Diaz M. Chilblain lupus induced by TNF- $\alpha$ antagonists: a case report and literature review. Clin Rheumatol. 2012;31:563-8.

109.Santiago T, Santiago MG, Rovisco J, Duarte C, Malcata A, da Silva JA. A case of infliximabinduced lupus in a patient with ankylosing spondylitis: is it safe switch to another anti-TNF- $\alpha$ agent? Clin Rheumatol. 2013;32:1819-22.

110.Akgül O, Kılıç G, Kılıç E, Cüce I, Ozgöçmen S. A patient with ankylosing spondylitis who developed infliximab-induced lupus and treated with etanercept. Rheumatol Int. 2014;34:443-4.

111.Brunasso AM, Aberer W, Massone C. Subacute lupus erythematosus during treatment with golimumab for seronegative rheumatoid arthritis. Lupus. 2014;23:201-3.

112.Cemil BC, Atas H, Canpolat F, Akca Y, Sasmaz R. Infliximab-induced discoid lupus erythematosus. Lupus. 2013;22:515-8.

113.Almoallim H, Al-Ghamdi Y, Almaghrabi H, Alyasi
O. Anti-Tumor Necrosis Factor- $\alpha$ Induced Systemic Lupus Erythematosus. Open Rheumatol J. 2012;6:315-9.

114.Joyau C, Veyrac G, Dixneuf V, Jolliet P. Antitumour necrosis factor alpha therapy and increased risk of de novo psoriasis: is it really a paradoxical side effect? Clin Exp Rheumatol. 2012;30:700-6.

115. Nguyen K, Vleugels RA, Velez NF, Merola JF, Qureshi AA. Psoriasiform reactions to anti-tumor necrosis factor $\alpha$ therapy. J Clin Rheumatol. 2013;19:377-81.

116. Teraki Y, Tanaka S, Hitomi K, Izaki S. A case of generalized psoriasiform and pustular eruption induced by infliximab: evidence for skin-homing Th17 in the pathogenesis. $\mathrm{Br} \mathrm{J}$ Dermatol. 2010;163:1347-51.

117.Glenn CJ, Kobraei KB, Russo JJ. New-onset psoriasis associated with adalimumab: a report of two cases. Dermatol Online J. 2011;17:15.

118. Perman MJ, Lovell DJ, Denson LA, Farrell MK, Lucky AW. Five cases of anti-tumor necrosis factor alpha-induced psoriasis presenting with severe scalp involvement in children. Pediatr Dermatol. 2012;29:454-9.

119. Madigan LM, Kaffenberger BH, Wong HK. Bullae and psoriasiform hyperkeratosis after treatment with golimumab. J Am Acad Dermatol. 2013;68:e195-6.

120. Shelling ML, Vitiello M, Lanuti EL, Miteva M, Romanelli P, Kerdel FA. A Case of Palmoplantar Pustulosis Induced by Certolizumab Pegol: New Anti-TNF-alpha Demonstrates the Same Class Effect. J Clin Aesthet Dermatol. 2012;5:40-1.

121. Sauder MB, Glassman SJ. Palmoplantar subcorneal pustular dermatosis following adalimumab therapy for rheumatoid arthritis. Int $\mathrm{J}$ Dermatol. 2013;52:624-8.

122.Boussemart L, Jacobelli S, Batteux F, Goulvestre C, Grange P, Carlotti A, Morini JP, Gorin I, Ziza JM, Avril MF, Dupin N. Autoimmune bullous skin diseases occurring under anti-tumor necrosis factor therapy: two case reports. Dermatology. 2010;221:201-5.

123.Ratnarathorn M, Raychaudhuri SP, Naguwa S. Disseminated granuloma annulare: a cutaneous adverse effect of anti-tnf agents. Indian J Dermatol. 2011;56:752-4.

124. Ozorio G, McGarity B, Bak H, Jordan AS, Lau H, Marshall C. Autoimmune hepatitis following infliximab therapy for ankylosing spondylitis. Med J Aust. 2007;187:524-6.

125.Tobon GJ, Cañas C, Jaller JJ, Restrepo JC, Anaya JM. Serious liver disease induced by infliximab. Clin Rheumatol. 2007;26:578-81.

126.Becker H, Willeke P, Domschke W, Gaubitz M. Etanercept tolerance in a patient with previous infliximab-induced hepatitis. Clin Rheumatol. 
2008;27:1597-8.

127.Harada K, Akai Y, Koyama S, Ikenaka Y, Saito Y. A case of autoimmune hepatitis exacerbated by the administration of etanercept in the patient with rheumatoid arthritis. Clin Rheumatol. 2008;27:10636.

128. Grasland A, Sterpu R, Boussoukaya S, Mahe I. Autoimmune hepatitis induced by adalimumab with successful switch to abatacept. Eur J Clin Pharmacol. 2012;68:895-8.

129.Nozaki K, Silver RM, Stickler DE, Abou-Fayssal NG, Giglio P, Kamen DL, Daniel R, Judson MA. Neurological deficits during treatment with tumor necrosis factor-alpha antagonists. Am J Med Sci. 2011;342:352-5.

130.Hemmati I, Kur J. Adalimumab-associated antiphospholipid syndrome: a case report and review of the literature. Clin Rheumatol. 2013;32:1095-8.

131. Aithal GP. Hepatotoxicity related to antirheumatic drugs. Nat Rev Rheumatol. 2011;7:139-50.

132.Deepak P, Stobaugh DJ, Sherid M, Sifuentes H, Ehrenpreis ED. Neurological events with tumour necrosis factor alpha inhibitors reported to the Food and Drug Administration Adverse Event Reporting System. Aliment Pharmacol Ther. 2013;38:388-96.

133. Seror R, Richez C, Sordet C, Rist S, Gossec L, Direz G, Houvenagel E, Berthelot JM, Pagnoux C, Dernis E, Melac-Ducamp S, Bouvard B, Asquier C, Martin A, Puechal X, Mariette X. Pattern of demyelination occurring during anti-TNF- $\alpha$ therapy: a French national survey. Rheumatology (Oxford). 2013;52:868-74.

134. Kay J, Fleischmann R, Keystone E, Hsia EC, Hsu B, Mack M, Goldstein N, Braun J, Kavanaugh A. Golimumab 3-year safety update: an analysis of pooled data from the long-term extensions of randomised, double-blind, placebo-controlled trials conducted in patients with rheumatoid arthritis, psoriatic arthritis or ankylosing spondylitis. Ann Rheum Dis. 2013. In press. doi: 10.1136/annrheumdis-2013-204195.

135. Mercieca C, Vella N, Borg AA. Demyelination during anti-TNFa therapy for ankylosing spondylitis. Mod Rheumatol. 2012;22:303-7.

136.Papadia M, Herbort CP. Infliximab-induced demyelination causes visual disturbance mistaken for recurrence of HLA-B27-related uveitis. Ocul Immunol Inflamm. 2010;18:482-4.

137.Lozeron P, Denier C, Lacroix C, Adams D. Longterm course of demyelinating neuropathies occurring during tumor necrosis factor-alpha-blocker therapy. Arch Neurol. 2009;66:490-7.

138. Andreadou E, Kemanetzoglou E, Brokalaki Ch, Evangelopoulos ME, Kilidireas C, Rombos A, Stamboulis E. Demyelinating Disease following Anti-TNFa Treatment: A Causal or Coincidental
Association? Report of Four Cases and Review of the Literature. Case Rep Neurol Med. 2013;2013:671935.

139. Matsumoto T, Nakamura I, Miura A, Momoyama G, Ito $\mathrm{K}$. New-onset multiple sclerosis associated with adalimumab treatment in rheumatoid arthritis: a case report and literature review. Clin Rheumatol. 2013;32:271-5.

140.Alshekhlee A, Basiri K, Miles JD, Ahmad SA, Katirji B. Chronic inflammatory demyelinating polyneuropathy associated with tumor necrosis factor-alpha antagonists. Muscle Nerve. 2010;41:723-7.

141.Alentorn A, Albertí MA, Montero J, Casasnovas C. Monofocal motor neuropathy with conduction block associated with adalimumab in rheumatoid arthritis. Joint Bone Spine. 2011;78:536-7.

142. Solomon AJ, Spain RI, Kruer MC, Bourdette D. Inflammatory neurological disease in patients treated with tumor necrosis factor alpha inhibitors. Mult Scler. 2011;17:1472-87.

143.Alvarez-Lario B, Prieto-Tejedo R, Colazo-Burlato M, Macarrón-Vicente J. Severe Guillain-Barré syndrome in a patient receiving anti-TNF therapy. Consequence or coincidence. A case-based review. Clin Rheumatol. 2013;32:1407-12.

144.Defty H, Sames E, Doherty T, Hughes R. Case report of transverse myelitis in a patient receiving etanercept for rheumatoid arthritis. Case Rep Rheumatol. 2013;2013:728371.

145. Makol A, Grover M. Adalimumab induced mononeuritis multiplex in a patient with refractory rheumatoid arthritis: a case report. Cases J. 2008;1:287.

146. Faillace C, de Almeida JR, de Carvalho JF. Optic neuritis after infliximab therapy. Rheumatol Int. 2013;33:1101-3.

147.Cereda CW, Zecca C, Mazzucchelli L, Valci L, Staedler C, Bassetti CL, Gobbi C. Tumefactive demyelinating lesions during etanercept treatment requiring decompressive hemicraniectomy. Mult Scler. 2013;19:820-3.

148.Ekici B, Aydın K, Cantez S, Ergül Y, Tatlı B. Etanercept-induced encephalopathy in a 7-year-old child. Pediatr Neurol. 2011;45:271-3.

149. Garg N, Woltjer R, Hamilton B, Neuwelt EA, Rosenbaum JT. A 67-year-old woman receiving tumor necrosis factor $\alpha$ inhibitor therapy presenting with neurologic dysfunction. Arthritis Care Res (Hoboken). 2013;65:658-65.

150.Ryu YS, Park SH, Kim JM, Kim EJ, Lee J, Kwok SK, Ju JH, Kim HY. A case of leukoencephalopathy associated with adalimumab-treated rheumatoid arthritis and a review of literature. Rheumatol Int. 2012;32:3481-5.

151.Bellizzi A, Anzivino E, Rodio DM, Palamara AT, 
Nencioni L, Pietropaolo V. New insights on human polyomavirus $\mathrm{JC}$ and pathogenesis of progressive multifocal leukoencephalopathy. Clin Dev Immunol. 2013;2013:839719.

152.Palazzo E, Yahia SA. Progressive multifocal leukoencephalopathy in autoimmune diseases. Joint Bone Spine. 2012;79:351-5.

153. Molloy ES, Calabrese LH. Progressive multifocal leukoencephalopathy associated with immunosuppressive therapy in rheumatic diseases: evolving role of biologic therapies. Arthritis Rheum. 2012;64:3043-51.

154.Keene DL, Legare C, Taylor E, Gallivan J, Cawthorn GM, Vu D. Monoclonal antibodies and progressive multifocal leukoencephalopathy. Can J Neurol Sci. 2011;38:565-71.

155.Kumar D, Bouldin TW, Berger RG. A case of progressive multifocal leukoencephalopathy in a patient treated with infliximab. Arthritis Rheum. 2010;62:3191-5.

156.Graff-Radford J, Robinson MT, Warsame RM, Matteson EL, Eggers SD, Keegan BM. Progressive multifocal leukoencephalopathy in a patient treated with etanercept. Neurologist. 2012;18:85-7.

157. Bessissow T, Renard M, Hoffman I, Vermeire S, Rutgeerts P, Van Assche G. Review article: nonmalignant haematological complications of antitumour necrosis factor alpha therapy. Aliment Pharmacol Ther. 2012;36:312-23.

158.Haroon M, Daly M, Harney S. Re-challenge with etanercept in patients with etanercept-induced neutropenia. Clin Rheumatol. 2012;31:151-5.

159. Wenham C, Gadsby K, Deighton C. Three significant cases of neutropenia with etanercept. Rheumatology (Oxford). 2008;47:376-7.

160. Ottaviani S, Cerf-Payrastre I, Kemiche F, Pertuiset E. Adalimumab-induced neutropenia in a patient with rheumatoid arthritis. Joint Bone Spine. 2009;76:312-3.

161.Datta K, Ghosh RK, Ghosh SM. Serious neutropenia following etanercept administration in a 62 years female patient of rheumatoid arthritis. J Assoc Physicians India. 2010;58:643-4.

162.Levälampi T, Korpela M, Vuolteenaho K, Moilanen E. Etanercept and adalimumab treatment in patients with rheumatoid arthritis and spondyloarthropathies in clinical practice: adverse events and other reasons leading to discontinuation of the treatment. Rheumatol Int. 2008;28:261-9.

163. Azevedo VF, Silva MB, Marinello DK, Santos FD, Silva GB. Leukopenia and thrombocytopenia induced by etanercept: two case reports and literature review. Rev Bras Reumatol. 2012;52:1102.

164.Pathare SK, Heycock C, Hamilton J. TNFalpha blocker-induced thrombocytopenia. Rheumatology
(Oxford). 2006;45:1313-4.

165. Theodoridou A, Kartsios C, Yiannaki E, Markala D, Settas L. Reversible T-large granular lymphocyte expansion and neutropenia associated with adalimumab therapy. Rheumatol Int. 2006;27:201-2.

166. Bes C, Yazici A, Soy M. Monoclonal anti-TNF antibodies can elevate hemoglobin level in patients with ankylosing spondylitis. Rheumatol Int. 2013;33:1415-8.

167.Furst DE, Kay J, Wasko MC, Keystone E, Kavanaugh A, Deodhar A, Murphy FT, Magnus JH, Hsia EC, Hsu B, Xu S, Rahman MU, Doyle MK. The effect of golimumab on haemoglobin levels in patients with rheumatoid arthritis, psoriatic arthritis or ankylosing spondylitis. Rheumatology (Oxford). 2013;52:1845-55.

168. Szalay B, Acs L, Vásárhelyi B, Kovács L, Balog A. Successful use of tocilizumab in a patient with rheumatoid arthritis following severe pancytopenia during etanercept therapy. J Clin Rheumatol. 2011;17:377-9.

169. Martínez Santana V, Izquierdo Navarro M, Calleja Hernández MÁ, Sánchez Sánchez T, Sainz Gil M. Severe pancytopenia following etanercept administration in rheumatoid arthritis. Int $\mathrm{J}$ Rheum Dis. 2012;15:e78-9.

170.Araki D, Fujii H, Matsumura M, Yamagishi M, Yachie A, Kawano M. Etanercept-induced lupus accompanied by hemophagocytic syndrome. Intern Med. 2011;50:1843-8.

171.Kaneko A, Hirano Y, Fujibayashi T, Hattori Y, Terabe K, Kojima T, Ishiguro N. Twenty-four-week clinical results of adalimumab therapy in Japanese patients with rheumatoid arthritis: retrospective analysis for the best use of adalimumab in daily practice. Mod Rheumatol. 2013;23:466-77.

172. Koike T, Harigai M, Inokuma S, Ishiguro N, Ryu J, Takeuchi T, Tanaka Y, Yamanaka H, Fujii K, Yoshinaga T, Freundlich B, Suzukawa M. Postmarketing surveillance of safety and effectiveness of etanercept in Japanese patients with rheumatoid arthritis. Mod Rheumatol. 2011;21:34351.

173. Wolfe F, Caplan L, Michaud K. Rheumatoid arthritis treatment and the risk of severe interstitial lung disease. Scand J Rheumatol. 2007;36:172-8.

174. Shidara K, Hoshi D, Inoue E, Yamada T, Nakajima A, Taniguchi A, Hara M, Momohara S, Kamatani N, Yamanaka H. Incidence of and risk factors for interstitial pneumonia in patients with rheumatoid arthritis in a large Japanese observational cohort, IORRA. Mod Rheumatol. 2010;20:280-6.

175.Pérez-Alvarez R, Pérez-de-Lis M, Díaz-Lagares C, Pego-Reigosa JM, Retamozo S, Bové A, BritoZerón P, Bosch X, Ramos-Casals M. Interstitial lung disease induced or exacerbated by TNF-targeted 
therapies: analysis of 122 cases. Semin Arthritis Rheum. 2011;41:256-64.

176. Hadjinicolaou AV, Nisar MK, Bhagat S, Parfrey H, Chilvers ER, Ostör AJ. Non-infectious pulmonary complications of newer biological agents for rheumatic diseases - a systematic literature review. Rheumatology (Oxford). 2011;50:2297-305.

177.Pearce F, Johnson SR, Courtney P. Interstitial lung disease following certolizumab pegol. Rheumatology (Oxford). 2012;51:578-80.

178. Glaspole IN, Hoy RF, Ryan PF. A case of certolizumab-induced interstitial lung disease in a patient with rheumatoid arthritis. Rheumatology (Oxford). 2013;52:2302-4.

179.Dias OM, Pereira DA, Baldi BG, Costa AN, Athanazio RA, Kairalla RA, Carvalho CR. Adalimumab-induced acute interstitial lung disease in a patient with rheumatoid arthritis. J Bras Pneumol. 2014;40:77-81.

180. Tournadre A, Ledoux-Eberst J, Poujol D, Dubost JJ, Ristori JM, Soubrier M. Exacerbation of interstitial lung disease during etanercept therapy: Two cases. Joint Bone Spine. 2008;75:215-8.

181. Millar A, McKew J, Taggart A. Fatal fibrosing alveolitis with certolizumab. Rheumatology (Oxford). 2012;51:953-5.

182.Jeannin G, Mathieu S, Kemeny JL, Caillaud D, Soubrier M. Alveolar hemorrhage after infliximab therapy. Joint Bone Spine. 2010;77:189-90.

183. Khaja M, Menon L, Niazi M, Fuentes GD. Diffuse alveolar hemorrhage and acute respiratory distress syndrome during treatment of rheumatoid arthritis with etanercept. J Bronchology Interv Pulmonol. 2012;19:228-31.

184. Taki H, Kawagishi Y, Shinoda K, Hounoki H, Ogawa R, Sugiyama E, Tobe K. Interstitial pneumonitis associated with infliximab therapy without methotrexate treatment. Rheumatol Int. 2009;30:275-6.

185. Yamazaki H, Isogai S, Sakurai T, Nagasaka K. A case of adalimumab-associated interstitial pneumonia with rheumatoid arthritis. Mod Rheumatol. 2010;20:518-21.

186. Komiya K, Ishii H, Fujita N, Oka H, Iwata A, Sonoda H, Kadota J. Adalimumab-induced interstitial pneumonia with an improvement of preexisting rheumatoid arthritis-associated lung involvement. Intern Med. 2011;50:749-51.

187.Horai Y, Miyamura T, Shimada K, Takahama S, Minami R, Yamamoto M, Suematsu E. Eternacept for the treatment of patients with rheumatoid arthritis and concurrent interstitial lung disease. J Clin Pharm Ther. 2012;37:117-21.

188.Dascalu C, Mrejen-Shakin K, Bandagi S. Adalimumab-induced acute pneumonitis in a patient with rheumatoid arthritis. J Clin Rheumatol.
2010;16:172-4.

189. Aithal GP. Hepatotoxicity related to antirheumatic drugs. Nat Rev Rheumatol. 2011;7:139-50.

190. Cho SK, Oh IH, Park CK, Bae SC, Sung YK. Etanercept induced organizing pneumonia in a patient with rheumatoid arthritis. Rheumatol Int. 2012;32:1055-7.

191.Efe C. Drug induced autoimmune hepatitis and TNF- $\alpha$ blocking agents: is there a real relationship? Autoimmun Rev. 2013;12:337-9.

192. Ghabril M, Bonkovsky HL, Kum C, Davern T, Hayashi PH, Kleiner DE, Serrano J, Rochon J, Fontana RJ, Bonacini M. Liver injury from tumor necrosis factor- $\alpha$ antagonists: analysis of thirty-four cases. Clin Gastroenterol Hepatol. 2013;11:558-564.

193. Sokolove J, Strand V, Greenberg JD, Curtis JR, Kavanaugh A, Kremer JM, Anofrei A, Reed G, Calabrese L, Hooper M, Baumgartner S, Furst DE. Risk of elevated liver enzymes associated with TNF inhibitor utilisation in patients with rheumatoid arthritis. Ann Rheum Dis. 2010;69:1612-7.

194.van Denderen JC, Blom GJ, van der Horst-Bruinsma IE, Dijkmans BA, Nurmohamed MT. Elevated liver enzymes in patients with ankylosing spondylitis treated with etanercept. Clin Rheumatol. 2012;31:1677-82.

195. Titos Arcos JC, Hallal H, Robles M, Andrade RJ. Recurrent hepatotoxicity associated with etanercept and adalimumab but not with infliximab in a patient with rheumatoid arthritis. Rev Esp Enferm Dig. 2012;104:282-4.

196. Saleem G, Li SC, MacPherson BR, Cooper SM. Hepatitis with interface inflammation and $\operatorname{IgG}, \operatorname{IgM}$, and IgA anti-double-stranded DNA antibodies following infliximab therapy: comment on the article by Charles et al. Arthritis Rheum. 2001;44:1966-8.

197.Thiéfin G, Morelet A, Heurgué A, Diebold MD, Eschard JP. Infliximab-induced hepatitis: absence of cross-toxicity with etanercept. Joint Bone Spine. 2008;75:737-9.

198. Durel CA, Feurer E, Pialat JB, Berthoux E, Chapurlat RD, Confavreux CB. Etanercept may induce neurosarcoidosis in a patient treated for rheumatoid arthritis. BMC Neurol. 2013;13:212.

199. Nozaki K, Judson MA. Neurosarcoidosis. Curr Treat Options Neurol. 2013;15:492-504.

200. Vargas DL, Stern BJ. Neurosarcoidosis: diagnosis and management. Semin Respir Crit Care Med. 2010;31:419-27.

201.Almodóvar R, Izquierdo M, Zarco P, Javier Quirós F, Mazzucchelli R, Steen B. Pulmonary sarcoidosis in a patient with ankylosing spondylitis treated with infliximab. Clin Exp Rheumatol. 2007;25:99-101.

202.Gifre L, Ruiz-Esquide V, Xaubet A, Gómez-Puerta JA, Hernández MV, Sanmartí R. Lung sarcoidosis 
induced by TNF antagonists in rheumatoid arthritis: a case presentation and a literature review. Arch Bronconeumol. 2011;47:208-12.

203.Farah M, Al Rashidi A, Owen DA, Yoshida EM, Reid GD. Granulomatous hepatitis associated with etanercept therapy. J Rheumatol. 2008;35:349-51.

204.Korsten P, Sweiss NJ, Nagorsnik U, Niewold TB, Gröne HJ, Gross O, Müller GA. Drug-induced granulomatous interstitial nephritis in a patient with ankylosing spondylitis during therapy with adalimumab. Am J Kidney Dis. 2010;56:e17-21.

205. Setoguchi S, Schneeweiss S, Avorn J, Katz JN, Weinblatt ME, Levin R, Solomon DH. Tumor necrosis factor-alpha antagonist use and heart failure in elderly patients with rheumatoid arthritis. Am Heart J. 2008;156:336-41.

206.Curtis JR, Kramer JM, Martin C, Saag KG, Patkar N, Shatin D, Burgess M, Xie A, Braun MM. Heart failure among younger rheumatoid arthritis and Crohn's patients exposed to TNF-alpha antagonists. Rheumatology (Oxford). 2007;46:1688-93.

207. Wolfe F, Michaud K. Heart failure in rheumatoid arthritis: rates, predictors, and the effect of antitumor necrosis factor therapy. Am J Med. 2004;116:305-11.

208.Listing J, Strangfeld A, Kekow J, Schneider M, Kapelle A, Wassenberg S, Zink A. Does tumor necrosis factor alpha inhibition promote or prevent heart failure in patients with rheumatoid arthritis? Arthritis Rheum. 2008;58:667-77.

209.Lazzerini PE, Acampa M, Hammoud M, Maffei S, Capecchi PL, Selvi E, Bisogno S, Guideri F, Galeazzi M, Pasini FL. Arrhythmic risk during acute infusion of infliximab: a prospective, single-blind, placebo-controlled, crossover study in patients with chronic arthritis. J Rheumatol. 2008;35:1958-65.

210. Szekanecz Z, Kerekes G, Soltész P. Vascular effects of biologic agents in RA and spondyloarthropathies. Nat Rev Rheumatol. 2009;5:677-84.

211. Singh M, Diwan MM, Patel KC. A rare case of supraventricular tachycardia induced by Infliximab: a case report. Cases J. 2009;2:147.

212. Santos RC, Figueiredo VN, Martins LC, Moraes Cde H, Quinaglia T, Boer-Martins L, Ferreira-Melo SE, Yazbek MA, Bertolo M, Moreno H Jr. Infliximab reduces cardiac output in rheumatoid arthritis patients without heart failure. Rev Assoc Med Bras. 2012;58:698-702.

213. Synetos A, Toutouzas K, Aznaouridis K, Lerakis S, Stefanadis C. Dilated cardiomyopathy induced by anti-tumor necrosis factor. Int $\mathrm{J}$ Cardiol. 2009;132:e26-7.

214.Castro Rocha FA, Silva FS Jr. Reversible heart failure in a patient receiving etanercept for ankylosing spondylitis. J Clin Rheumatol. 2010;16:81-2.
215. Keystone EC. Does anti-tumor necrosis factor- $\alpha$ therapy affect risk of serious infection and cancer in patients with rheumatoid arthritis?: a review of longterm data. J Rheumatol. 2011;38:1552-62.

216. Bongartz T, Sutton AJ, Sweeting MJ, Buchan I, Matteson EL, Montori V. Anti-TNF antibody therapy in rheumatoid arthritis and the risk of serious infections and malignancies: systematic review and meta-analysis of rare harmful effects in randomized controlled trials. JAMA. 2006;295:2275-85.

217. Wong AK, Kerkoutian S, Said J, Rashidi H, Pullarkat ST. Risk of lymphoma in patients receiving antitumor necrosis factor therapy: a metaanalysis of published randomized controlled studies. Clin Rheumatol. 2012;31:631-6.

218. Franklin J, Lunt M, Bunn D, Symmons D, Silman A. Incidence of lymphoma in a large primary care derived cohort of cases of inflammatory polyarthritis. Ann Rheum Dis. 2006;65:617-22.

219. Smitten AL, Simon TA, Hochberg MC, Suissa S. A meta-analysis of the incidence of malignancy in adult patients with rheumatoid arthritis. Arthritis Res Ther. 2008;10:R45.

220.Moulis G, Sommet A, Béné J, Montastruc F, Sailler L, Montastruc JL, Lapeyre-Mestre M. Cancer risk of anti-TNF- $\alpha$ at recommended doses in adult rheumatoid arthritis: a meta-analysis with intention to treat and per protocol analyses. PLoS One. 2012; 7:e48991.

221. Wolfe F, Michaud K. Biologic treatment of rheumatoid arthritis and the risk of malignancy: analyses from a large US observational study. Arthritis Rheum. 2007;56:2886-95.

222. Askling J, Fahrbach K, Nordstrom B, Ross S, Schmid CH, Symmons D. Cancer risk with tumor necrosis factor alpha (TNF) inhibitors: meta-analysis of randomized controlled trials of adalimumab, etanercept, and infliximab using patient level data. Pharmacoepidemiol Drug Saf. 2011;20:119-30.

223.Dunk AA, Walt RP, Jenkins WJ, Sherlock SS. Diclofenac hepatitis. Br Med J (Clin Res Ed). 1982;284:1605-6.

224. Babany G, Pessayre D, Benhamou JP. Hepatitis caused by diclofenac. Gastroenterol Clin Biol. 1983;7:316.

225.Lascar G, Grippon P, Lévy VG. Acute fatal hepatitis during treatment with diclofenac (Voltarène). Gastroenterol Clin Biol. 1984;8:881-2.

226. Helfgott SM, Sandberg-Cook J, Zakim D, Nestler J. Diclofenac-associated hepatotoxicity. JAMA. 1990;264:2660-2.

227.Purcell P, Henry D, Melville G. Diclofenac hepatitis. Gut. 1991;32:1381-5.

228. Ouellette GS, Slitzky BE, Gates JA, Lagarde S, West AB. Reversible hepatitis associated with 
diclofenac. J Clin Gastroenterol. 1991;13:205-10.

229. Lewis JH. Hepatic toxicity of nonsteroidal antiinflammatory drugs. Clin Pharm. 1984;3:128-38.

230. Banks AT, Zimmerman HJ, Ishak KG, Harter JG. Diclofenac-associated hepatotoxicity: analysis of 180 cases reported to the Food and Drug Administration as adverse reactions. Hepatology. 1995;22:820-7.

231.Mazeika PK, Ford MJ. Chronic active hepatitis associated with diclofenac sodium therapy. Br J Clin Pract. 1989;43:125-6.

232. Schapira D, Bassan L, Nahir AM, Scharf Y. Diclofenac-induced hepatotoxicity. Postgrad Med J. 1986;62:63-5.

233. Breen EG, McNicholl J, Cosgrove E, McCabe J, Stevens FM. Fatal hepatitis associated with diclofenac. Gut. 1986;27:1390-3.

234. Sallie RW, McKenzie T, Reed WD, Quinlan MF, Shilkin KB. Diclofenac hepatitis. Aust N Z J Med. 1991;21:251-5.

235. Rostom A, Goldkind L, Laine L. Nonsteroidal antiinflammatory drugs and hepatic toxicity: a systematic review of randomized controlled trials in arthritis patients. Clin Gastroenterol Hepatol. 2005;3:489-98.

236.Laine L, Goldkind L, Curtis SP, Connors LG, Yanqiong Z, Cannon CP. How common is diclofenac-associated liver injury? Analysis of 17,289 arthritis patients in a long-term prospective clinical trial. Am J Gastroenterol. 2009;104:356-62.

237.Pilotto A, Seripa D, Franceschi M, Scarcelli C, Colaizzo D, Grandone E, Niro V, Andriulli A, Leandro G, Di Mario F, Dallapiccola B. Genetic susceptibility to nonsteroidal anti-inflammatory drug-related gastroduodenal bleeding: role of cytochrome P450 2C9 polymorphisms. Gastroenterology. 2007;133:465-71.

238. Chang CH, Chen HC, Lin JW, Kuo CW, Shau WY, Lai MS. Risk of hospitalization for upper gastrointestinal adverse events associated with nonsteroidal anti-inflammatory drugs: a nationwide case-crossover study in Taiwan. Pharmacoepidemiol Drug Saf. 2011;20:763-71.

239. Harirforoosh S, Asghar H, Jamali F Adverse Effects of Nonsteroidal Anti-inflammatory Drugs: An Update of Gastrointestinal, Cardiovascular and Renal Complications. J Pharm Pharm Sci. 2013;16(5):821-47.

240.Jamali F. Arthritis is associated with cardiovascular disease in the users of analgesics and nonsteroidal anti-inflammatory drugs. Arch Intern Med. 2007 Nov 26;167(21):2371-2.

241.Harirforoosh S, Jamali F. Renal adverse effects of non-steroidal anti-inflammatory drugs. Expert Opin Drug Saf. 2009;8(6):669-81

242.Neuman M, Nicar M. Apoptosis in ibuprofen- induced Stevens-Johnson syndrome. Transl Res. 2007;149:254-9.

243.Nanau RM, Neuman MG. Ibuprofen-induced hypersensitivity syndrome. Transl Res. 2010;155:275-93.

244.Nanau RM, Neuman MG. Ibuprofen: Associated Adverse Drug Reactions. In: Carter WC, Brown BR (Eds.). Ibuprofen: Clinical Pharmacology, Medical Uses and Adverse Effects. Nova Science Publishers. Hauppauge, NY. 2013:233-274. Chapter ID 13467. ISBN 978-1-62618-659-0. https://www.novapublishers.com/catalog/product_in fo.php?products_id $=41156$

245. Wilke WS, Mackenzie AH. Methotrexate therapy in rheumatoid arthritis. Current status. Drugs. 1986;32:103-13.

246. Kevat S, Ahern M, Hall P. Hepatotoxicity of methotrexate in rheumatic diseases. Med Toxicol Adverse Drug Exp. 1988;3:197-208.

247. Houtman PM, Jansen TL, Blanken R. Anaphylactic reaction in a patient with rheumatoid arthritis: a rare side effect of methotrexate with etanercept as a provoking factor? J Clin Rheumatol. 2006;12:321-2

248. Rabinovitz, Van Thiel DH. Hepatotoxicity of nonsteriodal anti-inflammaotry drugs. AM J Gastroenterol 1992; 87: 1696-1704.

249.Zimmerman HJ: Hepatotoxicity. Adverse Effects of Drugs and Other Chemicals on the Liver. 2nd Ed. Philadelphia Lippinott- Williams-Wilkins, 1999

250.Zimmerman HJ: Effects of aspirin and acetaminophen on the liver. Arch Intern Med 1981; 141:333-338.

251.Lee WM. Drug-induced hepatotoxicity. N Engl J Med 2003; 349:474-9.

252. Bissell DM, Gores GJ, Laskin, DL, Hoofnagle, JH. Drug-induced liver injury: mechanisms and test systems. Hepatology 2001; 33:1009-14.

253. Chitturi, S, George, J. Hepatotoxicity of commonly used drugs: nonsteroidal anti-inflammatory drugs, antihypertensives, antidiabetic agents, anticonvulsants, lipid-lowering agents, psychotropic drugs. Semin Liver Dis 2002; 22:169-86.

254.Newman, M, Auerbach, R, Feiner, H, et al. The role of liver biopsies in psoriatic patients receiving longterm methotrexate treatment: Improvement in liver abnormalities after cessation of treatment. Arch Dermatol 1989; 125:1218-25.

255. Fontana RJ, McCashland TM, Benner KJ, Appelman HD, Gunartanam N and the Acute Liver Failure study group. Acute liver failure associated with prolonged use of Bromfenac leading to liver transplantation. Liver Transplant and Surgery, 1999, $5,6,480-4$.

256. Clements PJ, Davis J. Cytotoxic drugs: their clinical application to the rheumatic diseases. Semin Arthritis Rheum. 1986;15:231-54. 
Table 1. Incidence of adverse events in clinical trials

\begin{tabular}{|c|c|c|c|}
\hline Trials and Patients & & Regimens & \\
\hline $\begin{array}{l}\text { ATTRACT (10) } \\
\text { Active RA patients } \\
\text { treated with MTX } \\
\text { for } \geq 3 \text { months }\end{array}$ & $\begin{array}{l}\text { MTX plus placebo injection, } \\
\text { through week } 30 \\
\text { Serious AEs: } 14 \text { of } 86(16.3 \%)\end{array}$ & $\begin{array}{l}\text { MTX plus IFX } 3 \mathrm{mg} / \mathrm{kg} \text { every } \\
8 \text { weeks, through week } 30 \\
\text { Serious AEs: } 8 \text { of } 89(9.0 \%) \\
\text { MTX plus IFX } 3 \mathrm{mg} / \mathrm{kg} \text { every } \\
4 \text { weeks, through week } 30 \\
\text { Serious AEs: } 11 \text { of } 86(12.8 \%)\end{array}$ & $\begin{array}{l}\text { MTX plus IFX } 10 \mathrm{mg} / \mathrm{kg} \text { every } \\
8 \text { weeks, through week } 30 \\
\text { Serious AEs: } 8 \text { of } 87(9.2 \%) \\
\text { MTX plus IFX } 10 \mathrm{mg} / \mathrm{kg} \text { every } \\
4 \text { weeks, through week } 30 \\
\text { Serious AEs: } 10 \text { of } 80(12.5 \%)\end{array}$ \\
\hline $\begin{array}{l}\text { ATTRACT (11) } \\
\text { Active RA patients } \\
\text { treated with MTX } \\
\text { for } \geq 3 \text { months }\end{array}$ & $\begin{array}{l}\text { MTX plus placebo injection, } \\
\text { through week } 54 \\
\text { Serious AEs: } 18 \text { of } 86(20.9 \%)\end{array}$ & $\begin{array}{l}\text { MTX plus IFX } 3 \mathrm{mg} / \mathrm{kg} \text { every } \\
8 \text { weeks, through week } 54 \\
\text { Serious AEs: } 10 \text { of } 88(11.4 \%) \\
\text { MTX plus IFX } 3 \mathrm{mg} / \mathrm{kg} \text { every } \\
4 \text { weeks, through week } 54 \\
\text { Serious AEs: } 14 \text { of } 86(16.3 \%)\end{array}$ & $\begin{array}{l}\text { MTX plus IFX } 10 \mathrm{mg} / \mathrm{kg} \text { every } \\
8 \text { weeks, through week } 54 \\
\text { Serious AEs: } 17 \text { of } 87(19.5 \%) \\
\text { MTX plus IFX } 10 \mathrm{mg} / \mathrm{kg} \text { every } \\
4 \text { weeks, through week } 54 \\
\text { Serious AEs: } 16 \text { of } 81(19.8 \%)\end{array}$ \\
\hline $\begin{array}{l}\text { Active-Controlled } \\
\text { Study of Patients } \\
\text { Receiving } \\
\text { Infliximab for the } \\
\text { Treatment of } \\
\text { Rheumatoid } \\
\text { Arthritis of Early } \\
\text { Onset Study (12) } \\
\text { Active RA } \leq 3 \text { years } \\
\text { duration }\end{array}$ & $\begin{array}{l}\text { MTX plus placebo injection, } \\
\text { through week } 54 \\
\text { Infusion reactions: } 20 \text { of } 291 \\
(6.9 \%) \\
\text { Serious AEs: } 32 \text { of } 291 \\
(11.0 \%) \\
\text { ANA: } 29 \text { of } 256(11.3 \%)\end{array}$ & $\begin{array}{l}\text { MTX plus IFX } 3 \mathrm{mg} / \mathrm{kg} \text { every } \\
8 \text { weeks, through week } 54 \\
\text { Infusion reactions: } 279 \text { of } 372 \\
(21.2 \%) \\
\text { Serious AEs: } 52 \text { of } 372(14.0 \%) \\
\text { ANA: } 118 \text { of } 298(39.6 \%)\end{array}$ & $\begin{array}{l}\text { MTX plus IFX } 6 \mathrm{mg} / \mathrm{kg} \text { every } \\
8 \text { weeks, through week } 54 \\
\text { Infusion reactions: } 56 \text { of } 377(14.8 \%) \\
\text { Serious AEs: } 51 \text { of } 377(13.5 \%) \\
\text { ANA: } 106 \text { of } 309(34.3 \%)\end{array}$ \\
\hline $\begin{array}{l}\text { START (13) } \\
\text { Active RA patients } \\
\text { treated with MTX } \\
\text { for } \geq 3 \text { months }\end{array}$ & $\begin{array}{l}\text { MTX plus placebo injection, } \\
\text { through week } 22(\mathrm{n}=361) \\
\text { AEs: } 239(66.2 \%) \\
\text { Serious AEs: } 27(7.5 \%) \\
\text { Serious infections: } 6(1.7 \%) \\
\end{array}$ & $\begin{array}{l}\text { MTX plus IFX } 3 \mathrm{mg} / \mathrm{kg} \text { every } \\
8 \text { weeks, through week } 22(\mathrm{n}=360) \\
\text { AEs: } 251(69.7 \%) \\
\text { Serious AEs: } 28(7.8 \%) \\
\text { Serious infections: } 6(1.7 \%) \\
\end{array}$ & $\begin{array}{l}\text { MTX plus IFX } 10 \mathrm{mg} / \mathrm{kg} \text { every } \\
8 \text { weeks, through week } 22(\mathrm{n}=361) \\
\text { AEs: } 261(72.3 \%) \\
\text { Serious AEs: } 27(7.5 \%) \\
\text { Serious infections: } 19(5.3 \%) \\
\end{array}$ \\
\hline $\begin{array}{l}\text { Ruperto et al. (14) } \\
\text { Active juvenile } \\
\text { rheumatoid arthritis } \\
\text { patients treated with } \\
\text { MTX for } \geq 3 \text { months }\end{array}$ & $\begin{array}{l}\text { MTX plus placebo, through } \\
\text { week } 14(\mathrm{n}=60) \\
\text { Infusion reactions: } 5(8.3 \%) \\
\text { AEs: } 49(81.7 \%) \\
\text { AEs leading to discontinuation } \\
\text { of study agent: } 1(1.7 \%) \\
\text { Serious AEs: } 3(5.0 \%) \\
\text { Infections: } 28(46.7 \%) \\
\text { Serious infections: } 2(3.3 \%)\end{array}$ & $\begin{array}{l}\text { MTX plus IFX } 3 \mathrm{mg} / \mathrm{kg} \text { every } \\
8 \text { weeks, through week } 52(\mathrm{n}=60) \\
\text { Infusion reactions: } 21(35.0 \%) \\
\text { AEs: } 58(96.7 \%) \\
\text { AEs leading to discontinuation of } \\
\text { study agent: } 2(3.3 \%) \\
\text { Serious AEs: } 19(31.7 \%) \\
\text { Infections: } 41(68.3 \%) \\
\text { Serious infections: } 5(8.3 \%) \\
\text { Presence of ADAs: } 20 \text { of } 53(37.7 \%) \\
\text { ALT } \geq 90 \text { IU/liter and elevations of } \\
\geq 100 \% \text { from baseline: } 3.3 \% \\
\text { Decreases in the neutrophil count } \\
\left(<1.5 \times 10^{3} \text { cells/ } \mu 1 \text { and decrease }\right. \\
\geq 33 \%): 1.7 \% \\
\text { ANA positivity (titer } \geq 1: 320): 8 \text { of } 54 \\
(14.8 \%) \\
\text { Presence of anti-dsDNA antibodies: } 7 \\
\text { of } 54(13.0 \%)\end{array}$ & $\begin{array}{l}\text { MTX plus IFX } 6 \mathrm{mg} / \mathrm{kg} \text { every } \\
8 \text { weeks, through week } 52(\mathrm{n}=60) \\
\text { Infusion reactions: } 10(17.5 \%) \\
\text { AEs: } 54(94.7 \%) \\
\text { AEs leading to discontinuation of study } \\
\text { agent: } 5(8.8 \%) \\
\text { Serious AEs: } 5(8.8 \%) \\
\text { Infections: } 37(64.9 \%) \\
\text { Serious infections: } 1(1.8 \%) \\
\text { Presence of ADAs: } 6 \text { of } 49(12.2 \%) \\
\text { ALT } \geq 90 \text { IU/liter and elevations of } \geq 100 \% \\
\text { from baseline: } 8.8 \% \\
\text { Decreases in the neutrophil count }(<1.5 \times \\
\left.10^{3} \text { cells/ } \mu 1 \text { and decrease } \geq 33 \%\right): 8.8 \% \\
\text { ANA positivity (titer } \geq 1: 320): 1 \text { of } 46 \\
\text { patients }(2.2 \%) \\
\text { Presence of anti-dsDNA antibodies: } 0 \text { of } \\
46(0.0 \%)\end{array}$ \\
\hline ASSERT (15) & $\begin{array}{l}\text { Placebo, through week } 24(\mathrm{n}=75 \\
\text { AEs: } 54(72.0 \%) \\
\text { Serious AEs: } 2(2.7 \%) \\
\text { Infusion reactions: } 7(9.3 \%) \\
\text { Infections: } 27(36.0 \%) \\
\text { Serious infections: } 0(0.0 \%) \\
\text { Increases in ALT: } 3(4.0 \%) \\
\text { Increases in AST: } 2(2.7 \%)\end{array}$ & $\begin{array}{l}\text { IFX } 5 \mathrm{mg} / \mathrm{kg} \\
\text { AEs: } 166(82 \\
\text { Serious AEs: } \\
\text { Infusion reac } \\
\text { Infections: } 86 \\
\text { Serious infec } \\
\text { Increases in } \\
\text { Increases in }\end{array}$ & $\begin{array}{l}\text { through week } 24(\mathrm{n}=202) \\
.2 \%) \\
7(3.5 \%) \\
\text { tions: } 22(10.9 \%) \\
6(42.6 \%) \\
\text { tions: } 2(1.0 \%) \\
\text { ALT: } 19(9.4 \%) \\
\text { AST: } 11(5.4 \%)\end{array}$ \\
\hline
\end{tabular}

Cont'd... 
Table 1 Cont'd.

\begin{tabular}{|c|c|c|c|c|c|}
\hline Trials and Patients & \multicolumn{5}{|c|}{ Regimens } \\
\hline $\begin{array}{l}\text { Enbrel ERA (16) } \\
\text { Early RA patients }\end{array}$ & $\begin{array}{l}\text { MTX plus placebo, through } \\
12 \text { months ( } \mathrm{n}=217) \\
\text { Injection site reactions: } 16 \\
(7.4 \%) \\
\text { Elevated AST: } 32 \% \\
\text { Elevated ALT: } 44 \% \\
\text { Neutropenia: } 8 \%\end{array}$ & \multicolumn{3}{|c|}{$\begin{array}{l}\text { ETN } 10 \mathrm{mg} \text { twice/week plus placebo, } \\
\text { through } 12 \text { months }(\mathrm{n}=208) \\
\text { Injection site reactions: } 63(30.3 \%) \\
(\mathrm{p}<0.05 \text { vs. MTX) }\end{array}$} & $\begin{array}{l}\text { ETN } 25 \mathrm{mg} \text { twice/we } \\
\text { through } 12 \text { months ( } \\
\text { Injection site reactior } \\
\text { (p<0.05 vs. MTX) } \\
\text { Elevated AST: } 16 \% \\
\text { Elevated ALT: } 24 \% \\
\text { Neutropenia: } 16 \%\end{array}$ \\
\hline $\begin{array}{l}\text { TEMPO (17) } \\
\text { Active RA patients }\end{array}$ & $\begin{array}{l}\text { MTX plus placebo, through } \\
12 \text { months (n=228) } \\
\text { AE: } 185(81.1 \%) \\
\text { Injection site reaction: } 4(1.8 \%) \\
\text { Nausea: } 73(32.0 \%) \\
\text { Rash: } 21(9.2 \%) \\
\text { Vomiting: } 26(11.4 \%) \\
\text { Infections: } 146(64.0 \%) \\
\text { Serious infections: } 10(4.4 \%) \\
\text { Grade } 3-4 \text { abnormalities in } \\
\text { hepatic enzymes levels: } 5 \\
(2.2 \%)\end{array}$ & \multicolumn{3}{|c|}{$\begin{array}{l}\text { ETN } 25 \text { mg twice/week plus placebo, } \\
\text { through } 12 \text { months }(\mathrm{n}=223) \\
\text { AE: } 192(86.1 \%) \\
\text { Injection site reaction: } 46(20.7 \%) \\
(\mathrm{p}<0.0001 \text { vs. MTX) } \\
\text { Nausea: } 22(9.9 \%)(\mathrm{p}<0.0001 \text { vs. MTX) } \\
\text { Rash: } 16(7.2 \%) \\
\text { Vomiting: } 7(3.1 \%)(\mathrm{p}<0.0001 \mathrm{vs.} \\
\text { MTX) } \\
\text { Infections: } 131(58.7 \%) \\
\text { Serious infections: } 10(4.5 \%) \\
\text { Grade 3-4 abnormalities in hepatic } \\
\text { enzymes levels: } 2(0.9 \%)\end{array}$} & $\begin{array}{l}\text { MTX plus ETN25 mg twice/week, } \\
\text { through } 12 \text { months }(\mathrm{n}=231) \\
\text { AE: } 1187(81.0 \%) \\
\text { Injection site reaction: } 23(10.0 \%) \\
(\mathrm{p}<0.0002 \text { vs. MTX, } \mathrm{p}=0.0017 \mathrm{vs.} \text { ETN) } \\
\text { Nausea: } 55(23.8 \%)(\mathrm{p}<0.0001 \text { vs. ETN) } \\
\text { Rash: } 23(10.0 \%) \\
\text { Vomiting: } 12(5.2 \%)(\mathrm{p}=0.0177 \mathrm{vs.} \\
\text { MTX) } \\
\text { Infections: } 154(66.7 \%) \\
\text { Serious infections: } 10(4.3 \%) \\
\text { Grade } 3-4 \text { abnormalities in hepatic } \\
\text { enzymes levels: } 2(0.9 \%)\end{array}$ \\
\hline $\begin{array}{l}\text { ADORE } \\
\text { Active R } \\
\geq 3 \text { month }\end{array}$ & \multicolumn{3}{|c|}{$\begin{array}{l}\text { ETN } 25 \mathrm{mg} \text { twice/week, through week } 16(\mathrm{n}=159) \\
\text { AEs: } 100(62.9 \%) \\
\text { AEs causing treatment withdrawal: } 13(8.2 \%) \\
\text { Serious AEs: } 8(5.0 \%) \\
\text { Infections: } 39(24.5 \%)\end{array}$} & \multicolumn{2}{|c|}{$\begin{array}{l}\text { MTX plus ETN25 mg twice/week, through week } 16 \text { (n } \\
=155) \\
\text { AEs: } 109(70.3 \%) \\
\text { AEs causing treatment withdrawal: } 9(5.8 \%) \\
\text { Serious AEs: } 7(4.5 \%) \\
\text { Infections: } 50(32.3 \%)\end{array}$} \\
\hline $\begin{array}{l}\text { COMET (19) } \\
\text { Moderate to severe } \\
\text { MTX-naïve RA }\end{array}$ & \multirow{2}{*}{\multicolumn{3}{|c|}{ 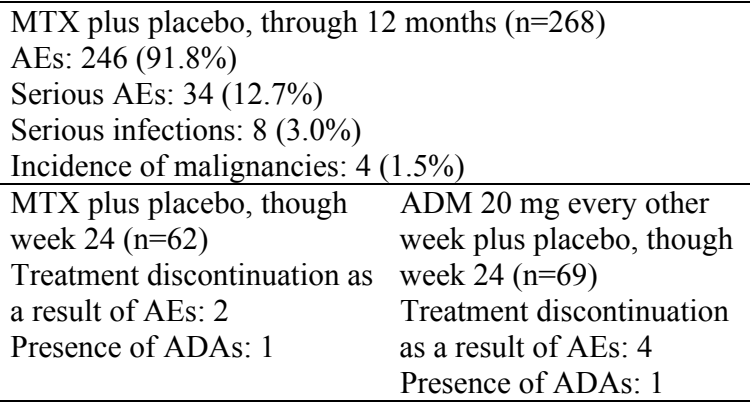 }} & \multicolumn{2}{|c|}{$\begin{array}{l}\text { MTX plus ETN25 mg twice/week, through } 12 \text { months } \\
(\mathrm{n}=274) \\
\text { AEs: } 247(90.1 \%) \\
\text { Serious AEs: } 33(12.0 \%) \\
\text { Serious infections: } 5(1.8 \%)\end{array}$} \\
\hline $\begin{array}{l}\text { ARMAI } \\
\text { Active } R \\
\text { receivin } \\
\text { stable do } \\
\text { months }\end{array}$ & & & & $\begin{array}{l}\text { ADM } 40 \text { mg every other } \\
\text { week plus placebo, though } \\
\text { week } 24 \text { ( } \mathrm{n}=67) \\
\text { Treatment discontinuation } \\
\text { as a result of AEs: } 0 \\
\text { Presence of ADAs: } 0\end{array}$ & $\begin{array}{ll}\text { every other } & \text { ADM } 80 \text { mg every other } \\
\text { cebo, though } & \text { week plus placebo, though } \\
\text { 7) } & \text { week } 24(\mathrm{n}=73) \\
\text { continuation } & \text { Treatment discontinuation } \\
\text { AEs: } 0 & \text { as a result of AEs: } 1 \\
\text { DAs: } 0 & \text { Presence of ADAs: } 1\end{array}$ \\
\hline $\begin{array}{l}\text { RAPID } 1 \\
\text { Active R } \\
\text { receiving } \\
\text { stable dos } \\
\text { months }\end{array}$ & \multicolumn{2}{|c|}{$\begin{array}{l}\text { MTX plus placebo injection, through } \\
\text { week } 24 \text { (events per } 100 \text { patient-years, } \\
\mathrm{n}=199 \text { ) } \\
\text { AEs: } 125.9 \\
\text { AEs related to study drug: } 54.7 \\
\text { Serious AEs: } 12.0\end{array}$} & \multicolumn{2}{|c|}{$\begin{array}{l}\text { MTX plus CZP } 200 \mathrm{mg} \text {, through } \\
\text { week } 24 \text { (events per } 100 \text { patient- } \\
\text { years, } \mathrm{n}=392 \text { ) } \\
\text { AEs: } 96.6 \\
\text { AEs related to study drug: } 55.1 \\
\text { Serious AEs: } 14.8\end{array}$} & $\begin{array}{l}\text { MTX plus CZP } 400 \mathrm{mg} \text {, through } \\
\text { week } 24 \text { (events per } 100 \text { patient- } \\
\text { years, } \mathrm{n}=389 \text { ) } \\
\text { AEs: } 94.5 \\
\text { AEs related to study drug: } 52.7 \\
\text { Serious AEs: } 15.2\end{array}$ \\
\hline $\begin{array}{l}\text { RAPID } 2(22) \\
\text { Active RA patic } \\
\text { receiving MTX } \\
\text { stable dose for } \\
\text { months }\end{array}$ & \multicolumn{4}{|c|}{$\begin{array}{ll}\begin{array}{l}\text { MTX plus placebo injection, through } \\
\text { week } 24(\mathrm{n}=125)\end{array} & \begin{array}{l}\text { MTX plus placebo injection, th } \\
\text { week } 24(\mathrm{n}=248)\end{array} \\
\text { Treatment-emergent AEs: } 66(52.8 \%) & \begin{array}{l}\text { Treatment-emergent AEs: } 139 \\
\text { Infections: } 26(20.8 \%)\end{array} \\
\text { Serious AEs: } 4(3.2 \%) & \text { Infections: } 69(27.8 \%) \\
\text { Serious infections: } 0(0.0 \%) & \text { Serious AEs: } 18(7.3 \%) \\
\text { AEs leading to withdrawal of } & \text { Serious infections: } 8(3.2 \%) \\
\text { treatment: } 2(1.6 \%) & \text { AEs leading to withdrawal of } \\
& \text { treatment: } 12(4.8 \%)\end{array}$} & $\begin{array}{l}\text { MTX plus placebo injection, thror } \\
\text { week } 24(\mathrm{n}=246) \\
\text { Treatment-emergent AEs: } 125 \\
(50.8 \%) \\
\text { Infections: } 53(21.5 \%) \\
\text { Serious AEs: } 18(7.3 \%) \\
\text { Serious infections: } 6(2.4 \%)\end{array}$ \\
\hline $\begin{array}{l}\text { FAST4WARD }(23) \\
\text { Active RA patients } \\
\text { who have failed } \geq 1 \\
\text { DMARDs }\end{array}$ & \multicolumn{3}{|c|}{$\begin{array}{l}\text { Placebo, through week } 24(\mathrm{n}=109) \\
\text { AEs: } 63(57.8 \%) \\
\text { Serious AEs: } 3(2.8 \%) \\
\text { Serious infections: } 0(0.0 \%) \\
\text { AEs leading to withdrawal: } 2(1.8 \%)\end{array}$} & \multicolumn{2}{|c|}{$\begin{array}{l}\text { CZP } 400 \mathrm{mg} \text {, through week } 24(\mathrm{n}=111 \\
\text { AEs: } 84(75.7 \%) \\
\text { Serious AEs: } 8(7.2 \%) \\
\text { Serious infections: } 2(1.8 \%) \\
\text { AEs leading to withdrawal: } 5(4.5 \%)\end{array}$} \\
\hline
\end{tabular}


Table 1 Cont'd.

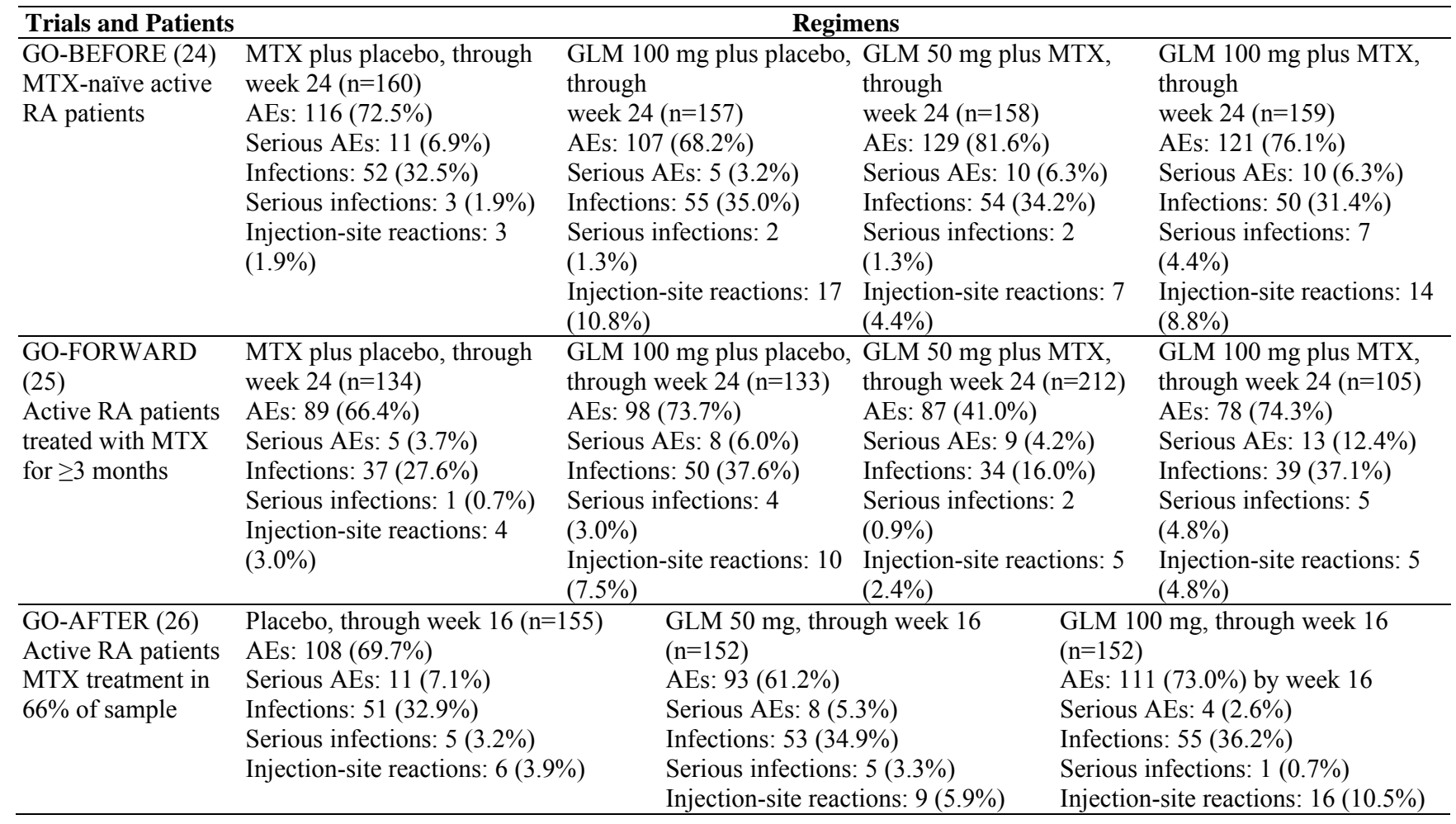


Table 2. Infusion reactions

\begin{tabular}{|c|c|c|c|c|c|c|c|}
\hline $\begin{array}{l}\text { Refer- } \\
\text { ence }\end{array}$ & $\begin{array}{c}\text { Patient } \\
\text { Conditions }\end{array}$ & Treatment & $\begin{array}{l}\text { Course of } \\
\text { Reaction }\end{array}$ & $\begin{array}{l}\text { Presentation of } \\
\text { Symptoms }\end{array}$ & Diagnosis & $\begin{array}{c}\text { Techniques to } \\
\text { Validate } \\
\text { Diagnosis }\end{array}$ & $\begin{array}{l}\text { Management of } \\
\text { Symptoms }\end{array}$ \\
\hline (72) & RA & IFX & Cutaneous & $\begin{array}{l}\text { Symptoms recurrent } \\
\text { while on IFX }\end{array}$ & Atopic dermatitis & $\begin{array}{l}\text { Physical } \\
\text { examination }\end{array}$ & $\begin{array}{l}\text { Hydrocortisone and } \\
\text { tacrolimus } \\
\text { IFX not discontinued }\end{array}$ \\
\hline (73) & RA & IFX & Cutaneous & $\begin{array}{l}\text { Symptoms after } 17 \\
\text { months of IFX }\end{array}$ & $\begin{array}{l}\text { Recurrent atopic } \\
\text { dermatitis }\end{array}$ & $\begin{array}{l}\text { Physical } \\
\text { examination }\end{array}$ & $\begin{array}{l}\text { Triamcinolone } \\
\text { IFX not discontinued }\end{array}$ \\
\hline (74) & $\begin{array}{l}\text { Long-standing } \\
\text { RA with } \\
\text { multiple drug } \\
\text { intolerances }\end{array}$ & $\begin{array}{l}\text { IFX + MTX + } \\
\text { prednisone }\end{array}$ & Cutaneous & $\begin{array}{l}\text { Within } 30 \text { min of } \\
\text { each infusion }\end{array}$ & IFX intolerance & $\begin{array}{l}\text { Physical } \\
\text { examination }\end{array}$ & $\begin{array}{l}\text { Diphenhydramine } \\
\text { IFX discontinued }\end{array}$ \\
\hline$(75)$ & RA & ETN & $\begin{array}{l}\text { Cutaneous, } \\
\text { swelling and } \\
\text { tachycardia }\end{array}$ & $\begin{array}{l}\text { After } 4 \text { months of } \\
\text { ETN }\end{array}$ & Angioedema & $\begin{array}{l}\text { Physical } \\
\text { examination }\end{array}$ & $\begin{array}{l}\text { Adrenaline, } \\
\text { antihistaminic and } \\
\text { methylprednisolone } \\
\text { ETN discontinued }\end{array}$ \\
\hline (76) & $\mathrm{AS}$ & ETN & $\begin{array}{l}\text { Cutaneous } \\
\text { and swelling }\end{array}$ & $\begin{array}{l}\text { After } 22^{\text {nd }} \text { infusion of } \\
\text { ETN } \\
\text { Previous symptoms } \\
\text { on ADM }\end{array}$ & $\begin{array}{l}\text { Injection-site } \\
\text { reaction }\end{array}$ & $\begin{array}{l}\text { Intradermal } \\
\text { testing } \\
\text { supporting } \\
\text { IgE-mediated } \\
\text { reaction }\end{array}$ & ETN desensitization \\
\hline (77) & AS & ETN & Cutaneous & $\begin{array}{l}\text { After } 6 \text { months of } \\
\text { ETN }\end{array}$ & $\begin{array}{l}\text { Urticaria } \\
\text { pigmentosa }\end{array}$ & Histology & $\begin{array}{l}\text { No treatment } \\
\text { ETN discontinued }\end{array}$ \\
\hline (78) & RA & $\begin{array}{l}\text { ETN + } \\
\text { DMARDs }\end{array}$ & $\begin{array}{l}\text { Cutaneous } \\
\text { and swelling }\end{array}$ & $\begin{array}{l}\text { After several months } \\
\text { of ETN }\end{array}$ & $\begin{array}{l}\text { Allergy and } \\
\text { anaphylaxis }\end{array}$ & $\begin{array}{l}\text { Physical } \\
\text { examination }\end{array}$ & $\begin{array}{l}\text { Diphenhydramine, } \\
\text { epinephrine and } \\
\text { corticosteroids } \\
\text { ETN discontinued }\end{array}$ \\
\hline (79) & RA & $\mathrm{ADM}$ & $\begin{array}{l}\text { Cutaneous, } \\
\text { swelling, } \\
\text { asthma and } \\
\text { hypotension }\end{array}$ & $\begin{array}{l}\text { After } 11^{\text {th }} \text { infusion of } \\
\text { ADM } \\
\text { Previous symptoms } \\
\text { on ETN and after } \\
\text { 10th infusion } \\
\text { of ADM }\end{array}$ & $\begin{array}{l}\text { Anaphylactic } \\
\text { reaction }\end{array}$ & $\begin{array}{l}\text { Physical } \\
\text { examination }\end{array}$ & $\begin{array}{l}\text { Corticosteroids and } \\
\text { antihistamines } \\
\text { ADM discontinued }\end{array}$ \\
\hline (80) & $\begin{array}{l}\text { RF-positive } \\
\text { RA }\end{array}$ & $\begin{array}{l}\text { IFX }+ \\
\text { prednisolone }\end{array}$ & $\begin{array}{l}\text { Cutaneous } \\
\text { and } \\
\text { eosinophilia }\end{array}$ & After 9 years of IFX & $\begin{array}{l}\text { Intermittent } \\
\text { pruritic rash } \\
\text { (Wells' } \\
\text { syndrome) }\end{array}$ & $\begin{array}{l}\text { Punch biopsy } \\
\text { Histology }\end{array}$ & $\begin{array}{l}\text { Prednisolone } \\
\text { IFX not discontinued }\end{array}$ \\
\hline (81) & $\begin{array}{l}\text { Long-standing } \\
\text { ANA-positive } \\
\text { JIA }\end{array}$ & $\mathrm{ETN}+\mathrm{MTX}$ & $\begin{array}{l}\text { Cutaneous } \\
\text { and swelling }\end{array}$ & $\begin{array}{l}\text { After } 5^{\text {th }} \text { weekly } \\
\text { ETN injection }\end{array}$ & Anaphylaxis & $\begin{array}{l}\text { Physical } \\
\text { examination }\end{array}$ & ETN discontinued \\
\hline$\overline{(81)}$ & $\begin{array}{l}\text { ANA- } \\
\text { positive, } \\
\text { HLA-B27- } \\
\text { positive } \\
\text { enthesitis- } \\
\text { related JIA }\end{array}$ & ETN & $\begin{array}{l}\text { Cutaneous, } \\
\text { swelling and } \\
\text { dyspnea }\end{array}$ & $\begin{array}{l}\text { Within minutes of } 3^{\text {rd }} \\
\text { ETN injection }\end{array}$ & Anaphylaxis & $\begin{array}{l}\text { Physical } \\
\text { examination }\end{array}$ & $\begin{array}{l}\text { Antihistamines and } \\
\text { prednisone } \\
\text { ETN discontinued }\end{array}$ \\
\hline (82) & $\mathrm{AS}$ & IFX & $\begin{array}{l}\text { Cutaneous } \\
\text { and dyspnea } \\
\text { Cardiopulmo } \\
\text { n-ary arrest }\end{array}$ & $\begin{array}{l}\text { After } 2^{\text {nd }} \text { infusion of } \\
\text { IFX }\end{array}$ & $\begin{array}{l}\text { Severe } \\
\text { anaphylaxis }\end{array}$ & $\begin{array}{l}\text { Electrocardio- } \\
\text { gram }\end{array}$ & $\begin{array}{l}\text { Treated for anaphylaxis } \\
\text { Discontinued }\end{array}$ \\
\hline$(83)$ & $\begin{array}{l}\text { RF-negative } \\
\text { RA }\end{array}$ & $\mathrm{ADM}+\mathrm{MTX}$ & $\begin{array}{l}\text { Cutaneous, } \\
\text { swelling and } \\
\text { eosinophilia }\end{array}$ & $\begin{array}{l}\text { After } 2 \text { years of } \\
\text { ADM }\end{array}$ & $\begin{array}{l}\text { Lymphocytic } \\
\text { hypereosinophilia }\end{array}$ & Skin biopsy & $\begin{array}{l}\text { Prednisone and imatinib } \\
\text { mesylate } \\
\text { ADM and MTX } \\
\text { discontinued }\end{array}$ \\
\hline
\end{tabular}


Table 3. Immune-mediated and autoimmune adverse events

\begin{tabular}{|c|c|c|c|c|c|c|c|}
\hline $\begin{array}{c}\text { Refer- } \\
\text { ence }\end{array}$ & $\begin{array}{c}\text { Patient } \\
\text { Conditions }\end{array}$ & Treatment & $\begin{array}{l}\text { Course of } \\
\text { Reaction }\end{array}$ & $\begin{array}{l}\text { Presentation of } \\
\text { Symptoms }\end{array}$ & Diagnosis & $\begin{array}{l}\text { Techniques to } \\
\text { Validate } \\
\text { Diagnosis }\end{array}$ & $\begin{array}{l}\text { Management of } \\
\text { Symptoms }\end{array}$ \\
\hline$(86)$ & $\begin{array}{l}\text { RF-positive severe } \\
\text { RA }\end{array}$ & $\begin{array}{l}\text { ETN + } \\
\text { DMARDs }\end{array}$ & Cutaneous & $\begin{array}{l}\text { After } 2 \text { months of } \\
\text { ETN }\end{array}$ & $\begin{array}{l}\text { Lichenoid } \\
\text { eruption }\end{array}$ & Skin biopsy & $\begin{array}{l}\text { Mometasone fuorate } \\
\text { ETN not } \\
\text { discontinued }\end{array}$ \\
\hline (87) & $\begin{array}{l}\text { JIA and Crohn's } \\
\text { disease }\end{array}$ & IFX & Cutaneous & $\begin{array}{l}\text { After } 4 \text { years of } \\
\text { IFX }\end{array}$ & $\begin{array}{l}\text { Lichenoid } \\
\text { dermatitis }\end{array}$ & Skin biopsy & $\begin{array}{l}\text { corticosteroids and } \\
\text { emollients, IFX } \\
\text { discontinued }\end{array}$ \\
\hline$(88)$ & RA & $\begin{array}{l}\text { ETN + } \\
\text { MTX }\end{array}$ & Cutaneous & $\begin{array}{l}\text { After } 1 \text { year of } \\
\text { ETN }\end{array}$ & Lichen planus & Punch biopsy & $\begin{array}{l}\text { Ciprofloxacin and } \\
\text { steroids } \\
\text { ETN discontinued }\end{array}$ \\
\hline (89) & $\begin{array}{l}\text { RA and secondary } \\
\text { amyloidosis }\end{array}$ & $\begin{array}{l}\text { ETN }+ \\
\text { DMARDs }\end{array}$ & $\begin{array}{l}\text { Cutaneous and } \\
\text { leukocytosis }\end{array}$ & $\begin{array}{l}\text { After } 1 \text { week of } \\
\text { ETN (3 infusions) }\end{array}$ & $\begin{array}{l}\text { Cutaneous } \\
\text { vasculitis }\end{array}$ & Skin biopsy & $\begin{array}{l}\text { Prednisolone } \\
\text { IFX discontinued }\end{array}$ \\
\hline (89) & $\begin{array}{l}\text { RA and secondary } \\
\text { amyloidosis }\end{array}$ & $\begin{array}{l}\text { IFX }+ \\
\text { MTX and } \\
\text { bucillamine }\end{array}$ & $\begin{array}{l}\text { Cutaneous and } \\
\text { leukocytosis }\end{array}$ & $\begin{array}{l}\text { After } 6 \text { weeks of } \\
\text { IFX ( } 3 \text { infusions) }\end{array}$ & $\begin{array}{l}\text { Leukocytoclastic } \\
\text { vasculitis }\end{array}$ & Skin biopsy & $\begin{array}{l}\text { No treatment } \\
\text { IFX discontinued }\end{array}$ \\
\hline (89) & RA & $\begin{array}{l}\text { IFX+ } \\
\text { MTX }\end{array}$ & $\begin{array}{l}\text { Cutaneous and } \\
\text { leukocytosis }\end{array}$ & $\begin{array}{l}\text { After } 3 \text { weeks of } \\
\text { IFX ( } 2 \text { infusions) }\end{array}$ & $\begin{array}{l}\text { Leukocytoclastic } \\
\text { vasculitis }\end{array}$ & $\begin{array}{l}\text { Clinical } \\
\text { Skin biopsy not } \\
\text { performed }\end{array}$ & $\begin{array}{l}\text { Dexamethasone } \\
\text { ETN discontinued }\end{array}$ \\
\hline (87) & Long-standing JIA & IFX & Cutaneous & $\begin{array}{l}\text { After } 4 \text { years of } \\
\text { IFX }\end{array}$ & $\begin{array}{l}\text { Cutaneous } \\
\text { leukocytoclastic } \\
\text { vasculitis }\end{array}$ & Punch biopsy & $\begin{array}{l}\text { Systemic } \\
\text { corticosteroids } \\
\text { IFX discontinued }\end{array}$ \\
\hline$(90)$ & $\begin{array}{l}\text { HLA-B27-positive } \\
\text { AS }\end{array}$ & GLM & Cutaneous & $\begin{array}{l}\text { After } 2^{\text {nd }} \text { infusion } \\
\text { of GLM } \\
\text { Previous exposure } \\
\text { to ADM and ETN }\end{array}$ & $\begin{array}{l}\text { Leukocytoclastic } \\
\text { vasculitis }\end{array}$ & Skin biopsy & $\begin{array}{l}\text { Glucocorticoids } \\
\text { GLM discontinued }\end{array}$ \\
\hline (91) & RA & ETN & Cutaneous & $\begin{array}{l}\text { After } 12 \text { months of } \\
\text { ETN }\end{array}$ & $\begin{array}{l}\text { Cutaneous small- } \\
\text { vessel vasculitis }\end{array}$ & Skin biopsy & $\begin{array}{l}\text { Prednisone } \\
\text { ETN discontinued }\end{array}$ \\
\hline$(91)$ & RA & IFX & Cutaneous & $\begin{array}{l}\text { After } 6 \text { years of } \\
\text { IFX }\end{array}$ & $\begin{array}{l}\text { Cutaneous small- } \\
\text { vessel vasculitis }\end{array}$ & Skin biopsy & $\begin{array}{l}\text { Prednisone } \\
\text { IFX discontinued }\end{array}$ \\
\hline (91) & RA & IFX & Cutaneous & $\begin{array}{l}\text { After } 5 \text { years of } \\
\text { IFX }\end{array}$ & $\begin{array}{l}\text { Cutaneous small- } \\
\text { vessel vasculitis }\end{array}$ & Skin biopsy & $\begin{array}{l}\text { Prednisone } \\
\text { IFX discontinued }\end{array}$ \\
\hline (91) & RA & ETN & Peripheral nerves & $\begin{array}{l}\text { After } 3 \text { years of } \\
\text { ETN }\end{array}$ & $\begin{array}{l}\text { Peripheral nerve } \\
\text { vasculitis with } \\
\text { neuropathy }\end{array}$ & $\begin{array}{l}\text { Neuromuscular } \\
\text { biopsy }\end{array}$ & $\begin{array}{l}\text { Prednisone and } \\
\text { cyclophosphamide } \\
\text { ETN discontinued }\end{array}$ \\
\hline (92) & $\begin{array}{l}\text { RF-negative } \\
\text { erosive RA }\end{array}$ & GLM & $\begin{array}{l}\text { Pulmonary and } \\
\text { haemoptysis }\end{array}$ & $\begin{array}{l}\text { After } 3 \text { years of } \\
\text { GLM }\end{array}$ & $\begin{array}{l}\text { Wegener's } \\
\text { granulomatosis }\end{array}$ & $\begin{array}{l}\text { Chest X-rays } \\
\text { CT scan } \\
\text { Bronchoscopy } \\
\end{array}$ & $\begin{array}{l}\text { Prednisone } \\
\text { GLM discontinued }\end{array}$ \\
\hline (93) & $\begin{array}{l}\text { HLA-B27- } \\
\text { negative AS }\end{array}$ & ETN & $\begin{array}{l}\text { Cutaneous, joint } \\
\text { pain and acute } \\
\text { renal failure }\end{array}$ & $\begin{array}{l}\text { After } 6 \text { months of } \\
\text { ETN }\end{array}$ & $\begin{array}{l}\text { Henoch- } \\
\text { Schönlein } \\
\text { purpura }\end{array}$ & $\begin{array}{l}\text { Skin biopsy } \\
\text { Urinalysis } \\
\text { Renal biopsy } \\
\text { Immuno- } \\
\text { fluorescence }\end{array}$ & $\begin{array}{l}\text { Methylprednisone, } \\
\text { prednisone, then } \\
\text { corticosteroids } \\
\text { ETN discontinued }\end{array}$ \\
\hline (94) & RA & $\begin{array}{l}\text { IFX }+ \\
\text { prednisone }\end{array}$ & $\begin{array}{l}\text { Cutaneous and } \\
\text { eosinophilia }\end{array}$ & $\begin{array}{l}\text { After } 4 \text { months of } \\
\text { IFX }\end{array}$ & $\begin{array}{l}\text { Subacute prurigo } \\
\text { with eosinophilia }\end{array}$ & Skin biopsy & $\begin{array}{l}\text { Systemic } \\
\text { corticosteroids } \\
\text { IFX discontinued }\end{array}$ \\
\hline$(95)$ & Long-standing RA & $\begin{array}{l}\mathrm{ADM}+ \\
\mathrm{MTX}+ \\
\text { prednisone } \\
\end{array}$ & Cutaneous & $\begin{array}{l}\text { After } 5^{\text {th }} \mathrm{ADM} \\
\text { injection }\end{array}$ & $\begin{array}{l}\text { Stevens-Johnson } \\
\text { syndrome }\end{array}$ & $\begin{array}{l}\text { Clinical } \\
\text { Biopsy was } \\
\text { refused }\end{array}$ & $\begin{array}{l}\text { Hydrocortisone then } \\
\text { prednisone } \\
\text { ADM discontinued }\end{array}$ \\
\hline$(96)$ & RA & ETN & Cutaneous & $\begin{array}{l}\text { Symptoms after } \\
2^{\text {nd }} \text { infusion of } \\
\text { ETN }\end{array}$ & $\begin{array}{l}\text { Pustular } \\
\text { dermatitis }\end{array}$ & Skin biopsy & $\begin{array}{l}\text { Corticosteroids } \\
\text { ETN discontinued }\end{array}$ \\
\hline
\end{tabular}


Table 3 Cont'd.

\begin{tabular}{|c|c|c|c|c|c|c|c|}
\hline $\begin{array}{l}\text { Refer- } \\
\text { ence }\end{array}$ & $\begin{array}{c}\text { Patient } \\
\text { Conditions }\end{array}$ & Treatment & $\begin{array}{l}\text { Course of } \\
\text { Reaction }\end{array}$ & $\begin{array}{l}\text { Presentation of } \\
\text { Symptoms }\end{array}$ & Diagnosis & $\begin{array}{c}\text { Techniques to } \\
\text { Validate } \\
\text { Diagnosis } \\
\end{array}$ & $\begin{array}{l}\text { Management of } \\
\text { Symptoms }\end{array}$ \\
\hline (97) & RF-positive RA & ETN & $\begin{array}{l}\text { Cutaneous and } \\
\text { dyspnea }\end{array}$ & $\begin{array}{l}\text { After } 5 \text { months of } \\
\text { sequential ADM } \\
\text { followed by ETN }\end{array}$ & Dermatomyositis & Punch biopsy & $\begin{array}{l}\text { Mycophenolate } \\
\text { mofetil, } \\
\text { methylprednisolone } \\
\text { and corticosteroids } \\
\text { ETN discontinued }\end{array}$ \\
\hline (97) & RF-positive RA & ETN & Cutaneous & $\begin{array}{l}\text { After } 2 \text { years of } \\
\text { ETN }\end{array}$ & Dermatomyositis & $\begin{array}{l}\text { Punch biopsy } \\
\text { Autoantibodies }\end{array}$ & $\begin{array}{l}\text { Cobetasol and } \\
\text { prednisone } \\
\text { ETN discontinued }\end{array}$ \\
\hline (97) & $\begin{array}{l}\text { RF-negative } \\
\text { inflammatory } \\
\text { arthritis }\end{array}$ & $\begin{array}{l}\text { ADM + } \\
\text { MTX }\end{array}$ & $\begin{array}{l}\text { Cutaneous, } \\
\text { muscle edema } \\
\text { and } \\
\text { photosensitivity }\end{array}$ & $\begin{array}{l}\text { After } 4 \text { months of } \\
\text { ADM }\end{array}$ & Dermatomyositis & $\begin{array}{l}\text { Punch biopsy } \\
\text { Electromyo- } \\
\text { graphy } \\
\text { Autoantibodies }\end{array}$ & $\begin{array}{l}\text { Prednisone and } \\
\text { mepacrine } \\
\text { ADM discontinued }\end{array}$ \\
\hline (97) & $\begin{array}{l}\text { RF-positive RA } \\
\text { and history of } \\
\text { dermatomyositis }\end{array}$ & $\mathrm{ADM}$ & $\begin{array}{l}\text { Cutaneous and } \\
\text { pulmonary }\end{array}$ & $\begin{array}{l}\text { After } 2 \text { months of } \\
\text { ADM }\end{array}$ & Dermatomyositis & $\begin{array}{l}\text { Pulmonary } \\
\text { function tests }\end{array}$ & $\begin{array}{l}\text { Prednisone and } \\
\text { cyclophosphamide } \\
\text { ADM discontinued }\end{array}$ \\
\hline (98) & Long-standing JIA & $\begin{array}{l}\text { ETN + } \\
\text { prednisone }\end{array}$ & $\begin{array}{l}\text { Cutaneous and } \\
\text { photosensitivity }\end{array}$ & $\begin{array}{l}\text { After } 2 \text { months of } \\
\text { weekly ETN } \\
\text { Previous } 10 \text { years } \\
\text { of sporadic ETN }\end{array}$ & $\begin{array}{l}\text { Dermatomyositis } \\
\text { Recurrence on } \\
\text { ADM }\end{array}$ & Punch biopsy & $\begin{array}{l}\text { Prednisone } \\
\text { ETN discontinued }\end{array}$ \\
\hline (99) & $\begin{array}{l}\text { HLA-B27-positive } \\
\text { AS }\end{array}$ & $\mathrm{ADM}$ & Cutaneous & $\begin{array}{l}\text { Symptoms after } 12 \\
\text { months of ADM }\end{array}$ & Morphea & Skin biopsy & $\begin{array}{l}\text { Clobetasol } \\
\text { proprionate } \\
\text { ADM discontinued }\end{array}$ \\
\hline (102) & $\begin{array}{l}\text { ANA-positive, } \\
\text { andi-dsDNA } \\
\text { antibodies-positive } \\
\text { RA }\end{array}$ & IFX & $\begin{array}{l}\text { Photosensitivity, } \\
\text { arthritis and } \\
\text { serositis }\end{array}$ & $\begin{array}{l}\text { After } 10 \text { days of } \\
\text { IFX }\end{array}$ & $\begin{array}{l}\text { IFX systemic } \\
\text { lupus } \\
\text { erythematosus }\end{array}$ & Autoantibodies & IFX discontinued \\
\hline$(102)$ & $\begin{array}{l}\text { ANA-positive, } \\
\text { andi-dsDNA } \\
\text { antibodies-positive } \\
\text { RA }\end{array}$ & IFX & $\begin{array}{l}\text { Arthritis and } \\
\text { leukopenia }\end{array}$ & $\begin{array}{l}\text { After } 33 \text { months of } \\
\text { IFX }\end{array}$ & $\begin{array}{l}\text { IFX systemic } \\
\text { lupus } \\
\text { erythematosus }\end{array}$ & Autoantibodies & IFX discontinued \\
\hline$(102)$ & RA & IFX & $\begin{array}{l}\text { Arthritis, serositis } \\
\text { and hemolytic, } \\
\text { anemia with } \\
\text { reticulocytosis }\end{array}$ & $\begin{array}{l}\text { After } 12 \text { months of } \\
\text { IFX }\end{array}$ & $\begin{array}{l}\text { IFX systemic } \\
\text { lupus } \\
\text { erythematosus }\end{array}$ & Autoantibodies & IFX discontinued \\
\hline (102) & RA & IFX & Serositis & $\begin{array}{l}\text { After } 12 \text { months of } \\
\text { IFX }\end{array}$ & $\begin{array}{l}\text { IFX systemic } \\
\text { lupus } \\
\text { erythematosus }\end{array}$ & Autoantibodies & IFX discontinued \\
\hline (103) & $\begin{array}{l}\text { ANA-positive anti- } \\
\text { cyclic citrullinated } \\
\text { peptide antibodies- } \\
\text { positive RF- } \\
\text { negative RA }\end{array}$ & $\begin{array}{l}\mathrm{ADM}+ \\
\mathrm{MTX}\end{array}$ & Cutaneous & $\begin{array}{l}\text { After } 2^{\text {nd }} \text { ADM } \\
\text { infusion after a } 3 \\
\text { months gap } \\
\text { following } 2 \text { years } \\
\text { of ADM }\end{array}$ & $\begin{array}{l}\text { Drug-induced } \\
\text { cutaneous lupus } \\
\text { erythematosus }\end{array}$ & $\begin{array}{l}\text { Skin biopsy } \\
\text { Autoantibodies }\end{array}$ & $\begin{array}{l}\text { ADM discontinued } \\
\text { and MTX } \\
\text { maintained }\end{array}$ \\
\hline (104) & RA & ETN & Cutaneous & $\begin{array}{l}\text { After } 2 \text { months of } \\
\text { ETN } \\
\text { Previous } 3 \text { years of } \\
\text { ADM }\end{array}$ & $\begin{array}{l}\text { Drug-induced } \\
\text { subacute } \\
\text { cutaneous lupus- } \\
\text { like syndrome }\end{array}$ & $\begin{array}{l}\text { Skin biopsy } \\
\text { Autoantibodies }\end{array}$ & $\begin{array}{l}\text { Prednisone, } \\
\text { hydroxychloroquine } \\
\text { sulfate and } \\
\text { corticosteroids } \\
\text { ETN discontinued }\end{array}$ \\
\hline$(105)$ & $\begin{array}{l}\text { RF-positive severe } \\
\text { erosive RA }\end{array}$ & ETN & $\begin{array}{l}\text { Joint pain, } \\
\text { vasculitis and } \\
\text { lymphopenia }\end{array}$ & $\begin{array}{l}\text { After } 7 \text { months of } \\
\text { ETN }\end{array}$ & $\begin{array}{l}\text { Drug-induced } \\
\text { lupus }\end{array}$ & Autoantibodies & $\begin{array}{l}\text { Steroids } \\
\text { ETN discontinued }\end{array}$ \\
\hline (105) & RF-positive RA & ETN & Joint pain & $\begin{array}{l}\text { After } 3 \text { years of } \\
\text { ETN }\end{array}$ & $\begin{array}{l}\text { Drug-induced } \\
\text { lupus }\end{array}$ & Autoantibodies & $\begin{array}{l}\text { Methylprednisolone } \\
\text { ETN discontinued }\end{array}$ \\
\hline
\end{tabular}

Cont'd... 
Table 3 Cont'd.

\begin{tabular}{|c|c|c|c|c|c|c|c|}
\hline $\begin{array}{l}\text { Refer- } \\
\text { ence }\end{array}$ & $\begin{array}{c}\text { Patient } \\
\text { Conditions }\end{array}$ & Treatment & $\begin{array}{l}\text { Course of } \\
\text { Reaction }\end{array}$ & $\begin{array}{l}\text { Presentation of } \\
\text { Symptoms }\end{array}$ & Diagnosis & $\begin{array}{l}\text { Techniques to } \\
\text { Validate } \\
\text { Diagnosis }\end{array}$ & $\begin{array}{l}\text { Management of } \\
\text { Symptoms }\end{array}$ \\
\hline$\overline{(105)}$ & $\begin{array}{l}\text { ANA-positive RF- } \\
\text { positive RA }\end{array}$ & $\mathrm{ADM}$ & $\begin{array}{l}\text { Joint pain, } \\
\text { vasculitis and } \\
\text { lymphopenia }\end{array}$ & $\begin{array}{l}\text { After } 1 \text { year of } \\
\text { ADM }\end{array}$ & $\begin{array}{l}\text { Drug-induced } \\
\text { lupus }\end{array}$ & Autoantibodies & $\begin{array}{l}\text { Prednisolone } \\
\text { ADM discontinued }\end{array}$ \\
\hline$(106)$ & $\begin{array}{l}\text { ANA-positive RF- } \\
\text { negative } \\
\text { destructive RA }\end{array}$ & $\mathrm{ADM}$ & $\begin{array}{l}\text { Cutaneous, } \\
\text { muscle pain }\end{array}$ & $\begin{array}{l}\text { After } 8 \text { months of } \\
\text { ADM with } \\
\text { previous } 3 \text { years of } \\
\text { ETN }\end{array}$ & $\begin{array}{l}\text { Drug-induced } \\
\text { lupus } \\
\text { erythematosus }\end{array}$ & $\begin{array}{l}\text { Skin biopsy } \\
\text { Autoantibodies }\end{array}$ & $\begin{array}{l}\text { Corticosteroids } \\
\text { ADM discontinued }\end{array}$ \\
\hline (107) & $\begin{array}{l}\text { RA and } \\
\text { autoimmune } \\
\text { hepatitis }\end{array}$ & $\begin{array}{l}\text { IFX + AZA } \\
+ \\
\text { prednisone }\end{array}$ & Cutaneous & $\begin{array}{l}\text { After } 4 \text { months of } \\
\text { IFX }\end{array}$ & $\begin{array}{l}\text { Drug-induced } \\
\text { lupus-like } \\
\text { syndrome }\end{array}$ & $\begin{array}{l}\text { Skin biopsy } \\
\text { Colloidal iron } \\
\text { stain } \\
\text { Autoantibodies }\end{array}$ & $\begin{array}{l}\text { No treatment } \\
\text { IFX discontinued }\end{array}$ \\
\hline (108) & $\begin{array}{l}\text { ANA-positive RF- } \\
\text { negative HLA- } \\
\text { B27-positive AS }\end{array}$ & $\begin{array}{l}\text { IFX }+ \\
\text { DMARDs } \\
+ \text { cortico- } \\
\text { steroids }\end{array}$ & Cutaneous & $\begin{array}{l}\text { After } 4 \text { years of } \\
\text { IFX }\end{array}$ & $\begin{array}{l}\text { Drug-induced } \\
\text { chilblain lupus } \\
\text { erythematosus }\end{array}$ & $\begin{array}{l}\text { Skin biopsy } \\
\text { Autoantibodies }\end{array}$ & $\begin{array}{l}\text { Corticosteroids } \\
\text { IFX discontinued }\end{array}$ \\
\hline (109) & Active AS & IFX & $\begin{array}{l}\text { Thoracic pain ar } \\
\text { dyspnea }\end{array}$ & $\begin{array}{l}\text { After } 8 \text { months of } \\
\text { IFX }\end{array}$ & $\begin{array}{l}\text { Drug-induced } \\
\text { lupus-like } \\
\text { syndrome }\end{array}$ & Autoantibodies & $\begin{array}{l}\text { Methylprednisolone } \\
\text { IFX discontinued }\end{array}$ \\
\hline$(110)$ & Axial AS & IFX & $\begin{array}{l}\text { Joint pain and } \\
\text { swelling, and } \\
\text { leukocytosis }\end{array}$ & $\begin{array}{l}\text { After } 6^{\text {th }} \text { IFX } \\
\text { infusion }\end{array}$ & $\begin{array}{l}\text { Drug-induced } \\
\text { lupus } \\
\text { erythematosus }\end{array}$ & Autoantibodies & $\begin{array}{l}\text { Prednisolone } \\
\text { IFX discontinued }\end{array}$ \\
\hline$\overline{(111)}$ & $\begin{array}{l}\text { Severe RF- } \\
\text { negative RA }\end{array}$ & GLM & Cutaneous & $\begin{array}{l}\text { After } 16 \text { months of } \\
\text { GLM } \\
\text { Previous } 12 \text { weeks } \\
\text { of ETN and } 10 \\
\text { months of IFX }\end{array}$ & $\begin{array}{l}\text { Drug-induced } \\
\text { subacute } \\
\text { cutaneous lupus } \\
\text { erythematosus } \\
\text { aggravated by } \\
\text { sun exposure }\end{array}$ & $\begin{array}{l}\text { Skin biopsy } \\
\text { Autoantibodies }\end{array}$ & $\begin{array}{l}\text { Mometasone furoate } \\
\text { GLM discontinued }\end{array}$ \\
\hline (112) & Active RA & $\begin{array}{l}\text { IFX }+ \\
\text { lefluno- } \\
\text { mide }\end{array}$ & Cutaneous & $\begin{array}{l}\text { After } 6^{\text {th }} \text { IFX } \\
\text { infusion }\end{array}$ & $\begin{array}{l}\text { Drug-induced } \\
\text { discoid lupus } \\
\text { erythematos }\end{array}$ & $\begin{array}{l}\text { Skin biopsy } \\
\text { Autoantibodies }\end{array}$ & $\begin{array}{l}\text { Hydroxy- } \\
\text { chloroquine and } \\
\text { methylprednisolone } \\
\text { IFX discontinued }\end{array}$ \\
\hline (116) & RA & IFX & $\begin{array}{l}\text { Cutaneous and } \\
\text { leukocytosis }\end{array}$ & $\begin{array}{l}\text { After } 5 \text { weeks of } \\
\text { IFX }\end{array}$ & $\begin{array}{l}\text { Generalized } \\
\text { psoriasiform and } \\
\text { pustular eruption }\end{array}$ & Skin biopsy & $\begin{array}{l}\text { Prednisolone } \\
\text { IFX discontinued }\end{array}$ \\
\hline (117) & $\begin{array}{l}\text { Long-standing } \\
\text { HLA-B27-positive } \\
\text { AS and CD }\end{array}$ & $\mathrm{ADM}$ & Cutaneous & $\begin{array}{l}\text { After } 15 \text { months of } \\
\text { ADM }\end{array}$ & $\begin{array}{l}\text { New-onset } \\
\text { psoriasis }\end{array}$ & Punch biopsy & $\begin{array}{l}\text { Triamcinolone and } \\
\text { cetirizine } \\
\text { ADM discontinued }\end{array}$ \\
\hline$(117)$ & RF-positive RA & $\mathrm{ADM}$ & Cutaneous & $\begin{array}{l}\text { After } 3 \text { years of } \\
\text { ADM }\end{array}$ & $\begin{array}{l}\text { New-onset } \\
\text { psoriasis }\end{array}$ & Punch biopsy & $\begin{array}{l}\text { Fluocinonide and } \\
\text { cetirizine } \\
\text { ADM discontinued }\end{array}$ \\
\hline (118) & JIA and uveitis & $\mathrm{ADM}$ & Cutaneous & $\begin{array}{l}\text { After } 9 \text { months of } \\
\text { ADM }\end{array}$ & $\begin{array}{l}\text { Psoriasis with } \\
\text { severe scalp } \\
\text { involvement }\end{array}$ & Skin biopsy & $\begin{array}{l}\text { Multi-drug } \\
\text { dermatologic therapy } \\
\text { ADM discontinued }\end{array}$ \\
\hline (119) & $\begin{array}{l}\text { HLA-B27- } \\
\text { negative spondylo- } \\
\text { arthropathy }\end{array}$ & $\begin{array}{l}\text { GLM + } \\
\text { leflunomid } \\
\text { e }\end{array}$ & Cutaneous & $\begin{array}{l}\text { After } 2 \text { months of } \\
\text { GLM } \\
\text { Previous exposure } \\
\text { to IFX and GLM }\end{array}$ & $\begin{array}{l}\text { Bullae and } \\
\text { psoriasiform } \\
\text { hyperkeratosis }\end{array}$ & Skin biopsy & $\begin{array}{l}\text { No treatment } \\
\text { GLM discontinued }\end{array}$ \\
\hline (107) & RA & ETN & Cutaneous & $\begin{array}{l}\text { After } 4 \text { months of } \\
\text { ETN }\end{array}$ & $\begin{array}{l}\text { Palmoplantar } \\
\text { pustular psoriasis }\end{array}$ & Histology & $\begin{array}{l}\text { Phototherapy and } \\
\text { halobetasol } \\
\text { ETN discontinued }\end{array}$ \\
\hline (87) & JIA & $\begin{array}{l}\mathrm{ADM}+ \\
\text { leflunomid } \\
\mathrm{e}\end{array}$ & Cutaneous & $\begin{array}{l}\text { After } 10 \text { months of } \\
\text { ADM }\end{array}$ & $\begin{array}{l}\text { Palmoplantar } \\
\text { pustular psoriasis }\end{array}$ & Skin biopsy & $\begin{array}{l}\text { Steroids and vitamin } \\
\text { D } \\
\text { ADM discontinued }\end{array}$ \\
\hline
\end{tabular}

Cont'd... 
Table 3 Cont'd.

\begin{tabular}{|c|c|c|c|c|c|c|c|}
\hline $\begin{array}{l}\text { Refer- } \\
\text { ence }\end{array}$ & $\begin{array}{c}\text { Patient } \\
\text { Conditions }\end{array}$ & Treatment & $\begin{array}{l}\text { Course of } \\
\text { Reaction }\end{array}$ & $\begin{array}{l}\text { Presentation of } \\
\text { Symptoms }\end{array}$ & Diagnosis & $\begin{array}{l}\text { Techniques to } \\
\text { Validate } \\
\text { Diagnosis }\end{array}$ & $\begin{array}{l}\text { Management of } \\
\text { Symptoms }\end{array}$ \\
\hline (87) & $\begin{array}{l}\text { Long-standing JIA } \\
\text { and chronic } \\
\text { iridociclitis }\end{array}$ & $\begin{array}{l}\text { ETN + } \\
\text { MTX }\end{array}$ & Cutaneous & $\begin{array}{l}\text { After } 1 \text { year of } \\
\text { ETN }\end{array}$ & $\begin{array}{l}\text { Palmoplantar } \\
\text { pustular psoriasis }\end{array}$ & $\begin{array}{l}\text { Clinical } \\
\text { Biopsy was } \\
\text { refused }\end{array}$ & $\begin{array}{l}\text { Steroids and vitamin } \\
\text { D derivatives } \\
\text { ETN discontinued }\end{array}$ \\
\hline (120) & Long-standing RA & CZP & Cutaneous & $\begin{array}{l}\text { After } 2^{\text {nd }} \text { infusion } \\
\text { of CZP }\end{array}$ & $\begin{array}{l}\text { Palmoplantar } \\
\text { psoriasis }\end{array}$ & Skin biopsy & $\begin{array}{l}\text { Steroids } \\
\text { CZP discontinued }\end{array}$ \\
\hline (121) & RA & $\begin{array}{l}\text { ADM + } \\
\text { MTX }\end{array}$ & Cutaneous & $\begin{array}{l}\text { After } 4 \text { months of } \\
\text { ADM }\end{array}$ & $\begin{array}{l}\text { Palmoplantar } \\
\text { subcorneal } \\
\text { pustular } \\
\text { dermatosis }\end{array}$ & $\begin{array}{l}\text { Skin biopsy } \\
\text { Histology }\end{array}$ & $\begin{array}{l}\text { Clobetasol } \\
\text { propionate } \\
\text { ADM discontinued }\end{array}$ \\
\hline (122) & Erosive RA & $\begin{array}{l}\text { ADM + } \\
\text { DMARDs }\end{array}$ & Cutaneous & $\begin{array}{l}\text { After } 3 \text { years of } \\
\text { ADM }\end{array}$ & $\begin{array}{l}\text { Intermediate } \\
\text { bullous } \\
\text { pemphigoid and } \\
\text { cicatricial } \\
\text { pemphigoi }\end{array}$ & $\begin{array}{l}\text { Gingival and skin } \\
\text { biopsies }\end{array}$ & $\begin{array}{l}\text { Corticosteroids } \\
\text { ADM discontinued }\end{array}$ \\
\hline$(122)$ & RA & $\mathrm{IFX}+\mathrm{AZA}$ & Cutaneous & $\begin{array}{l}\text { After } 7^{\text {th }} \text { IFX } \\
\text { infusion }\end{array}$ & $\begin{array}{l}\text { Pemphigus } \\
\text { foliaceus }\end{array}$ & $\begin{array}{l}\text { Histology } \\
\text { Serology }\end{array}$ & $\begin{array}{l}\text { Corticosteroids } \\
\text { IFX discontinued }\end{array}$ \\
\hline (123) & $\begin{array}{l}\text { RF-positive } \\
\text { erosive RA and } \\
\text { hepatitis C virus } \\
\text { infection }\end{array}$ & $\begin{array}{l}\mathrm{ADM}+ \\
\mathrm{HQ}\end{array}$ & Cutaneous & $\begin{array}{l}\text { Symptoms after } 22 \\
\text { months of ADM }\end{array}$ & $\begin{array}{l}\text { Granuloma } \\
\text { annulare } \\
\text { Relapse on ETN }\end{array}$ & Skin biopsy & $\begin{array}{l}\text { Prednisone and } \\
\text { fexofenadine } \\
\text { ADM discontinued }\end{array}$ \\
\hline (124) & $\begin{array}{l}\text { AS } \\
\text { Normal baseline } \\
\text { LFT results } \\
\text { Negative baseline } \\
\text { ANA }\end{array}$ & IFX & $\begin{array}{l}\text { Epigastric } \\
\text { discomfort and } \\
\text { jaundice } \\
\text { LFT: bilirubin } 97 \\
\text { pmol/L, ALP } 521 \\
\text { U/L, } \gamma \text {-GTP } 614 \\
\text { U/L, ALT } 621 \\
\text { U/L and AST } 821 \\
\text { U/L }\end{array}$ & $\begin{array}{l}\text { After } 3 \text { months of } \\
\text { IFX }\end{array}$ & $\begin{array}{l}\text { De novo } \\
\text { autoimmune } \\
\text { hepatitis with a } \\
\text { mixed hepatitis } \\
\text { and cholestatic } \\
\text { presentation }\end{array}$ & $\begin{array}{l}\text { CT scan of the } \\
\text { abdomen } \\
\text { Liver biopsy } \\
\text { Autoantibodies } \\
\text { Abnormal LFT } \\
\text { results }\end{array}$ & $\begin{array}{l}\text { Prednisone } \\
\text { IFX discontinued }\end{array}$ \\
\hline$(125)$ & $\begin{array}{l}\text { RA } \\
\text { Asymptomatic } \\
\text { cirrhosis } \\
\text { Normal baseline } \\
\text { LFT results } \\
\text { Negative baseline } \\
\text { ANA }\end{array}$ & IFX & $\begin{array}{l}\text { Scleral icterus } \\
\text { and moderate } \\
\text { jaundice } \\
\text { LFT: ALP } 840 \\
\text { U/L, AST } 1690 \\
\text { U/L, ALT } 2250 \\
\text { U/L, total } \\
\text { bilirubin } 15.14 \\
\text { mg/dL and direct } \\
\text { bilirubin } 12.2 \\
\mathrm{mg} / \mathrm{dL}\end{array}$ & $\begin{array}{l}\text { After } 1 \text { year of } \\
\text { IFX }\end{array}$ & $\begin{array}{l}\text { De novo } \\
\text { autoimmune } \\
\text { hepatitis with } \\
\text { cholestatic } \\
\text { presentation }\end{array}$ & $\begin{array}{l}\text { Liver MRI } \\
\text { Liver biopsy } \\
\text { Autoantibodies } \\
\text { Abnormal LFT } \\
\text { results }\end{array}$ & $\begin{array}{l}\text { Methylprednisolone } \\
\text { IFX discontinued }\end{array}$ \\
\hline (126) & $\begin{array}{l}\text { RA } \\
\text { Negative baseline } \\
\text { ANA }\end{array}$ & $\begin{array}{l}\text { IFX }+ \\
\text { MTX and } \\
\text { prednisolon } \\
\text { e }\end{array}$ & $\begin{array}{l}\text { LFT: ALT } 1061 \\
\text { U/L, AST } 2019 \\
\text { U/L and ALP } 244 \\
\text { U/L }\end{array}$ & $\begin{array}{l}\text { After } 3 \text { years of } \\
\text { IFX }\end{array}$ & $\begin{array}{l}\text { Autoimmune } \\
\text { hepatitis }\end{array}$ & $\begin{array}{l}\text { Liver biopsy } \\
\text { Autoantibodies } \\
\text { Abnormal LFT } \\
\text { results }\end{array}$ & $\begin{array}{l}\text { Prednisolone } \\
\text { IFX discontinued }\end{array}$ \\
\hline
\end{tabular}


Table 3 Cont'd.

\begin{tabular}{|c|c|c|c|c|c|c|c|}
\hline $\begin{array}{l}\text { Refer- } \\
\text { ence }\end{array}$ & $\begin{array}{c}\text { Patient } \\
\text { Conditions }\end{array}$ & Treatment & $\begin{array}{l}\text { Course of } \\
\text { Reaction }\end{array}$ & $\begin{array}{l}\text { Presentation of } \\
\text { Symptoms }\end{array}$ & Diagnosis & $\begin{array}{c}\text { Techniques to } \\
\text { Validate } \\
\text { Diagnosis } \\
\end{array}$ & $\begin{array}{l}\text { Management of } \\
\text { Symptoms }\end{array}$ \\
\hline (127) & $\begin{array}{l}\text { RA } \\
\text { Mild baseline } \\
\text { abnormal LFT } \\
\text { results attributed to } \\
\text { NSAIDs }\end{array}$ & $\begin{array}{l}\text { ETN + } \\
\text { MTX and } \\
\text { NSAIDs }\end{array}$ & $\begin{array}{l}\text { Tender } \\
\text { hepatomegaly } \\
\text { LFL: total } \\
\text { bilirubin } 1.2 \\
\text { mg/dl, direct } \\
\text { bilirubin } 0.6 \\
\text { mg/dL, AST } 237 \\
\text { IU/L, ALT } 300 \\
\text { IU/L, ALP } 488 \\
\text { IU/L and } \gamma \text {-GTP } \\
126 \text { IU/L }\end{array}$ & $\begin{array}{l}\text { After } 2 \text { weeks of } \\
\text { ETN }\end{array}$ & $\begin{array}{l}\text { Acute } \\
\text { exacerbation of } \\
\text { autoimmune } \\
\text { hepatitis }\end{array}$ & $\begin{array}{l}\text { Liver biopsy } \\
\text { Autoantibodies } \\
\text { Abnormal LFT } \\
\text { results }\end{array}$ & $\begin{array}{l}\text { Glucocorticoids } \\
\text { ETN discontinued }\end{array}$ \\
\hline (128) & $\begin{array}{l}\text { RA } \\
\text { Normal baseline } \\
\text { LFT results } \\
\text { Negative baseline } \\
\text { ANA }\end{array}$ & $\mathrm{ADM}$ & $\begin{array}{l}\text { Mild } \\
\text { hepatomegaly } \\
\text { with steatosis } \\
\text { LFT: ALT } 266 \\
\text { UI/L and AST } \\
555 \text { UI/L, normal } \\
\text { bilirubin, ALP } \\
\text { and } \gamma \text {-GTP }\end{array}$ & $\begin{array}{l}\text { After } 5^{\text {th }} \text { infusion } \\
\text { of ADM }\end{array}$ & $\begin{array}{l}\text { Autoimmune } \\
\text { hepatitis }\end{array}$ & $\begin{array}{l}\text { Liver biopsy } \\
\text { Autoantibodies } \\
\text { Abnormal LFT } \\
\text { results }\end{array}$ & $\begin{array}{l}\text { Prednisone } \\
\text { ADM discontinued }\end{array}$ \\
\hline (129) & Erosive RA & ETN & Neurological & $\begin{array}{l}\text { After } 37 \text { months o } \\
\text { ETN }\end{array}$ & $\begin{array}{l}\text { Antiphospho- } \\
\text { lipid syndrome/ } \\
\text { central nervous } \\
\text { system lupus }\end{array}$ & $\begin{array}{l}\text { Cranial MRI } \\
\text { Autoantibodies }\end{array}$ & $\begin{array}{l}\text { Corticosteroids, } \\
\text { warfarin and } \\
\text { azathioprine } \\
\text { ETN discontinued }\end{array}$ \\
\hline (130) & $\begin{array}{l}\text { Spondylo- } \\
\text { arthropathy }\end{array}$ & $\begin{array}{l}\text { ADM + } \\
\text { MTX }\end{array}$ & $\begin{array}{l}\text { Gastrointestinal, } \\
\text { leukocytosis and } \\
\text { neutrophilia }\end{array}$ & $\begin{array}{l}\text { After } 3^{\text {rd }} \text { infusion } \\
\text { of ADM }\end{array}$ & $\begin{array}{l}\text { Antiphospho- } \\
\text { lipid syndrome }\end{array}$ & Autoantibodies & $\begin{array}{l}\text { Heparin, tinzaparin, } \\
\text { clopidogrel and } \\
\text { steroids } \\
\text { ADM discontinued }\end{array}$ \\
\hline
\end{tabular}

Table 4. Neurological adverse events

\begin{tabular}{|c|c|c|c|c|c|c|c|}
\hline $\begin{array}{c}\text { Refer- } \\
\text { ence }\end{array}$ & $\begin{array}{c}\text { Patient } \\
\text { Character- } \\
\text { istics } \\
\end{array}$ & $\begin{array}{c}\text { Treatment } \\
\text { for } \\
\text { Conditions } \\
\end{array}$ & $\begin{array}{l}\text { Course of } \\
\text { Reaction }\end{array}$ & $\begin{array}{l}\text { Presentation } \\
\text { of Symptoms }\end{array}$ & Diagnosis & $\begin{array}{c}\text { Technique to } \\
\text { Validate } \\
\text { Diagnosis } \\
\end{array}$ & $\begin{array}{l}\text { Treatment for } \\
\text { Symptoms }\end{array}$ \\
\hline$(135)$ & AS & ETN & $\begin{array}{l}\text { Paresthesia and } \\
\text { urinary } \\
\text { incontinence }\end{array}$ & $\begin{array}{l}\text { After } 30 \\
\text { months of ETN }\end{array}$ & Demyelinating disease & $\begin{array}{l}\text { Neurological } \\
\text { examination } \\
\text { Brain MRI }\end{array}$ & ETN discontinued \\
\hline$(136)$ & $\begin{array}{l}\text { AS and acute } \\
\text { anterior HLA- } \\
\text { B27-positive } \\
\text { uveitis }\end{array}$ & IFX & $\begin{array}{l}\text { Blurred vision } \\
\text { scotoma } \\
\text { Myopic } \\
\text { chorioretinal } \\
\text { atrophy }\end{array}$ & $\begin{array}{l}\text { and After } 10 \\
\text { months of IFX }\end{array}$ & $\begin{array}{l}\text { Occipital } \\
\text { demyelination }\end{array}$ & Brain MRI & IFX discontinued \\
\hline$\overline{(137)}$ & $\mathrm{AS}+$ psoriasis & SIFX & Paresthesia & $\begin{array}{l}\text { After } 4 \text { years of } \\
\text { ETN, ADM } \\
\text { and IFX }\end{array}$ & $\begin{array}{l}\text { Multifocal sensory } \\
\text { motor demyelinating } \\
\text { neuropathy with } \\
\text { conduction block }\end{array}$ & $\begin{array}{l}\text { CSF analysis } \\
\text { Electromyography } \\
\text { Nerve biopsy }\end{array}$ & $\begin{array}{l}\text { Intravenous } \\
\text { immunoglobulin } \\
\text { IFX discontinued }\end{array}$ \\
\hline
\end{tabular}


Table 4 Cont'd.

\begin{tabular}{|c|c|c|c|c|c|c|c|}
\hline $\begin{array}{c}\text { Refer- } \\
\text { ence }\end{array}$ & $\begin{array}{l}\text { Patient } \\
\text { Charac- } \\
\text { teristics }\end{array}$ & $\begin{array}{c}\text { Treatment } \\
\text { for } \\
\text { Conditions }\end{array}$ & $\begin{array}{l}\text { Course of } \\
\text { Reaction }\end{array}$ & $\begin{array}{l}\text { Presentation } \\
\text { of Symptoms }\end{array}$ & Diagnosis & $\begin{array}{c}\text { Technique to } \\
\text { Validate } \\
\text { Diagnosis } \\
\end{array}$ & $\begin{array}{l}\text { Treatment for } \\
\text { Symptoms }\end{array}$ \\
\hline (137) & $\begin{array}{l}\text { AS + Crohn's } \\
\text { disease }\end{array}$ & IFX & $\begin{array}{l}\text { Sensory motor } \\
\text { deficit }\end{array}$ & $\begin{array}{l}\text { After } 6 \text { months } \\
\text { of IFX }\end{array}$ & $\begin{array}{l}\text { Multifocal sensory } \\
\text { motor demyelinating } \\
\text { neuropathy with } \\
\text { conduction block }\end{array}$ & $\begin{array}{l}\text { CSF analysis } \\
\text { Electromyography } \\
\text { Nerve biopsy }\end{array}$ & $\begin{array}{l}\text { Intravenous } \\
\text { immunoglobulin } \\
\text { ETN discontinued }\end{array}$ \\
\hline (137) & RA & $\mathrm{ADM}$ & $\begin{array}{l}\text { Tingling and } \\
\text { burning sensations }\end{array}$ & $\begin{array}{l}\text { After } 2 \text { years of } \\
\text { ADM }\end{array}$ & $\begin{array}{l}\text { f Multifocal sensory } \\
\text { demyelinating } \\
\text { neuropathy }\end{array}$ & $\begin{array}{l}\text { CSF analysis } \\
\text { Electromyography } \\
\text { Nerve biopsy } \\
\end{array}$ & $\begin{array}{l}\text { No treatment } \\
\text { ADM dose reduced }\end{array}$ \\
\hline$(138)$ & $\begin{array}{l}\text { HLA-B27- } \\
\text { negative AS }\end{array}$ & $\mathrm{ADM}$ & $\begin{array}{l}\text { Reduced hearing } \\
\text { acuity and urinary } \\
\text { incontinence }\end{array}$ & $\begin{array}{l}\text { After } 3 \text { years of } \\
\text { ADM }\end{array}$ & $\begin{array}{l}\text { fCNS demyelination } \\
\text { evolving to multiple } \\
\text { sclerosis }\end{array}$ & $\begin{array}{l}\text { CSF analysis } \\
\text { Brain MRI }\end{array}$ & $\begin{array}{l}\text { Intravenous } \\
\text { methylprednisolone } \\
\text { ADM discontinued }\end{array}$ \\
\hline (138) & AS & ETN & $\begin{array}{l}\text { Ptosis and } \\
\text { peripheral paresis }\end{array}$ & $\begin{array}{l}\text { After } 6 \text { years of } \\
\text { ETN }\end{array}$ & $\begin{array}{l}\text { fCNS demyelination } \\
\text { evolving to multiple } \\
\text { sclerosis }\end{array}$ & $\begin{array}{l}\text { CSF analysis } \\
\text { Brain MRI } \\
\text { Cervical MRI }\end{array}$ & $\begin{array}{l}\text { Intravenous } \\
\text { methylprednisolone } \\
\text { ETN discontinued }\end{array}$ \\
\hline (140) & RA & ETN & $\begin{array}{l}\text { Pain, swelling, loss } \\
\text { of balance, muscle } \\
\text { weakness and } \\
\text { ataxia } \\
\text { Loss of sensory } \\
\text { perception }\end{array}$ & $\begin{array}{l}\text { After } 2^{\text {nd }} \\
\text { infusion of } \\
\text { ETN }\end{array}$ & $\begin{array}{l}\text { Chronic inflammatory } \\
\text { demyelinating } \\
\text { polyneuropathy }\end{array}$ & $\begin{array}{l}\text { CSF analysis } \\
\text { Electrodiagnostic } \\
\text { findings }\end{array}$ & $\begin{array}{l}\text { Intravenous } \\
\text { immunoglobulin } \\
\text { ETN discontinued }\end{array}$ \\
\hline$(140)$ & RA & $\begin{array}{l}\text { IFX + MTX, } \\
\text { HQ and } \\
\text { prednisone }\end{array}$ & Numbness & $\begin{array}{l}\text { After } 1 \text { year of } \\
\text { IFX }\end{array}$ & $\begin{array}{l}\text { Chronic inflammatory } \\
\text { demyelinating } \\
\text { polyneuropathy }\end{array}$ & $\begin{array}{l}\text { Electrodiagnostic } \\
\text { findings }\end{array}$ & $\begin{array}{l}\text { Intravenous } \\
\text { immunoglobulin } \\
\text { IFX discontinued }\end{array}$ \\
\hline$(141)$ & RA & $\mathrm{ADM}$ & $\begin{array}{l}\text { Progressive } \\
\text { weakness }\end{array}$ & $\begin{array}{l}\text { After } 8 \text { months } \\
\text { of ADM }\end{array}$ & $\begin{array}{l}\text { Immune-mediated } \\
\text { monofocal motor } \\
\text { neuropathy }\end{array}$ & $\begin{array}{l}\text { Clinical } \\
\text { Arm MRI }\end{array}$ & $\begin{array}{l}\text { Endovenous } \\
\text { immunoglobulin } \\
\text { ADM discontinued } \\
\end{array}$ \\
\hline (142) & RA & $\mathrm{ADM}$ & $\begin{array}{l}\text { Numbness, } \\
\text { weakness and } \\
\text { decreased reflexes }\end{array}$ & $\begin{array}{l}\text { After } 2.5 \text { years } \\
\text { of ADM }\end{array}$ & $\begin{array}{l}\text { Chronic inflammatory } \\
\text { axonal polyradiculo- } \\
\text { neuropathy }\end{array}$ & $\begin{array}{l}\text { CSF analysis } \\
\text { Spinal MRI }\end{array}$ & $\begin{array}{l}\text { Intravenous } \\
\text { immunoglobulin, } \\
\text { azathioprine and } \\
\text { prednisone } \\
\text { ADM discontinued }\end{array}$ \\
\hline (143) & RA & $\begin{array}{l}\text { ADM + } \\
\text { MTX }\end{array}$ & $\begin{array}{l}\text { Tetraparesis, facial } \\
\text { paralysis, } \\
\text { ophthalmoparesis } \\
\text { and respiratory } \\
\text { failure }\end{array}$ & $\begin{array}{l}\text { After } 14 \\
\text { months of } \\
\text { ADM }\end{array}$ & $\begin{array}{l}\text { Guillain-Barré } \\
\text { syndrome with acute } \\
\text { motor axonal } \\
\text { neuropathy }\end{array}$ & $\begin{array}{l}\text { CSF analysis } \\
\text { Neurophysiologica } \\
1 \text { examination }\end{array}$ & $\begin{array}{l}\text { Intravenous immune- } \\
\text { globulins } \\
\text { ADM and MTX } \\
\text { discontinued }\end{array}$ \\
\hline$(142)$ & $\begin{array}{l}\text { AS and } \\
\text { Grave's } \\
\text { disease }\end{array}$ & IFX & $\begin{array}{l}\text { Leg weakness and } \\
\text { paraparesis }\end{array}$ & $\begin{array}{l}\text { After } 1.5 \text { years } \\
\text { of IFX }\end{array}$ & $\begin{array}{l}\text { Longitudinally } \\
\text { extensive transverse } \\
\text { myelitis }\end{array}$ & $\begin{array}{l}\text { Neurological exam } \\
\text { Nerve conduction } \\
\text { study and } \\
\text { electromyography } \\
\text { Brain and spinal } \\
\text { MRI }\end{array}$ & $\begin{array}{l}\text { Intravenous } \\
\text { methylprednisolone } \\
\text { IFX discontinued }\end{array}$ \\
\hline
\end{tabular}


Table 4 Cont'd.

\begin{tabular}{|c|c|c|c|c|c|c|c|}
\hline $\begin{array}{c}\text { Refer- } \\
\text { ence }\end{array}$ & $\begin{array}{l}\text { Patient } \\
\text { Charac- } \\
\text { teristics }\end{array}$ & $\begin{array}{c}\text { Treatment } \\
\text { for } \\
\text { Conditions } \\
\end{array}$ & $\begin{array}{l}\text { Course of } \\
\text { Reaction }\end{array}$ & $\begin{array}{l}\text { Presentation } \\
\text { of Symptoms }\end{array}$ & Diagnosis & $\begin{array}{c}\text { Technique to } \\
\text { Validate } \\
\text { Diagnosis } \\
\end{array}$ & $\begin{array}{l}\text { Treatment for } \\
\text { Symptoms }\end{array}$ \\
\hline$(144)$ & RA & ETN & $\begin{array}{l}\text { Paresthesia and } \\
\text { bowel incontinence }\end{array}$ & $\begin{array}{l}\text { After } 42 \\
\text { months of ETN }\end{array}$ & Cervical myelitis & Spinal MRI & $\begin{array}{l}\text { Folate supplements and } \\
\text { methylprednisolone } \\
\text { ETN discontinued }\end{array}$ \\
\hline$(145)$ & $\begin{array}{l}\text { RF-positive } \\
\text { RA }\end{array}$ & $\mathrm{ADM}$ & $\begin{array}{l}\text { Pain and } \\
\text { parasthesias }\end{array}$ & $\begin{array}{l}\text { After } 4 \text { weeks } \\
\text { of ADM }\end{array}$ & $\begin{array}{l}\text { Mononeuritis } \\
\text { multiplex }\end{array}$ & $\begin{array}{l}\text { Electromyography } \\
\text { Sural nerve biopsy }\end{array}$ & $\begin{array}{l}\text { Methylprednisolone and } \\
\text { cyclosporine } \\
\text { ADM discontinued }\end{array}$ \\
\hline$(146)$ & $\begin{array}{l}\text { RA and } \\
\text { osteoporosis }\end{array}$ & IFX & Amaurosis & $\begin{array}{l}\text { Symptoms } \\
\text { after } 4^{\text {th }} \\
\text { infusion of IFX } \\
\end{array}$ & Optic neuritis & MRI of the orbits & $\begin{array}{l}\text { Methylprednisolone } \\
\text { IFX discontinued }\end{array}$ \\
\hline$\overline{(147)}$ & $\begin{array}{l}\text { HLA-B27- } \\
\text { positive AS }\end{array}$ & ETN & $\begin{array}{l}\text { Aphasia and } \\
\text { hemiparesis } \\
\text { Generalized } \\
\text { seizures }\end{array}$ & $\begin{array}{l}\text { After } 11 \\
\text { months of ETN }\end{array}$ & $\begin{array}{l}\text { Tumefactive } \\
\text { demyelinating lesions }\end{array}$ & $\begin{array}{l}\text { CSF analysis } \\
\text { Brain MRI } \\
\text { Brain biopsy }\end{array}$ & $\begin{array}{l}\text { Intravenous } \\
\text { methylprednisolone } \\
\text { ETN discontinued }\end{array}$ \\
\hline$\overline{(148)}$ & $\begin{array}{l}\text { RF-negative } \\
\text { pediatric } \\
\text { systemic } \\
\text { idiopathic } \\
\text { arthritis } \\
\end{array}$ & ETN & $\begin{array}{l}\text { Generalized } \\
\text { seizures and } \\
\text { sustained clonus }\end{array}$ & $\begin{array}{l}\text { After } 3^{\text {rd }} \\
\text { infusion of } \\
\text { ETN }\end{array}$ & Encephalopathy & $\begin{array}{l}\text { CSF analysis } \\
\text { Electroencephalogr } \\
\text { am } \\
\text { Brain MRI }\end{array}$ & $\begin{array}{l}\text { No treatment } \\
\text { ETN discontinued }\end{array}$ \\
\hline$(149)$ & $\begin{array}{l}\text { RF-positive } \\
\text { erosive RA }\end{array}$ & $\begin{array}{l}\text { IFX + MTX, } \\
\text { HQ and } \\
\text { prednisone }\end{array}$ & $\begin{array}{l}\text { Generalized tonic- } \\
\text { clonic seizures, } \\
\text { coma and orofacial } \\
\text { myoclonus }\end{array}$ & $\begin{array}{l}\text { After } 3 \text { years of } \\
\text { IFX }\end{array}$ & f Global encephalopathy & $\begin{array}{l}\text { Brain MRI } \\
\text { Electroencephalogr } \\
\text { am }\end{array}$ & $\begin{array}{l}\text { Pulse } \\
\text { methylprednisolone } \\
\text { IFX discontinued }\end{array}$ \\
\hline$(156)$ & $\begin{array}{l}\text { Erosive } \\
\text { polyarthritis } \\
\text { and systemic } \\
\text { lupus } \\
\text { erythematosus }\end{array}$ & $\begin{array}{l}\text { ETN and } \\
\text { prednisone }\end{array}$ & $\begin{array}{l}\text { Hemiparesis and } \\
\text { hemiataxia } \\
\text { Facial numbness } \\
\text { and dysarthria }\end{array}$ & $\begin{array}{l}\text { After } 4 \text { years of } \\
\text { ETN }\end{array}$ & $\begin{array}{l}\text { f Progressive multifocal } \\
\text { leukoencephalopathy } \\
\text { with positive JCV }\end{array}$ & $\begin{array}{l}\text { CSF analysis } \\
\text { Brain MRI } \\
\text { Neurological } \\
\text { examination } \\
\text { Serological } \\
\text { evaluation } \\
\end{array}$ & $\begin{array}{l}\text { No treatment } \\
\text { ETN discontinued }\end{array}$ \\
\hline$(129)$ & RA & ETN & $\begin{array}{l}\text { Neurological } \\
\text { illness }\end{array}$ & $\begin{array}{l}\text { After } 1 \text { month } \\
\text { of ETN }\end{array}$ & $\begin{array}{l}\text { Epstein-Barr } \\
\text { virus encephalitis }\end{array}$ & $\begin{array}{l}\text { CSF analysis } \\
\text { Brain MRI } \\
\text { Polymerase chain } \\
\text { reaction }\end{array}$ & $\begin{array}{l}\text { Valganciclovir } \\
\text { ETN discontinued }\end{array}$ \\
\hline
\end{tabular}


Table 5. Hematological adverse events

\begin{tabular}{|c|c|c|c|c|c|c|c|}
\hline $\begin{array}{c}\text { Refer- } \\
\text { ence }\end{array}$ & $\begin{array}{l}\text { Patient } \\
\text { Charac- } \\
\text { teristics }\end{array}$ & $\begin{array}{c}\text { Treatment } \\
\text { for } \\
\text { Conditions } \\
\end{array}$ & Course of Reaction & $\begin{array}{c}\text { Presentatio } \\
\text { n of } \\
\text { Symptoms }\end{array}$ & Diagnosis & $\begin{array}{c}\text { Technique to } \\
\text { Validate Diagnosis }\end{array}$ & $\begin{array}{l}\text { Treatment } \\
\text { for } \\
\text { Symptoms }\end{array}$ \\
\hline$(159)$ & RA & $\begin{array}{l}\text { ETN }+ \\
\text { MTX and } \\
\text { predni- } \\
\text { solone }\end{array}$ & Asymptomatic & $\begin{array}{l}\text { After } 7 \text { th } \\
\text { ETN } \\
\text { injection }\end{array}$ & Neutropenia $(0.84 \times 109 / \mathrm{L})$ & $\begin{array}{l}\text { Bone marrow } \\
\text { examination } \\
\text { Laboratory evaluation }\end{array}$ & $\begin{array}{l}\text { Increase } \\
\text { prednisolone } \\
\text { dose } \\
\text { ETN } \\
\text { discontinued }\end{array}$ \\
\hline$\overline{(160)}$ & RA & $\begin{array}{l}\text { ADM + } \\
\text { MTX and } \\
\text { prednisone }\end{array}$ & Asymptomatic & $\begin{array}{l}\text { After 1st } \\
\text { ADM } \\
\text { injection }\end{array}$ & $\begin{array}{l}\text { Neutropenia (lowest } \\
0.90 \times 109 / \mathrm{L})\end{array}$ & Laboratory evaluation & $\begin{array}{l}\text { No treatment } \\
\text { ADM } \\
\text { discontinued }\end{array}$ \\
\hline$(161)$ & RA & $\begin{array}{l}\mathrm{ETN}+ \\
\text { prednisolon } \\
\mathrm{e}\end{array}$ & Gingival abscess & $\begin{array}{l}\text { After } 1 \\
\text { month of } \\
\text { ETN }\end{array}$ & $\begin{array}{l}\text { Severe neutropenia (total } \\
\text { leukocyte count } 1.25 \times 109 / \mathrm{L} \\
\text { and the absolute neutrophil } \\
\text { count } 0.15 \times 109 / \mathrm{L} \text { ) }\end{array}$ & $\begin{array}{l}\text { Bone marrow } \\
\text { examination } \\
\text { Cytogenetic analysis } \\
\text { Laboratory evaluation }\end{array}$ & $\begin{array}{l}\text { Granulocyte } \\
\text { stimulating } \\
\text { factor } \\
\text { ETN } \\
\text { discontinued }\end{array}$ \\
\hline$(163)$ & RA & $\begin{array}{l}\text { ETN + } \\
\text { MTX and } \\
\text { leflunomide }\end{array}$ & Petechia & $\begin{array}{l}\text { After } 3 \\
\text { months of } \\
\text { ETN }\end{array}$ & $\begin{array}{l}\text { Leukopenia (white blood cells } \\
2.4 \times 109 / \mathrm{L} \text { vs. } 5.9 \times 109 / \mathrm{L} \text { at } \\
\text { baseline) } \\
\text { Thrombocytopenia (platelet } \\
\text { count } 60 \times 109 / \mathrm{L} \text { vs. } \\
187 \times 109 / \mathrm{L} \text { at baseline) }\end{array}$ & Laborator & $\begin{array}{l}\text { ETN } \\
\text { discontinued }\end{array}$ \\
\hline$(164)$ & RA & ETN & Asymptomatic & $\begin{array}{l}\text { After 3rd } \\
\text { ETN } \\
\text { injection }\end{array}$ & $\begin{array}{l}\text { Thrombocytopenia (platelet } \\
\text { count } 38 \times 109 / \mathrm{L} \text { ) }\end{array}$ & Laboratory evaluation & $\begin{array}{l}\text { No treatment } \\
\text { ETN } \\
\text { discontinued }\end{array}$ \\
\hline$(168)$ & RA & $\begin{array}{l}\text { ETN + } \\
\text { MTX }\end{array}$ & $\begin{array}{l}\text { Fever (38.5-C), buccal } \\
\text { ulcerations and } \\
\text { pancytopenia }\end{array}$ & $\begin{array}{l}\text { After } 3 \\
\text { weeks of } \\
\text { ETN }\end{array}$ & $\begin{array}{l}\text { Pancytopenia (white blood } \\
\text { cells } 2.88 \times 109 / \mathrm{L} \text {, absolute } \\
\text { neutrophils } 1.09 \times 109 / \mathrm{L}, \\
\text { platelets } 30 \times 109 / \mathrm{L} \text { ) }\end{array}$ & & $\begin{array}{l}\text { Acyclovir and } \\
\text { ciprofloxacin } \\
\text { ETN and } \\
\text { MTX } \\
\text { discontinued }\end{array}$ \\
\hline (169) & RA & $\begin{array}{l}\text { ETN + } \\
\text { MTX and } \\
\text { prednisone }\end{array}$ & $\begin{array}{l}\text { Severe multilobar } \\
\text { pneumonia }\end{array}$ & $\begin{array}{l}\text { After } 1 \text { year } \\
\text { of ETN }\end{array}$ & $\begin{array}{l}\text { Severe pancytopenia (platelets } \\
122 \times 109 / \mathrm{L} \text {, erythrocytes } \\
2.81 \times 1012 / \mathrm{L} \text {, hematocrit } \\
26.2 \% \text {, hemoglobin } 8.4 \mathrm{~g} / \mathrm{dL} \text {, } \\
\text { neutrophils } 0.95 \times 109 / \mathrm{L}, \\
\text { lymphocytes } 0.29 \times 109 / \mathrm{L} \text { and } \\
\text { leukocytes } 1.41 \times 109 / \mathrm{L} \text { ) }\end{array}$ & Laboratory evaluation & $\begin{array}{l}\text { Piperacillin- } \\
\text { tazobactam } \\
\text { and targocid } \\
\text { ETN } \\
\text { discontinued }\end{array}$ \\
\hline$\overline{(170)}$ & $\begin{array}{l}\text { RF- } \\
\text { positive } \\
\text { RA }\end{array}$ & $\begin{array}{l}\text { ETN }+ \\
\text { MTX and } \\
\text { predni- } \\
\text { solone }\end{array}$ & $\begin{array}{l}\text { Cutaneous, disseminated } \\
\text { intravascular coagulation, } \\
\text { respiratory failure, } \\
\text { leukocytoclastic vasculitis, } \\
\text { pancytopenia with white } \\
\text { blood cell count } 2000 / \mu \mathrm{L} \text {, } \\
\text { hemoglobin } 8.5 \mathrm{~g} / \mathrm{dL}, \\
\text { platelet count } 84000 / \mu \mathrm{L}\end{array}$ & $\begin{array}{l}\text { After } 3 \text { years } \\
\text { of ETN }\end{array}$ & $\begin{array}{l}\text { Drug-induced lupus } \\
\text { accompanied by } \\
\text { hemophagocytic syndrome }\end{array}$ & $\begin{array}{l}\text { Laboratory evaluation } \\
\text { Skin biopsy } \\
\text { Bone marrow biopsy } \\
\text { Chest and abdomen } \\
\text { CT scan } \\
\text { Cytokine profile } \\
\text { analysis } \\
\text { Autoantibodies }\end{array}$ & $\begin{array}{l}\text { IV } \\
\text { methylprednis } \\
\text { olone }\end{array}$ \\
\hline
\end{tabular}


Table 6. Adverse events in other organs

\begin{tabular}{|c|c|c|c|c|c|c|c|}
\hline $\begin{array}{l}\text { Refer- } \\
\text { ence }\end{array}$ & $\begin{array}{l}\text { Patient } \\
\text { Charac- } \\
\text { teristics } \\
\end{array}$ & $\begin{array}{l}\text { Treatment } \\
\text { for } \\
\text { Conditions } \\
\end{array}$ & Course of Reaction & $\begin{array}{c}\text { Presenta- } \\
\text { tion of } \\
\text { Symptoms } \\
\end{array}$ & Diagnosis & $\begin{array}{c}\text { Technique to Validate } \\
\text { Diagnosis }\end{array}$ & $\begin{array}{l}\text { Treatment for } \\
\text { Symptoms }\end{array}$ \\
\hline (177) & $\begin{array}{l}\text { RF- } \\
\text { positive } \\
\text { anti-CCP- } \\
\text { positive } \\
\text { RA }\end{array}$ & $\mathrm{CZP}+\mathrm{MTX}$ & $\begin{array}{l}\text { Dyspnea and cough } \\
\text { Inspiratory crepitations, } \\
\text { ground-glass opacities } \\
\text { Respiratory function } \\
\text { impairment }\end{array}$ & $\begin{array}{l}\text { After } 8 \\
\text { weeks of } \\
\text { CZP }\end{array}$ & Non-infectious ILD & $\begin{array}{l}\text { High-resolution CT } \\
\text { scan } \\
\text { Bronchoscopy }\end{array}$ & $\begin{array}{l}\text { Methylpredni- } \\
\text { solone } \\
\text { CZP } \\
\text { discontinued }\end{array}$ \\
\hline$(178)$ & $\begin{array}{l}\text { Erosive } \\
\text { RA }\end{array}$ & $\mathrm{CZP}+\mathrm{MTX}$ & $\begin{array}{l}\text { Dyspnea and cough } \\
\text { Basal crackles, ground- } \\
\text { glass opacities } \\
\text { Respiratory function } \\
\text { impairment }\end{array}$ & $\begin{array}{l}\text { After } 4 \\
\text { months of } \\
\text { CZP }\end{array}$ & $\begin{array}{l}\text { Non-infectious ILD } \\
\text { with features of } \\
\text { organizing pneumonia }\end{array}$ & $\begin{array}{l}\text { Chest CT } \\
\text { Lung biopsy }\end{array}$ & $\begin{array}{l}\text { Methylpredni- } \\
\text { solone } \\
\text { CZP } \\
\text { discontinued }\end{array}$ \\
\hline$(179)$ & RA & $\begin{array}{l}\mathrm{ADM}+ \\
\mathrm{MTX}\end{array}$ & $\begin{array}{l}\text { Dyspnea and cough } \\
\text { Ground-glass opacities }\end{array}$ & $\begin{array}{l}\text { After } 2 \mathrm{nd} \\
\text { dose of } \\
\text { ADM }\end{array}$ & Acute ILD & $\begin{array}{l}\text { High-resolution CT } \\
\text { scan }\end{array}$ & $\begin{array}{l}\text { Prednisone } \\
\text { ADM } \\
\text { discontinued }\end{array}$ \\
\hline$(181)$ & $\begin{array}{l}\text { RF- } \\
\text { positive } \\
\text { RA }\end{array}$ & $\begin{array}{l}\mathrm{CZP}+ \\
\text { leflunomide } \\
\text { and } \\
\text { prednisone }\end{array}$ & $\begin{array}{l}\text { Dyspnea and cough } \\
\text { Severe interstitial lung } \\
\text { fibrosis } \\
\text { Pulmonary eosinophilia }\end{array}$ & $\begin{array}{l}\text { After } 3 \\
\text { months of } \\
\text { CZP }\end{array}$ & Fibrosing alveolitis & Chest X-ray & $\begin{array}{l}\text { Methylpredni- } \\
\text { solone } \\
\text { CZP } \\
\text { discontinued } \\
\text { Died of respira- } \\
\text { tory failure }\end{array}$ \\
\hline$(182)$ & AS & $\begin{array}{l}\text { IFX }+ \\
\text { piroxicam }\end{array}$ & $\begin{array}{l}\text { Dyspnea and cough } \\
\text { Hemoptysis }\end{array}$ & $\begin{array}{l}\text { After } 2 \mathrm{nd} \\
\text { dose of IFX }\end{array}$ & $\begin{array}{l}\text { Diffuse alveolar } \\
\text { hemorrhage }\end{array}$ & $\begin{array}{l}\text { CT scan } \\
\text { Fiberoptic } \\
\text { bronchoscopy }\end{array}$ & $\begin{array}{l}\text { No treatment } \\
\text { IFX discontinued }\end{array}$ \\
\hline$(183)$ & $\begin{array}{l}\text { RA and } \\
\text { psoriatic } \\
\text { arthritis }\end{array}$ & ETN & $\begin{array}{l}\text { Dyspnea and cough } \\
\text { Severe tachypnea and } \\
\text { fine rales }\end{array}$ & $\begin{array}{l}\text { After } 1 \\
\text { month of } \\
\text { ETN }\end{array}$ & $\begin{array}{l}\text { Diffuse alveolar } \\
\text { hemorrhage and severe } \\
\text { acute respiratory } \\
\text { distress syndrome }\end{array}$ & $\begin{array}{l}\text { Chest CT scan } \\
\text { Bronchoalveolar lavage } \\
\text { Lung biopsy } \\
\text { Tracheotomy }\end{array}$ & $\begin{array}{l}\text { Steroids } \\
\text { ETN } \\
\text { discontinued }\end{array}$ \\
\hline (184) & RA & $\mathrm{IFX}+\mathrm{AZA}$ & Dyspnea and cough & $\begin{array}{l}\text { After } 2 \mathrm{nd} \\
\text { dose of IFX }\end{array}$ & Interstitial pneumonitis & $\begin{array}{l}\text { Chest x-rays } \\
\text { High-resolution CT } \\
\text { scan } \\
\text { Transbronchial biopsy }\end{array}$ & $\begin{array}{l}\text { Methylpredni- } \\
\text { solone } \\
\text { IFX discontinued }\end{array}$ \\
\hline$(185)$ & RA & $\begin{array}{l}\mathrm{ADM}+ \\
\text { prednisolone }\end{array}$ & $\begin{array}{l}\text { Cough } \\
\text { Rales, ground-glass } \\
\text { opacities }\end{array}$ & $\begin{array}{l}\text { After } 5 \\
\text { months of } \\
\text { ADM }\end{array}$ & Interstitial pneumonia & $\begin{array}{l}\text { Chest x-rays } \\
\text { High-resolution CT } \\
\text { scan }\end{array}$ & $\begin{array}{l}\text { Prednisolone } \\
\text { ADM } \\
\text { discontinued }\end{array}$ \\
\hline$(186)$ & RA & $\begin{array}{l}\text { ADM + } \\
\text { NSAIDs and } \\
\text { DMARDs }\end{array}$ & $\begin{array}{l}\text { Cough } \\
\text { Fine crackles, , ground- } \\
\text { glass opacities }\end{array}$ & $\begin{array}{l}\text { After } 1 \\
\text { month of } \\
\text { ADM }\end{array}$ & Interstitial pneumonia & $\begin{array}{l}\text { High-resolution CT } \\
\text { scan }\end{array}$ & $\begin{array}{l}\text { Methylpredni- } \\
\text { solone } \\
\text { ADM } \\
\text { discontinued } \\
\end{array}$ \\
\hline (187) & $\begin{array}{l}\text { RA and } \\
\text { history of } \\
\text { ILD }\end{array}$ & $\begin{array}{l}\text { ETN }+ \\
\text { prednisolone }\end{array}$ & $\begin{array}{l}\text { Cough } \\
\text { Fine crackles, ground- } \\
\text { glass opacities }\end{array}$ & $\begin{array}{l}\text { After } 2 \\
\text { months of } \\
\text { ETN }\end{array}$ & $\begin{array}{l}\text { Interstitial pneumonia } \\
\text { with fatal respiratory } \\
\text { failure }\end{array}$ & CT scan & $\begin{array}{l}\text { Steroids } \\
\text { ETN } \\
\text { discontinued }\end{array}$ \\
\hline 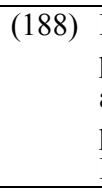 & $\begin{array}{l}\text { RF- } \\
\text { positive } \\
\text { anti-CCP- } \\
\text { positive } \\
\text { RA } \\
\end{array}$ & $\begin{array}{l}\text { ADM } \\
\text { without } \\
\text { DMARDs }\end{array}$ & Dyspnea and cough & $\begin{array}{l}\text { After } 42 \\
\text { months of } \\
\text { ADM }\end{array}$ & Acute pneumonitis & $\begin{array}{l}\text { High-resolution } \\
\text { CT scan } \\
\text { Pulmonary function } \\
\text { tests } \\
\text { Lung biopsy } \\
\end{array}$ & $\begin{array}{l}\text { Corticosteroids } \\
\text { ADM } \\
\text { discontinued }\end{array}$ \\
\hline (189) & RA & $\mathrm{CZP}+\mathrm{MTX}$ & $\begin{array}{l}\text { Dyspnea and cough } \\
\text { Ground-glass opacities } \\
\text { Acute respiratory } \\
\text { distress }\end{array}$ & $\begin{array}{l}\text { After 4th } \\
\text { dose of IFX }\end{array}$ & $\begin{array}{l}\text { Severe acute } \\
\text { pneumonitis }\end{array}$ & $\begin{array}{l}\text { Positron emission } \\
\text { tomography/CT scan } \\
\text { High-resolution } \\
\text { CT scan }\end{array}$ & $\begin{array}{l}\text { Prednisolone } \\
\text { CZP } \\
\text { discontinued }\end{array}$ \\
\hline$(190)$ & RA & $\begin{array}{l}\text { ETN mono- } \\
\text { therapy }\end{array}$ & $\begin{array}{l}\text { Dyspnea and cough } \\
\text { Transient skin rash, } \\
\text { leukopenia }\end{array}$ & $\begin{array}{l}\text { After } 16 \\
\text { months of } \\
\text { ETN }\end{array}$ & $\begin{array}{l}\text { Organizing pneumonia } \\
\text { with concomitant } \\
\text { lupus }\end{array}$ & $\begin{array}{l}\text { Chest radiography } \\
\text { High-resolution } \\
\text { CT scan } \\
\text { Thoracoscopic lung } \\
\text { biopsy } \\
\text { Autoantibodies }\end{array}$ & $\begin{array}{l}\text { Prednisolone } \\
\text { ETN } \\
\text { discontinued }\end{array}$ \\
\hline
\end{tabular}


Table 6 Cont'd.

\begin{tabular}{|c|c|c|c|c|c|c|c|}
\hline $\begin{array}{l}\text { Refer- } \\
\text { ence }\end{array}$ & $\begin{array}{l}\text { Patient } \\
\text { Charac- } \\
\text { teristics }\end{array}$ & $\begin{array}{l}\text { Treatment } \\
\text { for } \\
\text { Conditions } \\
\end{array}$ & Course of Reaction & $\begin{array}{c}\text { Presenta- } \\
\text { tion of } \\
\text { Symptoms } \\
\end{array}$ & Diagnosis & $\begin{array}{c}\text { Technique to Validate } \\
\text { Diagnosis }\end{array}$ & $\begin{array}{l}\text { Treatment for } \\
\text { Symptoms }\end{array}$ \\
\hline (196) & $\begin{array}{l}\text { RF- } \\
\text { positive } \\
\text { RA }\end{array}$ & $\begin{array}{l}\text { IFX }+ \\
\text { NSAIDs and } \\
\text { prednisone }\end{array}$ & $\begin{array}{l}\text { Jaundice with ALT } 448 \\
\mathrm{U} / \mathrm{L}, \mathrm{AST} 1100 \mathrm{U} / \mathrm{L} \text { and } \\
\text { total bilirubin } 16.6 \\
\mathrm{mg} / \mathrm{dL}\end{array}$ & $\begin{array}{l}\text { After 3rd } \\
\text { dose of IFX }\end{array}$ & $\begin{array}{l}\text { Acute drug-induced } \\
\text { liver injury with } \\
\text { positive serum ANA, } \\
\text { and IgG, IgM and IgA } \\
\text { anti-dsDNA antibodies }\end{array}$ & Core liver biopsy & $\begin{array}{l}\text { Methyl- } \\
\text { prednisolone } \\
\text { IFX discontinued }\end{array}$ \\
\hline (197) & $\begin{array}{l}\text { HLA- } \\
\text { B27- } \\
\text { positive } \\
\text { AS }\end{array}$ & $\begin{array}{l}\text { IFX with } \\
\text { previous } \\
\text { MTX and } \\
\text { NSAIDs }\end{array}$ & $\begin{array}{l}\text { Persistently elevated } \\
\text { aminotransferase levels } \\
\text { with AST } 177 \mathrm{IU} / \mathrm{L} \text { and } \\
\text { ALT } 412 \mathrm{IU} / \mathrm{L}\end{array}$ & $\begin{array}{l}\text { After 3rd } \\
\text { dose of IFX }\end{array}$ & $\begin{array}{l}\text { Acute drug-induced } \\
\text { liver injury with } \\
\text { positive serum ANA } \\
\text { and anti-dsDNA } \\
\text { antibodies }\end{array}$ & $\begin{array}{l}\text { Percutaneous liver } \\
\text { biopsy } \\
\text { Abnormal LFT results }\end{array}$ & $\begin{array}{l}\text { No treatment } \\
\text { IFX discontinued }\end{array}$ \\
\hline (198) & $\begin{array}{l}\text { Erosie } \\
\text { RF- } \\
\text { positive } \\
\text { anti-CCP- } \\
\text { positive } \\
\text { RA }\end{array}$ & $\begin{array}{l}\text { ETN mono- } \\
\text { therapy }\end{array}$ & $\begin{array}{l}\text { Dyspnea } \\
\text { Facial palsy, eyesight } \\
\text { deficiency }\end{array}$ & $\begin{array}{l}\text { After } 4 \text { years } \\
\text { of ETN }\end{array}$ & Neurosarcoidosis & $\begin{array}{l}\text { Cerebral MRI } \\
\text { Cerebral fluid } \\
\text { 18F-fluoride PET-CT } \\
\text { scan } \\
\text { Elevated angiotensin- } \\
\text { converting enzyme in } \\
\text { serum }\end{array}$ & $\begin{array}{l}\text { IV steroids } \\
\text { ETN } \\
\text { discontinued }\end{array}$ \\
\hline$(201)$ & AS & $\begin{array}{l}\text { IFX }+ \\
\text { NSAIDs }\end{array}$ & $\begin{array}{l}\text { Progressive dyspnea } \\
\text { Hilar adenopathy } \\
\text { Ground-glass opacities }\end{array}$ & $\begin{array}{l}\text { After } 27 \\
\text { months of } \\
\text { IFX }\end{array}$ & $\begin{array}{l}\text { Stage II thoracic } \\
\text { sarcoidosis }\end{array}$ & $\begin{array}{l}\text { Chest radiography } \\
\text { CT scan } \\
\text { Histology }\end{array}$ & $\begin{array}{l}\text { No treatment } \\
\text { IFX discontinued }\end{array}$ \\
\hline$(202)$ & $\begin{array}{l}\text { Erosive } \\
\text { RF- } \\
\text { positive } \\
\text { RA }\end{array}$ & $\begin{array}{l}\text { ETN mono- } \\
\text { therapy }\end{array}$ & $\begin{array}{l}\text { Progressive dyspnea } \\
\text { and asthenia } \\
\text { Hilar adenopathy } \\
\text { Diffuse nodular pattern }\end{array}$ & $\begin{array}{l}\text { After } 49 \\
\text { months of } \\
\text { ETN }\end{array}$ & $\begin{array}{l}\text { Pulmonary } \\
\text { granulomatosis } \\
\text { compatible with } \\
\text { sarcoidosis }\end{array}$ & $\begin{array}{l}\text { Chest radiography } \\
\text { High-resolution } \\
\text { CT scan } \\
\text { Bronchoscopy } \\
\text { Transbronchial biopsy }\end{array}$ & $\begin{array}{l}\text { Prednisone } \\
\text { ETN } \\
\text { discontinued }\end{array}$ \\
\hline (203) & $\begin{array}{l}\text { Erosive } \\
\text { RA } \\
\text { Positive } \\
\text { ANA }\end{array}$ & $\begin{array}{l}\text { ETN + MTX } \\
\text { and } \\
\text { prednisone }\end{array}$ & $\begin{array}{l}\text { Slightly elevated ALP, } \\
\gamma \text {-GTP, ALT and AST } \\
\text { Normal bilirubin and } \\
\text { LDH }\end{array}$ & $\begin{array}{l}\text { After } 4 \\
\text { months }\end{array}$ & $\begin{array}{l}\text { Granulomatous } \\
\text { hepatitis }\end{array}$ & $\begin{array}{l}\text { Abnormal LFT results } \\
\text { Liver biopsy }\end{array}$ & $\begin{array}{l}\text { Ursodiol } \\
\text { ETN } \\
\text { discontinued }\end{array}$ \\
\hline$(204)$ & AS & $\begin{array}{l}\text { ADM + } \\
\text { ibuprofen }\end{array}$ & $\begin{array}{l}\text { Elevated serum } \\
\text { creatinine level } \\
\text { Low estimated } \\
\text { glomerular filtration } \\
\text { Hilar adenopathy } \\
\end{array}$ & $\begin{array}{l}\text { After } 18 \\
\text { months of } \\
\text { ADM }\end{array}$ & $\begin{array}{l}\text { Granulomatous } \\
\text { interstitial nephritis }\end{array}$ & $\begin{array}{l}\text { Chest radiograph } \\
\text { Kidney biopsy } \\
\text { Immunohistochemistry }\end{array}$ & $\begin{array}{l}\text { Prednisone } \\
\text { ADM and } \\
\text { ibuprofen } \\
\text { discontinued }\end{array}$ \\
\hline
\end{tabular}

